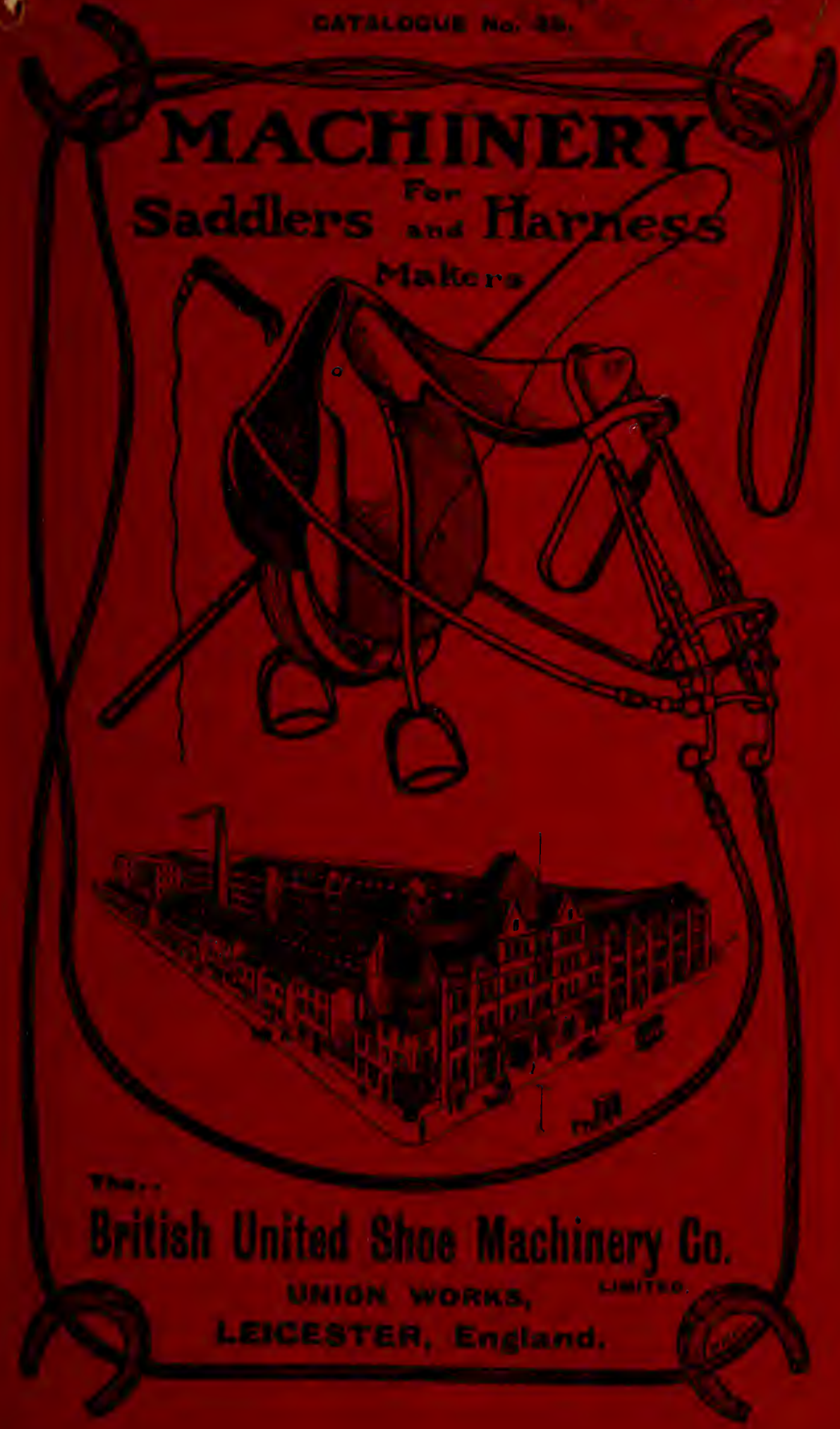




\section{Depots.}

BRISTOL.

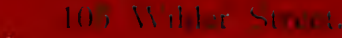

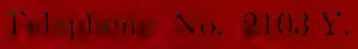

DUISLIN.

12.) youh Coul.i la d,

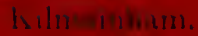

GLASTIOW

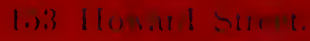

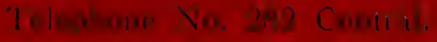

KETTERING.

I $1 \mathrm{tl} h \mathrm{~h} / \mathrm{m}$.

$$
\text { I cikplane Yis. } 9 \text { : }
$$

LEEDS.

Cis .tud fit, Nathater.

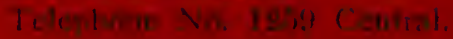

I.ONDON,

26) Cimpor Stu: I, I.C

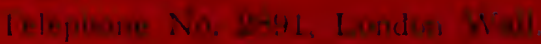

NORTHAMPTON.

dhine te n Stect.

$1, \operatorname{linh}$, N. 1:4

NORWICH.

$36 \mathrm{C} \mathrm{I}$ rete Lite

li int one Vis. 13

ZUSHDEN.

Sitzion I incrith.

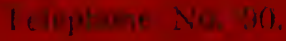

5TATEOHD.

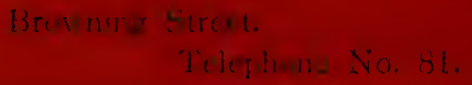

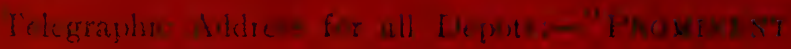




\section{MACHINERY}

-

Saddlery, Belts, Harness, Brushes, Trunks, Footballs, Bags, Braces, Purses, Horse Clothing,

$$
\text { Cycle Saddles, }
$$

$$
\text { - Also for - }
$$

Leather and Cloth Work for Road and Railway Carriages, Motor Cars, etc. ..

The British United Shoe Machinery, Co., Ltd., Union Works, Belgrave Road, Leicester. 


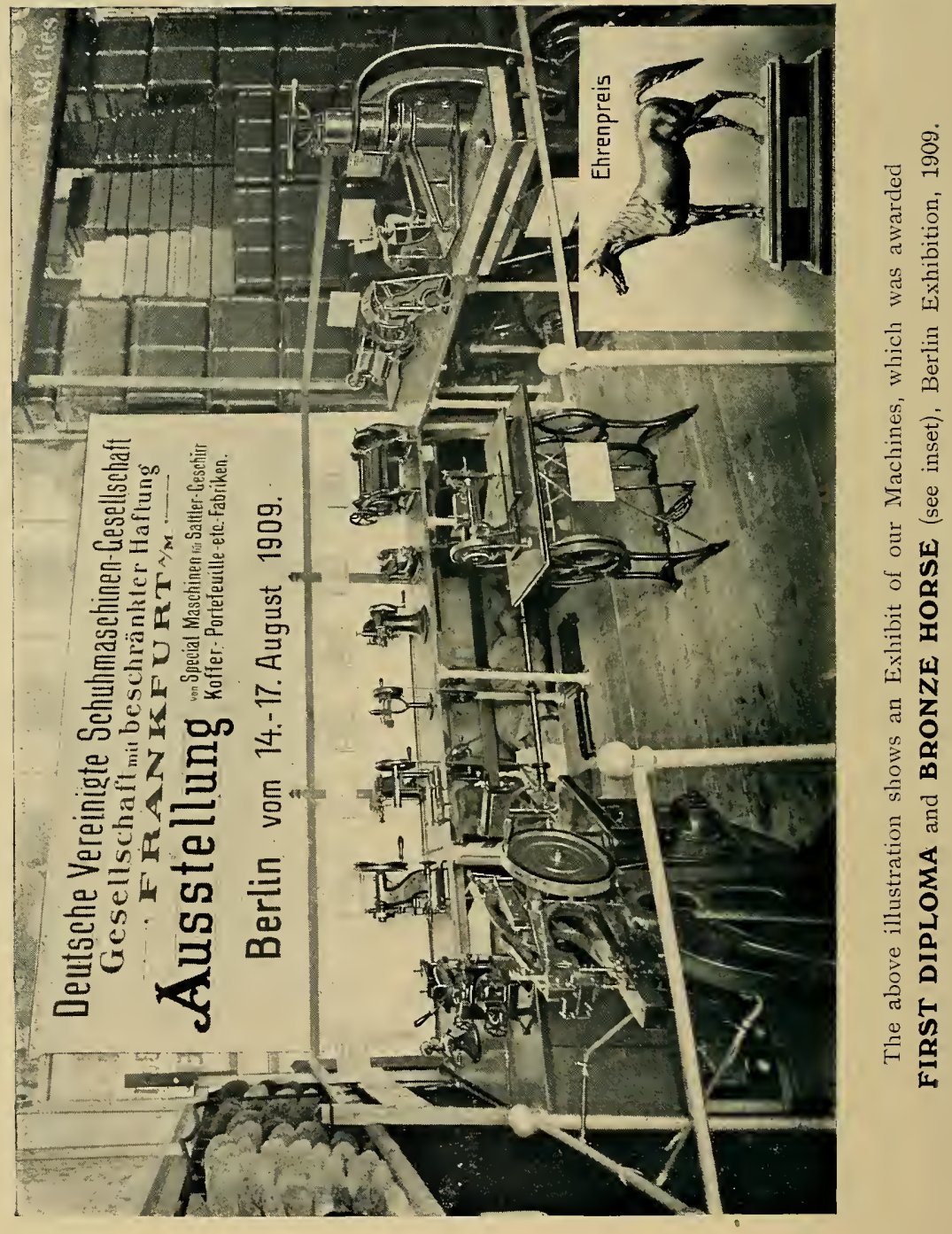




\section{TERMS.}

$x^{\circ}$

CASH OR REFERENCES must accompany orders from new. Customers.

ORDERS FOR SUNDRIES from Customers with whom we have no account MUST be accompanied by remittance to cover amount.

CARRIAGE must be paid by purchaser.

PACKING CASES, BOXES, \&c., under $2 / 6$ in value, will be charged at cost price an 1 are not returnable; above $2 ; 6$, the amount will be allowed in full, if properly ADVISED. and returned carriage paid within 15 days,

ACCOUNTS are due in 3 J days from date of invoice, less $2 \frac{1}{2} \%$, unless specially quoted otherwise.

REMITTANCES should be made by CROssed CHEgues or Postal Orders, payable at Leicester.

OVERDUE ACCOUNTS may be charged with interest at the rate of $5 \%$ per annum.

EXPORT ORDERS should be sent to. HEAD OFFICE; LEICESTER, accompanied by forwarding instructions and draft on a London Bank for the amount, or, we shall be glad to pass the bills of. lading, policy of insurance, etc.,. through a bank for collection. The cost of cases, packing. and delivery, F.O.B., is about $5 \%$ on net amount of invoice.

NOTICE.-Prices are Subject to Alteration without Notice. 


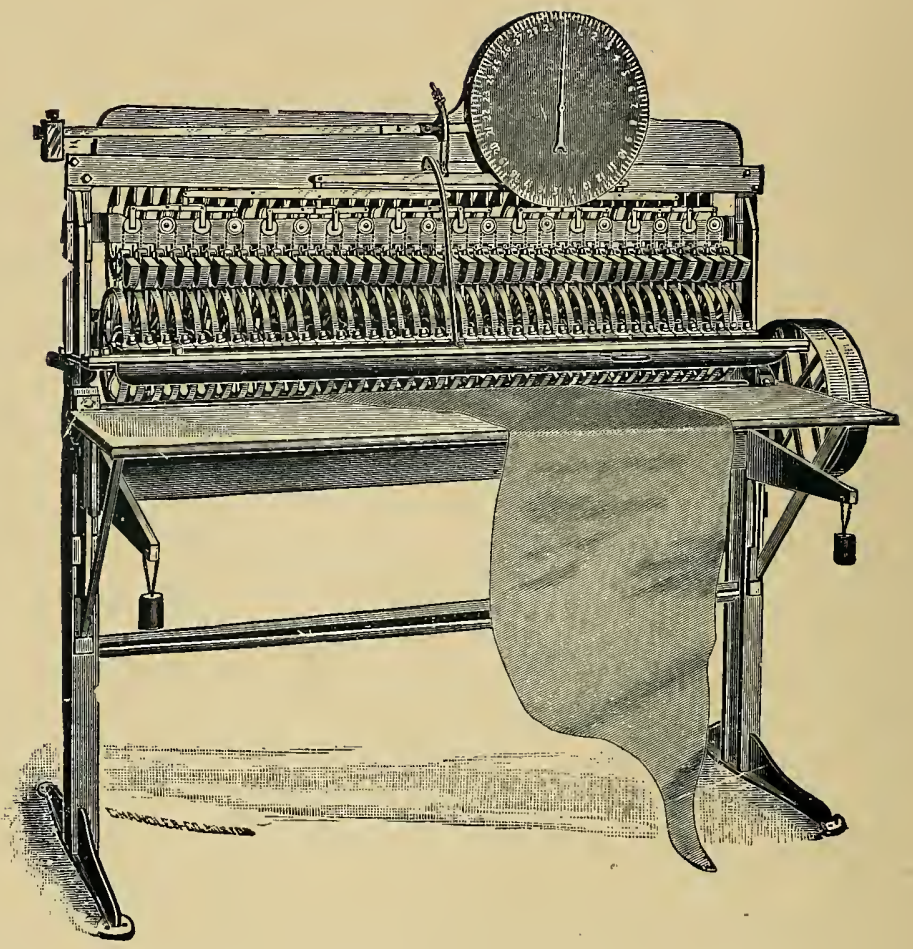

\section{Leather Measuring Machine.}

FOR measuring the superficial area of whole skins. The parts of the machine are strongly made and perfectly balanced. The machine is extremely sensitive, and accurately measures skins of any irregular shape, the total measurement being registered on the dial which is graduated with both English and Metric measurements. The machine is readily adjusted for skins of different thicknesses.
Made in four sizes, viz. $-50^{\prime \prime}$
$72^{\prime \prime}$
$84^{\prime \prime}$
$108^{\prime \prime}$

Prices on Application.

Receiving Pulley, $16^{\mu} \times 2^{4 \prime}$ runs at 65 revolutions per minute.

$\begin{array}{ccccc}\text { Belt. } & \text { Net Weight. } & \text { Gross Weight. } & \text { Floor Space. } & \text { Height. } \\ 2^{\prime \prime} & 1,232 \mathrm{lbs} . & 1,624 \mathrm{lbs} . & 88^{\prime \prime} \times 40^{\prime \prime} & 84^{\prime \prime}\end{array}$

These particulars are for the 72 " Machine. 


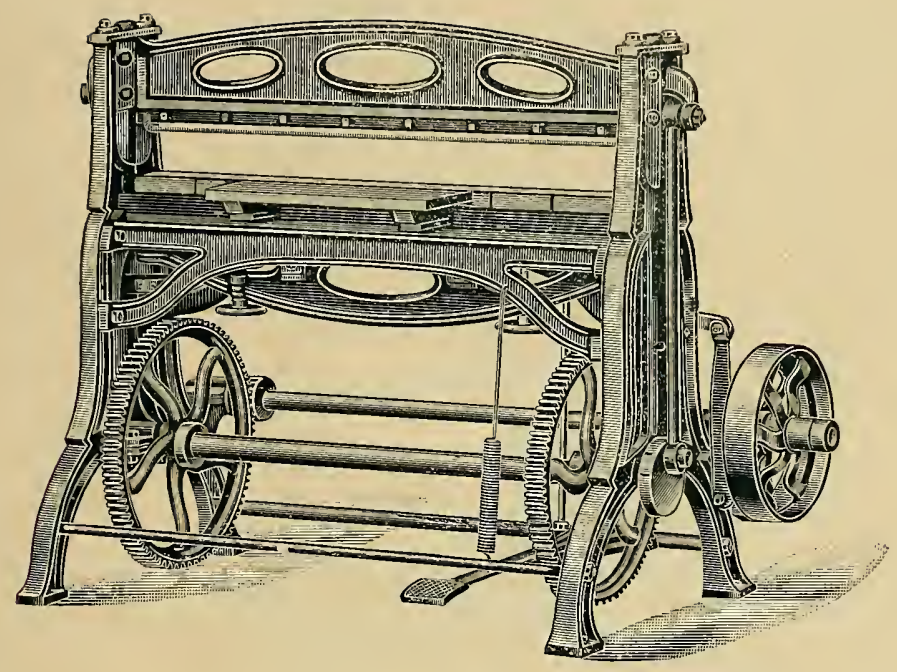

\section{Ranging Machines.}

THE knife of each machine cuts upon a sectional wood block which may be adjusted both laterally and vertically to take up any wear in the block and knife. The machines are used for cutting leather, leather board, etc., into strips of any width.

Made in two sizes, viz. $-50^{\prime \prime}$ and $78^{\prime \prime}$.

Prices on Application.

Receiving Pulley $16^{\prime \prime} \times 4^{\prime \prime}$ runs at 475 revolutions per minute.

$\begin{array}{cccccc}\text { Machine. } & \text { Belt. } & \text { Net Weight. } & \text { Gross Weight. } & \text { Floor Space. } & \text { Height. } \\ 52^{\prime \prime} & 3^{\prime \prime} & 1,000 & 1,250 & 68^{\prime \prime} \times 36^{\prime \prime} & 54^{\prime \prime} \\ 78^{\prime \prime} & 3^{\prime \prime} & 1,347 & 1,500 & 100^{\prime \prime} \times 36^{\prime \prime} & 54^{\prime \prime}\end{array}$




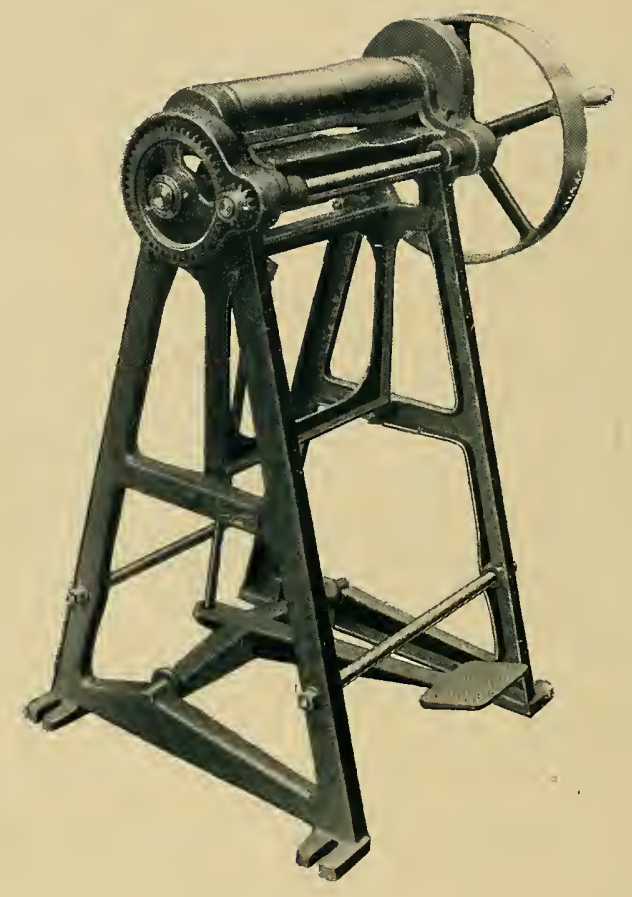

\section{Leather Rollers (Model H).}

HE rolls are parallel for part of their length and at one end are convex andl
concave respectively, so that pieces of leather may be rolled flat or moulded as required. The pressure is applied by a foot lever, and the rollers. are driven by belt power, while a handle, fixed in the pulley, allows of them being worked by hand.

$$
\text { Price } \quad \ldots \quad \$ 7 \quad 0 \quad 0
$$

Receiving Pulley $14^{\prime \prime} \times 2_{1}^{1 / \prime}$ runs at 240 revolutions per minute.

$\begin{array}{ccccc}\text { Belt. } & \text { Net Weight. } & \text { Gross Weisht. } & \text { Floor Space. } & \text { Heisht. } \\ 2^{\prime \prime} & 207 \mathrm{lbs} . & 320 \mathrm{lbs} . & 28^{\prime \prime} \times 26^{\prime \prime} & 39^{\prime \prime}\end{array}$




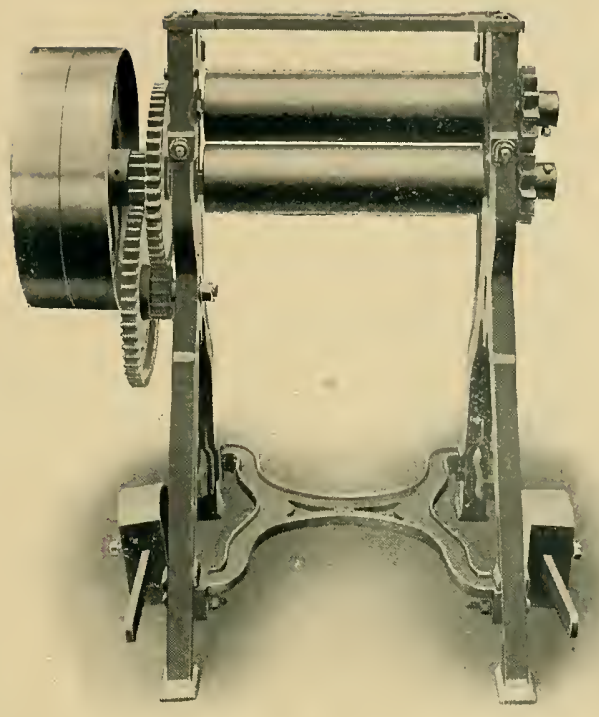

No. 2 Leather Rollers.

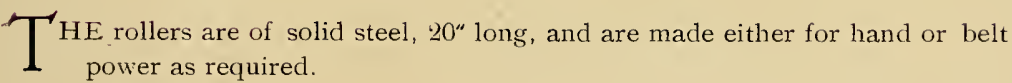

For rolling football leather, the lower roll is specially cut which ensures the leather being perfectly rolled and consolidated.

Price, for hand power, for football leather, $\$ 11 \quad 10 \quad 0$

Price, for belt power, for foottall leather, \&12 00

Receiving pulley, $18^{\prime \prime} \times 3^{\prime \prime}$, runs at 120 revolu'ions per minute.
Belt.
Nec weight.
Gross weight.
Flicor space.
$35^{\prime \prime} \times 3 C^{\prime \prime}$
Height.
753 lbs.
$48^{\prime \prime}$ 


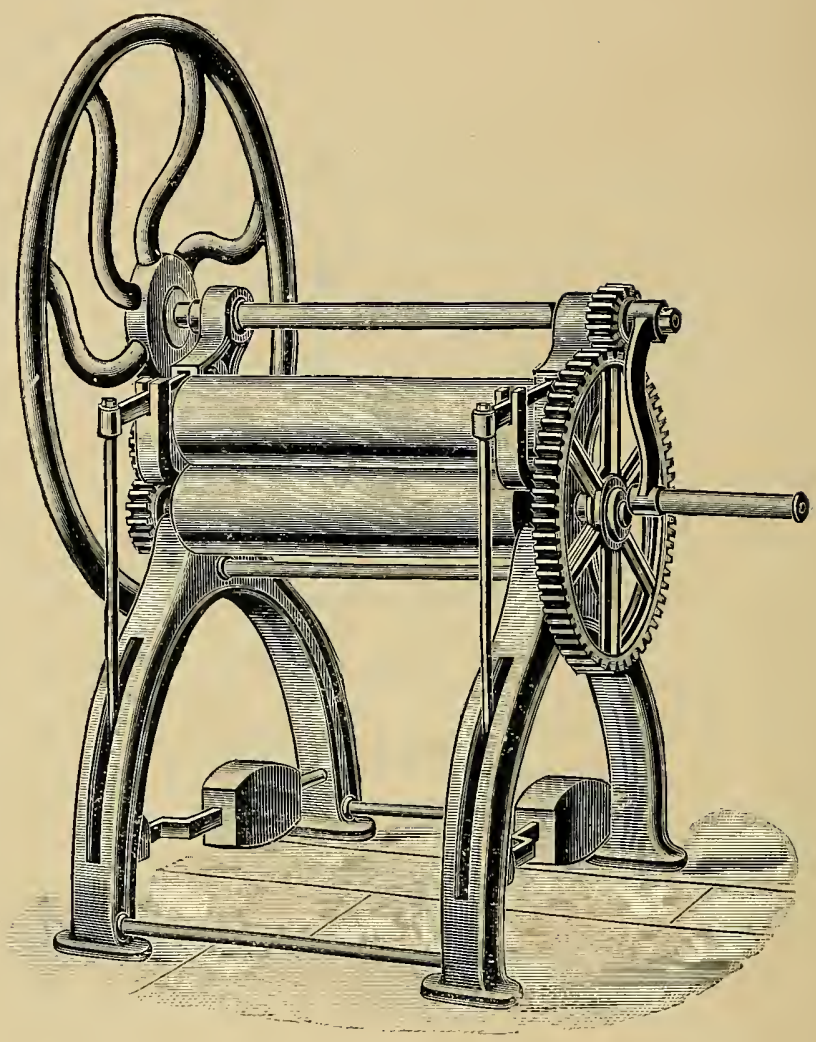

\section{No. 5 Leather Rollers.} $\prod \begin{gathered}\text { HE strong standards and rollers admit of a heary pressure being applied to } \\ \text { the leather. The steel rollers are } 28^{\prime \prime} \text { long and will roll pieces of leather }\end{gathered}$ up to this width.

The illustration slows a machine arranged to be worked by hand; they are also made with pulleys for power driving

$$
\begin{array}{cccccc}
\text { Price, for hand power } & \ldots & £ 20 & \mathbf{0} & \mathbf{0} \\
\text { " } " \text { belt } " & \ldots & £ 21 & \mathbf{0} & \mathbf{0}
\end{array}
$$

\begin{tabular}{|c|c|c|c|}
\hline $2 \frac{1}{2} "$ & $\begin{array}{l}\text { Net weigh: } \\
1088 \text { lbs }\end{array}$ & $\begin{array}{l}\text { Gross weight. } \\
1247 \text { lbs. }\end{array}$ & $\begin{array}{c}\text { Floor space. } \\
64^{\prime \prime} \times 36^{\prime \prime}\end{array}$ \\
\hline
\end{tabular}

Receiving f ulley, $18^{\prime \prime} \times 33^{\prime \prime}$, runs at 120 revolutions per minutes. 


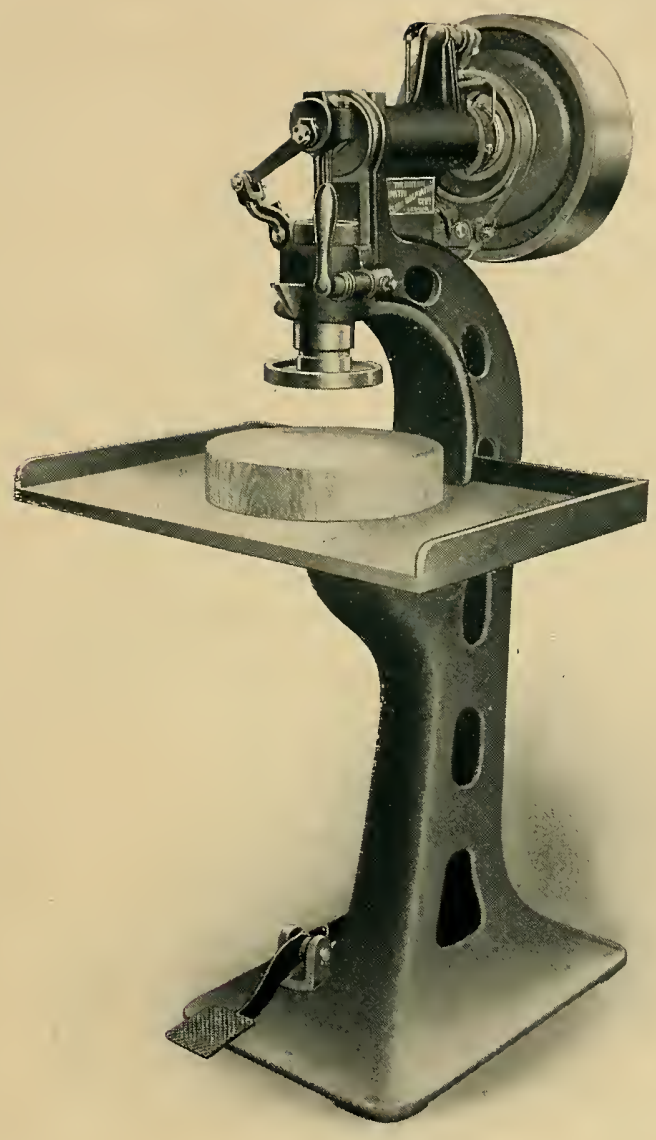

\section{No. 2 Rapid Cutting Press.}

A heavier driving wheel and re-designed driving arrangement have increased the value of this press to the manufacturer by at least 25 per cent. The speed has been increased, and its freedom from repeating makes it a safe press to use. For cutting small pieces of leather of any shape from offal or good stock the press has no equal for rapidity of working and ease of manipulation.

The machine is supplied to be operated by a foot lever, as illustrated, or in place of the foot lever, a hand lever can be provided. Some manufacturers prefer the latter on account of the additional safety to the operator.

$$
\begin{array}{llllll}
\text { Price } & \ldots & \ldots & \$ 17 & \mathbf{1 0} & \mathbf{0}
\end{array}
$$

Receiving pulley; $16^{\prime \prime} \times 4_{2}^{\frac{1}{2}}$, runs at 350 revolutions per minute.

$\begin{array}{ccccc}\text { Belt. } & \text { Net weight. } & \text { Gross weight. } & \text { Floor space. } & \text { Height. } \\ 4^{\prime \prime} & 604 \text { lbs. } & 720 \text { lbs. } & 31^{\prime \prime} \times 34^{\prime \prime} & 64^{\prime \prime}\end{array}$




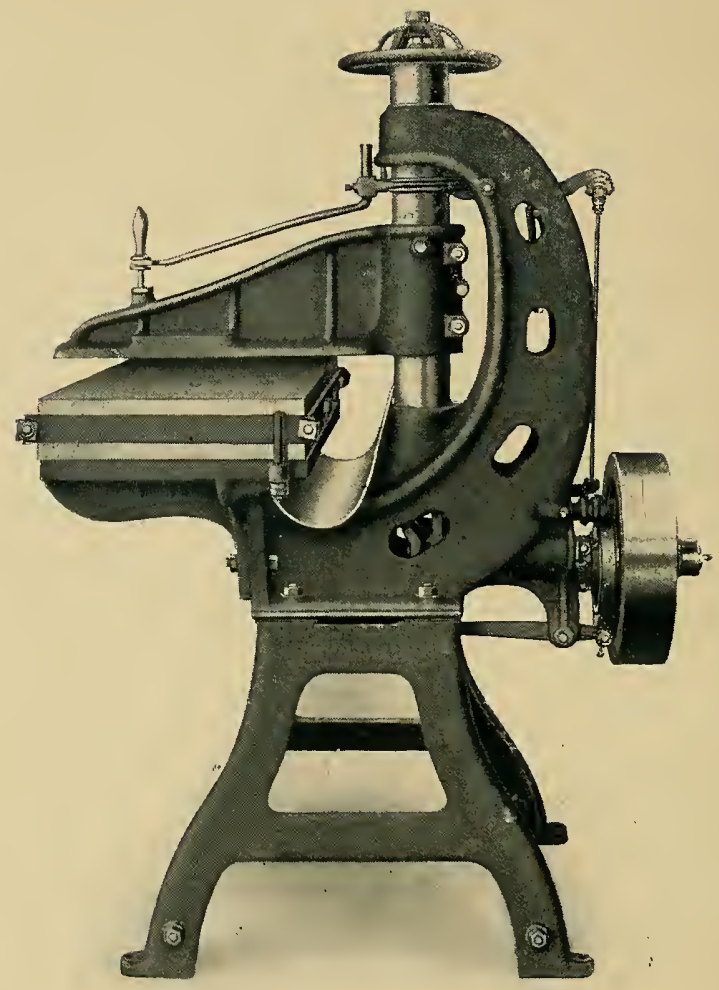

\section{No. 3 Ideal Clicking Press.}

TN place of the usual bed or platen, the Ideal Press is provided with a swing beam or arm, which is swung to either side while the knife is placed on the leather, and is afterwards brought over the knife when, on depressing the handle, the driving motion is put into gear, the swing beam makes one stroke and then comes to rest. The advantages of this arrangement are:-Safety to the operator, and the better placing of the knives on the leather. At the present time there are over 5,000 of these Presses in use, doing work which, previous to its introduction, was done by hand. For cutting purses, tool bays, and any other shapes. this machine has no equal for rapidity and accuracy.

$$
\begin{array}{llllll}
\text { Price } & \ldots & \ldots & £ 25 & 0 & 0
\end{array}
$$

Receiving pulley, $16^{\prime \prime} \times 4^{\prime \prime}$, runs at 350 revolutions per minute.

$\begin{array}{ccccc}\text { Belt. } & \text { Net weight. } & \text { Gross weight. } & \text { Floor space. } & \text { Height. } \\ 4^{\prime \prime} & 1350 \mathrm{lbs} . & 1540 \mathrm{lbs} . & 39^{*} \times 50^{*} & 72^{\prime \prime}\end{array}$




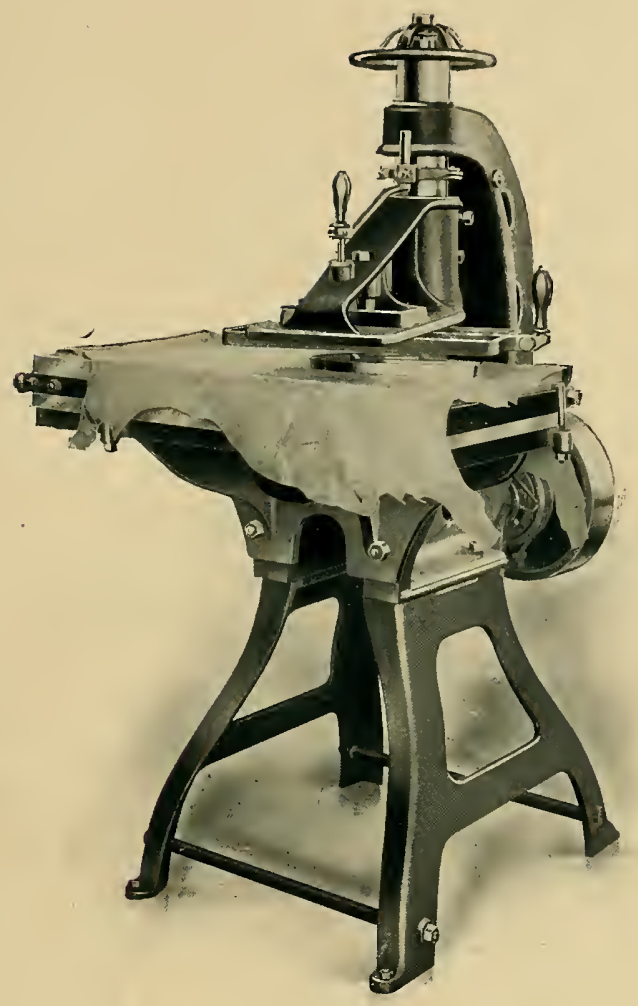

\section{No. 3 Ideal Clicking Press.}

\section{With Cover-all Swing Beam.}

$\mathrm{S}$

OMETHMES, when using a large knife, if it is placed at an angle with the edge of the block, the regular swing beam does not cover it properly. To overcome this difficulty, the Cover-all Swing Beam has been devised. This consists of a swing beam, like the regular swing beam, but having attached to it a swing plate which may be adjusted to corer the knife at any angle. Tho cover plate is readily adjusted, and the press is operated with practically the same facility as the regular Ideal Press. The press is used extensively for cutting football sections, cycle tool bays, and other shapes of similar size.

$$
\begin{array}{llllll}
\text { Price } & \ldots & \ldots & \$ 27 & \mathbf{1 0} & \mathbf{0}
\end{array}
$$

Receiving pulley, $16 " \mathrm{x} 4^{\prime \prime}$. runs at 350 revolutions per minute.

$\begin{array}{ccccc}\text { Belt. } & \text { Net weight. } & \text { Gross weis ht. } & \text { Floor space. } & \text { Height. } \\ t^{\prime \prime} & 1350 \mathrm{lbs} . & 1540 \mathrm{lbs} . & 39^{\prime \prime} \mathrm{x} 50^{\prime \prime} & 72^{\prime \prime}\end{array}$


BRITISH UNITED

SHOE MACHINERY Co., Ltd.,

LEICESTER.

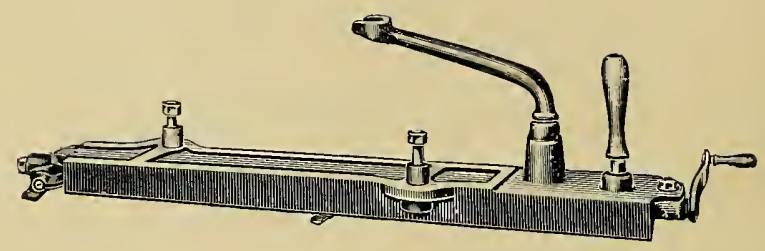

\section{Ideal Block Planing Attachment.}

TN order to obtain the best results from the Ideal Clicking Press, or any other press using a wood cutting block, it is necessary to keep the surface of the block level, and the Ideal Block Planing Attachment is designed for this purpose, It is attached to the swing beam of the Press, which is swung backwards and forwards, the knife being automatically fed so that it cuts in an advanced position at each stroke. If not too badly worn, a block may be levelled by this means in half an hour.

$$
\text { Price } \quad \ldots \quad £ 5 \quad 0 \quad 0
$$




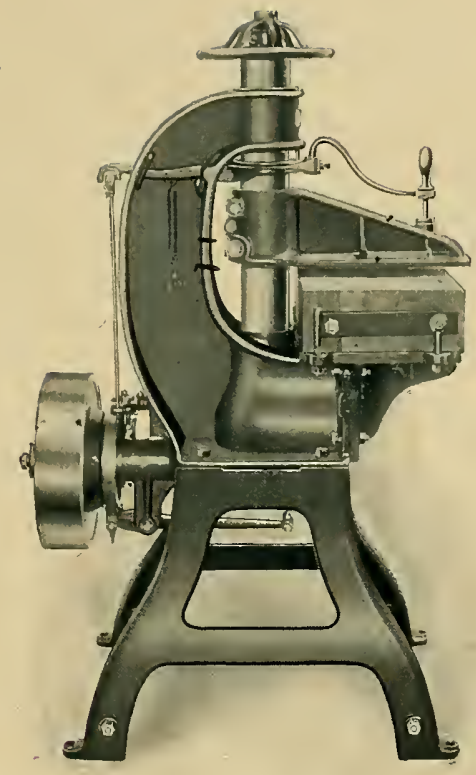

\section{The Magic Press.}

TN general design and principle of working the Magic Press is the same as the 1 Ideal, the difference between them being that the Magic is smaller. The press is used for cutting small pieces of leather of any shape, in doing which it works very rapidly. Many of these presses are being operated by boys and girls, the height of the block keing arranged with a riew to the employment of youthful labour.

$$
\text { Frice } \quad \ldots \quad \ldots \quad £ 20 \quad 0 \quad 0
$$

Receivins yulley, $16 " x 4^{\prime \prime}$, runs at 350 revolutions per minute.

$\begin{array}{ccccc}\text { Belt. } & \text { Net weight. } & \text { Gross weight. } & \text { Floor space. } & \text { Height. } \\ 4^{\prime \prime} & 920 \text { lbs. } & 1100 \text { lbs. } & 27^{\prime \prime} \times 36^{\prime \prime} & 60^{\prime \prime}\end{array}$




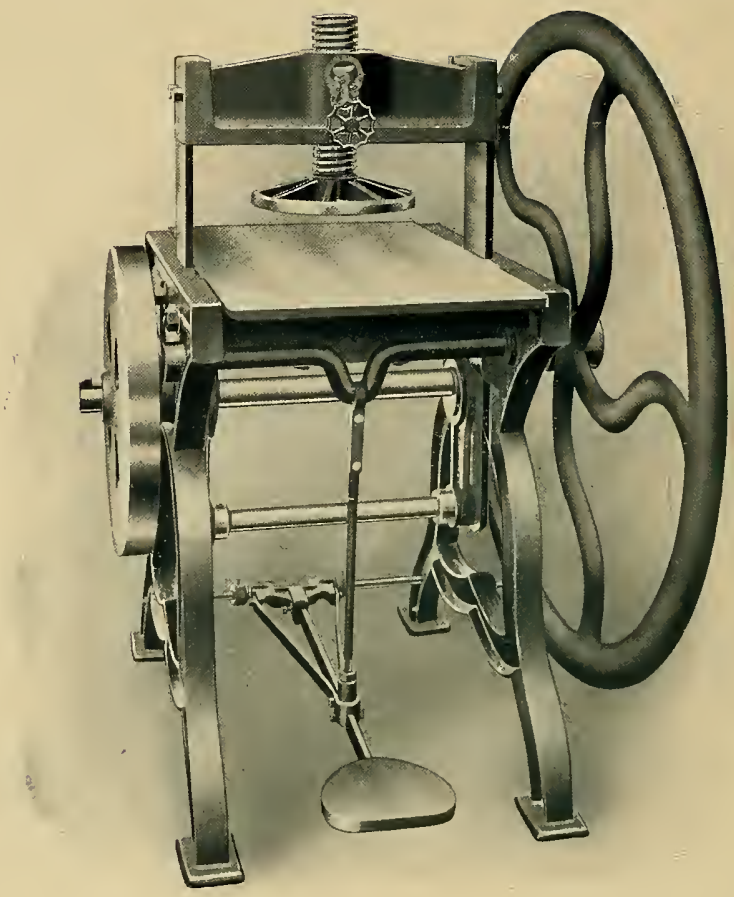

\section{A Press.}

HE Buffer or platen is $11^{\prime \prime}$ in diameter and is adjustable in leight so that
cutting blocks and cutters of different thicknesses and depths may be used.

The uprights admit of pieces of leather $20^{\prime \prime}$ wide passing between them.

$\begin{array}{lllrll}\text { Price with treadle or for telt fower } & \ldots & \ldots & £ 12 & \mathbf{0} & \mathbf{0} \\ \text { Price with both treadle and pulleys } & \ldots & \ldots & \mathbf{1 3} & \mathbf{0} & \mathbf{0} \\ \text { Sliding tray with handles, extra } & \ldots & \ldots & \mathbf{0} & \mathbf{7} & \mathbf{6}\end{array}$

Receiving pulley $12^{\prime \prime} \times 3^{\prime \prime}$ runs at 225 revolutions per minute.
Belt,
$23 /$
Net weight,
Gross weight.
Floor space,
Height. 1064 lbs.
1298 lbs.
$45^{\prime \prime} \times 33^{\prime \prime}$
$52^{\circ}$ 


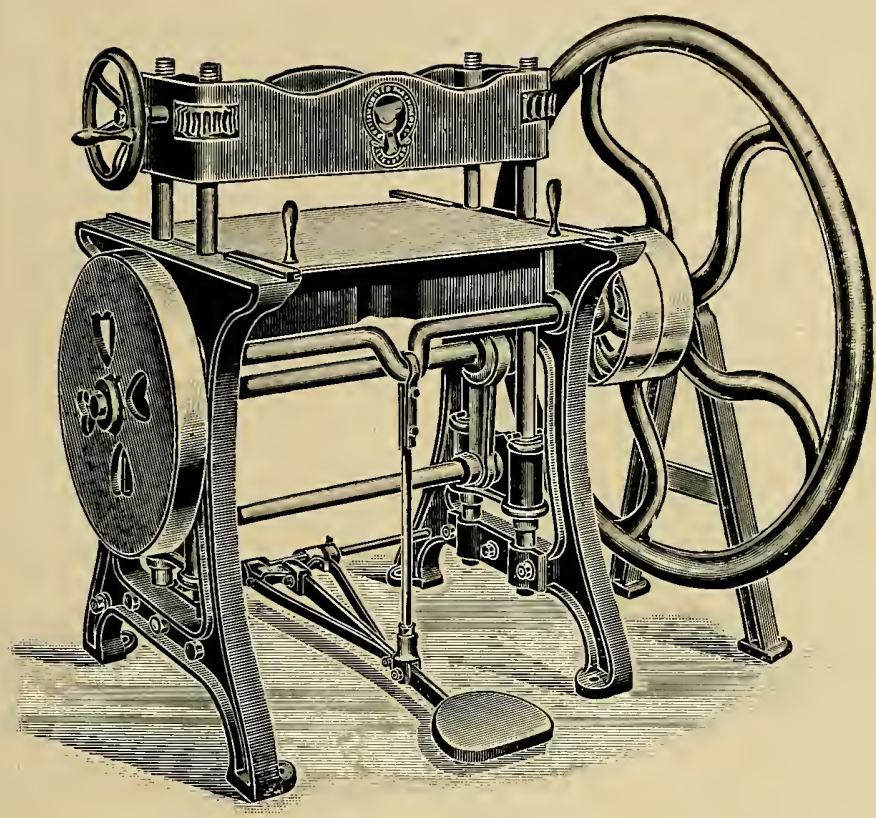

\section{Four-Pillar Box-Bed Presses.}

HE style of platen adopted in these presses allows of much larger cutters
being used than with the Buffer Press.

The pressure is distributed evenly throughout the platen by means of the four steel rods or pillars which are reciprocated by an eccentric shaft.

The presses are very strongly made, and the height of the platen is adjustable.

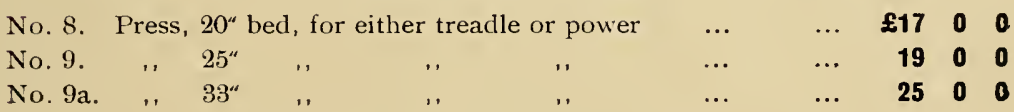

If made for both treadle and power, $\$ 1$ extra each.

A sliding tray is included in the above prices.

Receivin:s fulley, $12^{\prime \prime} \times 3$, runs at 2.25 rcvo'utions per minute.

$\begin{array}{ccccc}\text { No. } & \text { Net weight. } & \text { Gross weight. } & \text { Floor space. } & \text { Heisht. } \\ 8 & 120 \pm \text { lbs. } & 1428 \text { lbs. } & 48^{\prime \prime} \times 48^{\prime \prime} & 48^{\prime \prime} \\ 9 & 1281 \text { lbs. } & 1505 \text { lbs. } & 54^{\prime \prime} \times 48^{\prime \prime} & 48^{\prime \prime} \\ 9 \text { a } & 1596 \mathrm{lbs} . & 1848 \mathrm{lbs} . & 62^{\prime \prime} \times 48^{\prime \prime} & 48^{\prime \prime}\end{array}$




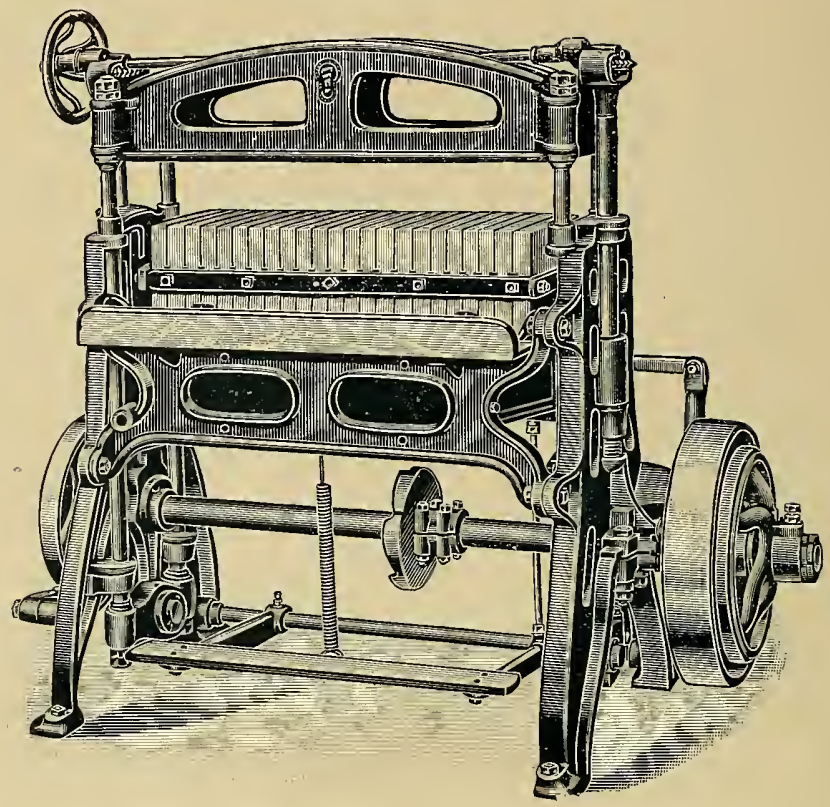

\section{Revolution Presses.}

WhEN large quantities of leather have to be cut up by means of a press, a Revolution Press is the most economical press to use. It is more speedy and more economical in the power required to drive it.

One reason of its greater out-turn is, that the whole block may be covered with a side or other large piece of leather and the press knife is used from one end of the block to the other without it being necessary to move the leather.

These presses are used for cutting out cycle saddles, cycle tool bags, gear cases, and they are now used in most wholesale saddlery and harness factories, and in railway workshops where leather is used.

\begin{tabular}{|c|c|c|c|}
\hline $3 \mathrm{ft}$. machine & $\ldots$ & $£ 37$ & 00 \\
\hline 4 & $\ldots$ & 42 & 0 \\
\hline , , & 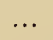 & 47 & 0 \\
\hline ,. & & 52 & 0 \\
\hline
\end{tabular}

Receiving pulley for $3 \mathrm{ft}$. and $4 \mathrm{ft}$. Presses, $24^{\prime \prime} \mathrm{x} 4^{\frac{1}{4}}$, runs at 225 revolutions per minute.

Receiving pulley for $5 \mathrm{ft}$. and $7 \mathrm{ft}$. Presses, $27^{\prime \prime} \times 4^{\frac{11}{2}}$, runs at 225 revolutions per minute.

$\begin{array}{llllll}\text { Press. } & \text { Belt. } & \text { Net weight. } & \text { Gross weight. } & \text { Floor space. } & \text { Height. } \\ 3 \mathrm{ft} . & 4^{\prime \prime} & 2562 \mathrm{lbs} . & 2590 \mathrm{lbs} . & 48^{\prime \prime} \times 70^{\prime \prime} & 68^{\prime \prime} \\ 4 \mathrm{ft} . & 4^{\prime \prime} & 2626 \mathrm{lbs} . & 2660 \mathrm{lbs} . & 48^{\prime \prime} \times 82^{\prime \prime} & 71^{\prime \prime} \\ 5 \mathrm{ft} . & 4^{\prime \prime} & 3506 \mathrm{lbs} . & 3566 \mathrm{lbs} . & 50^{\prime \prime} \times 99^{\prime \prime} & 72^{\prime \prime} \\ 7 \mathrm{ft} . & 4^{\prime \prime} & 4116 \mathrm{lbs} . & 4172 \mathrm{lbs} . & 50^{\prime \prime} \times 123^{\prime \prime} & 74^{\prime \prime}\end{array}$




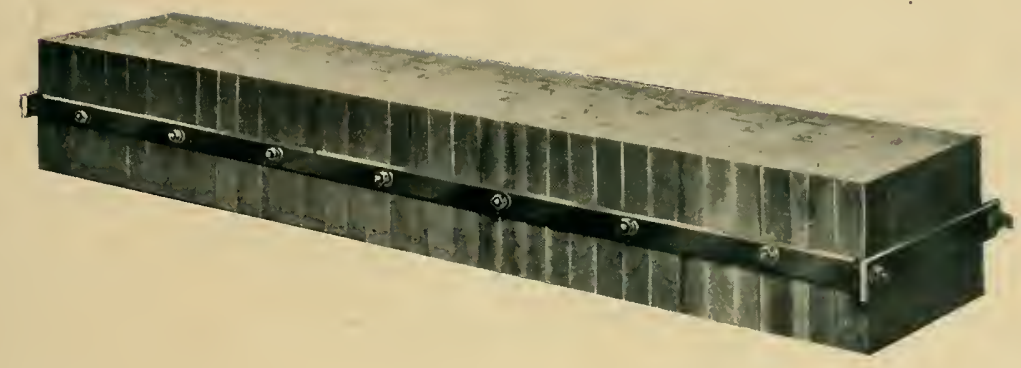

\section{Sectional Press Blocks.}

\section{For Revolution Presses.}

$\mathrm{O}$

NLY the finest quality of American Rock Maple Sectional Press Blocks are stocked. The sections are glued together under great pressure, and each transverse joint is grooved and tongued so that each block is like one solid piece of timber, but is inflnitely superior in that it will not split or warp.

$\begin{array}{llclc}72^{\prime \prime} \times 14^{\prime \prime} \times 10^{\prime \prime} & \ldots & \text { Banded. } & & \text { Not Banded. } \\ 52^{\prime \prime} \times 14^{\prime \prime} \times 10^{\prime \prime} & \ldots & \mathbf{5 6} /- & \ldots & \mathbf{4 4} /- \\ 48^{\prime \prime} \times 14^{\prime \prime} \times 10^{\prime \prime} & \ldots & \mathbf{3 7} /- & \ldots & \mathbf{3 1} /- \\ 40^{\prime \prime} \times 14^{\prime \prime} \times 10^{\prime \prime} & \ldots & \mathbf{3 2} /- & \ldots & \mathbf{2 9} /- \\ 28^{\prime \prime} \times 14^{\prime \prime} \times 10^{\prime \prime} & \ldots & \mathbf{2 2} /- & \ldots & \mathbf{2 5} /- \\ 24^{\prime \prime} \times 14^{\prime \prime} \times 10^{\prime \prime} & \ldots & \mathbf{1 9} /- & \ldots & \mathbf{1 6} / \mathbf{6} \\ 40^{\prime \prime} \times 14^{\prime \prime} \times 6^{\prime \prime} & \ldots & \mathbf{2 3} /- & \ldots & \mathbf{1 6} /-\end{array}$

When sent by rail blocks should be banded. Half-price allowed for complete sets of bands and bolts, if returned in good condition, carriage paid. 


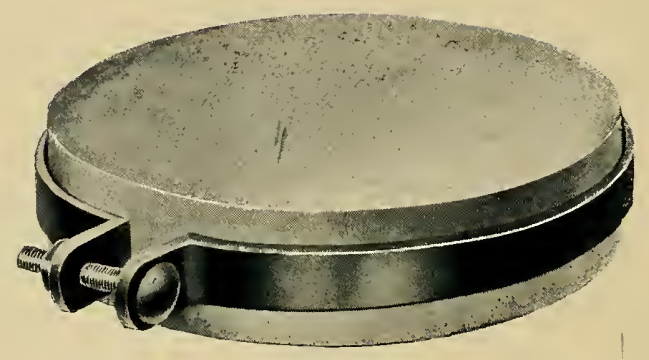

\section{Circular Press Blocks.}

IRCULAR Blocks are generally used with the No. 2 Rapid Cutting Press. $\smile$ the A1 Buffer Press, and each of the Four-pillar Box-bed Presses. They are also used for cutting out pieces of leather with handled cutters and a mallet. They are made in various sizes, the most usual size being $14^{\prime \prime}$ diameter by $3^{\text {* }}$ deep.

\begin{tabular}{|c|c|c|c|c|c|c|c|c|c|}
\hline Diameter, & & Thickness. & & Per dozen. & Diameter. & & Thickness. & & er dozen_. \\
\hline $13^{\prime \prime}$ & $\mathrm{x}$ & $3^{\prime \prime}$ & $\ldots$ & 9/- & $14^{\prime \prime}$ & $\mathrm{x}$ & $3 \frac{11}{2} "$ & $\ldots$ & $11 / 6$ \\
\hline $13 \frac{11}{2}$ & $x$ & $3^{\prime \prime}$ & $\ldots$ & $9 / 6$ & $14^{\prime \prime}$ & $\mathrm{x}$ & $4^{\prime \prime}$ & $\ldots$ & $13 /-$ \\
\hline $14^{\prime \prime}$ & $\mathrm{x}$ & $3^{\prime \prime}$ & $\ldots$ & $10 /-$ & $14^{\prime \prime}$ & $\mathrm{x}$ & $4 \frac{1}{2} "$ & $\ldots$ & $14 / 6$ \\
\hline $14 \frac{1}{2} "$ & $\mathrm{x}$ & $3^{\prime \prime}$ & $\ldots$ & $10 / 6$ & $14^{\prime \prime}$ & $x$ & $5^{\prime \prime}$ & $\cdots$ & 16 - \\
\hline $15^{\prime \prime}$ & $x$ & $3^{\prime \prime}$ & $\ldots$ & $11 /-$ & $14^{\prime \prime}$ & $x$ & 50 & $\ldots$ & $17 / 6$ \\
\hline $15 \frac{1}{2} "$ & $\mathrm{x}$ & $3^{\prime \prime}$ & $\ldots$ & 116 & $14^{\prime \prime}$ & $x$ & $6^{\prime \prime}$ & $\ldots$ & $19 /-$ \\
\hline $16^{\prime \prime}$ & $\mathrm{x}$ & $3^{\prime \prime}$ & $\ldots$ & $12 /-$ & & & & & \\
\hline
\end{tabular}

Other sizes at proportionate rates.

Iron Bands for above sizes $\quad \ldots \quad 3 / 6$ each. 


\section{Hand Cutting Boards.}

\footnotetext{
7 HE usual size for these boards is $36^{\prime \prime}$ long by $18^{\prime \prime}$ wide by 4 " thick, andisthe prices below refer to boards of these dimensions.
}

Larger boards are supplied when required.

$\begin{array}{ccc}\text { Pine Boards-Wood Clamped } & \ldots & \mathbf{1 4} \mathbf{6} \text { each } \\ , \quad,, \quad \text {-not Clamped } \ldots & \ldots & \mathbf{1 3} \mathbf{9}, " \\ \text { Lime Boards-Wood Clamped } & \ldots & \mathbf{1 5 / 6}, \\ , " \quad, \quad \text {-not Clamped } \ldots & \ldots & \mathbf{1 4 9}, "\end{array}$

Clamped Boards are always supplied unless they are ordered without clamps. 


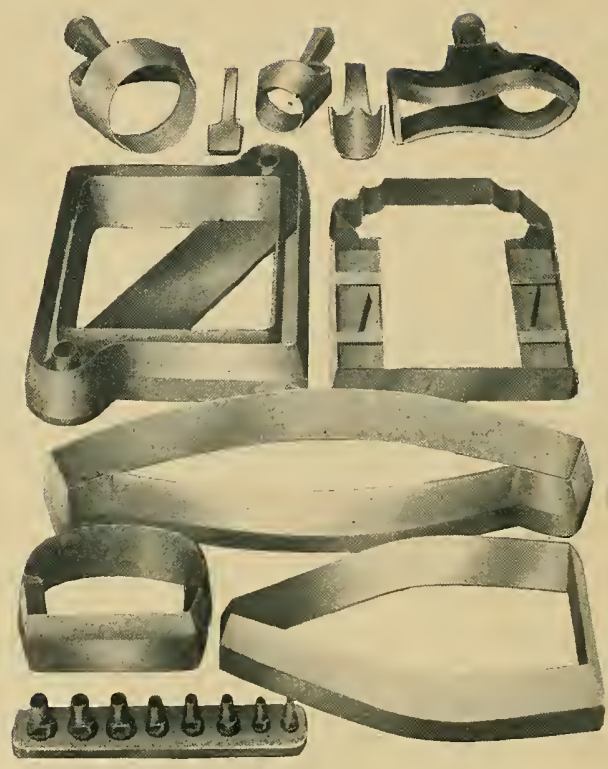

\section{Knives, Cutters and Punches.}

KIFE making is a very important branch of our business. Among the knives 1 we are constantly making, we may mention those for cutting saddle flaps, skirts and eaves, winkers, fronts, carriage pad tops, tugs, safes and crupper bodies and docks, breast plates, martingales, rein billets, hip straps, trace points, buckle chapes, accoutrements, rug straps, bag handles, purses, footballs, brace ends, washers, pump leathers, cycle saddles, tool bags, gear cases, hats, hat boxes, cap quarters and peaks ; dress collars, facings, shoulder pads, shields, and many other purposes.

Knives for straps, buckle chapes, brace encls, washers, etc., are frequently fitted with stitch prickers and punches, so that the pieces cut are pricked, punched and cut at the same time.

When required, these knives are made so that the cut piece is automatically ejected, instead of each piece having to be stripped from the prickers, punches, etc., by hand, and thus a very considerable amount of time is saved.

Knives for some of these shapes are sometimes made with handles and used together with raw hide or wooden mallets. These knives are also frequently fitted with prickers and punches.

We shall be glad to quote for any knife or punch on receipt of paper pattern of the shape it is required to cut, and we guarantee the quality and accuracy of all knives or punches we make. 


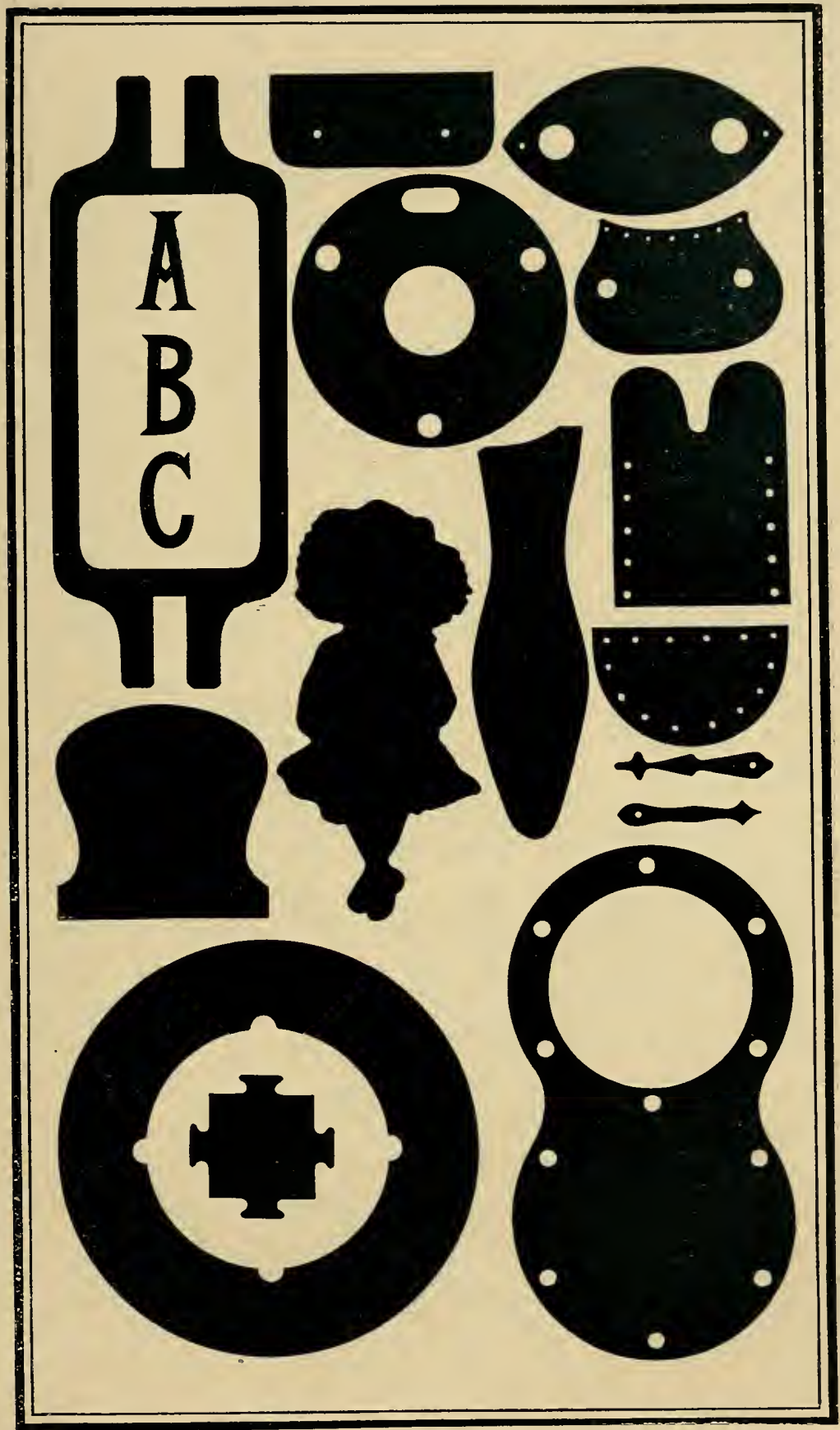

Press Knives for Fancy Leather Work. 


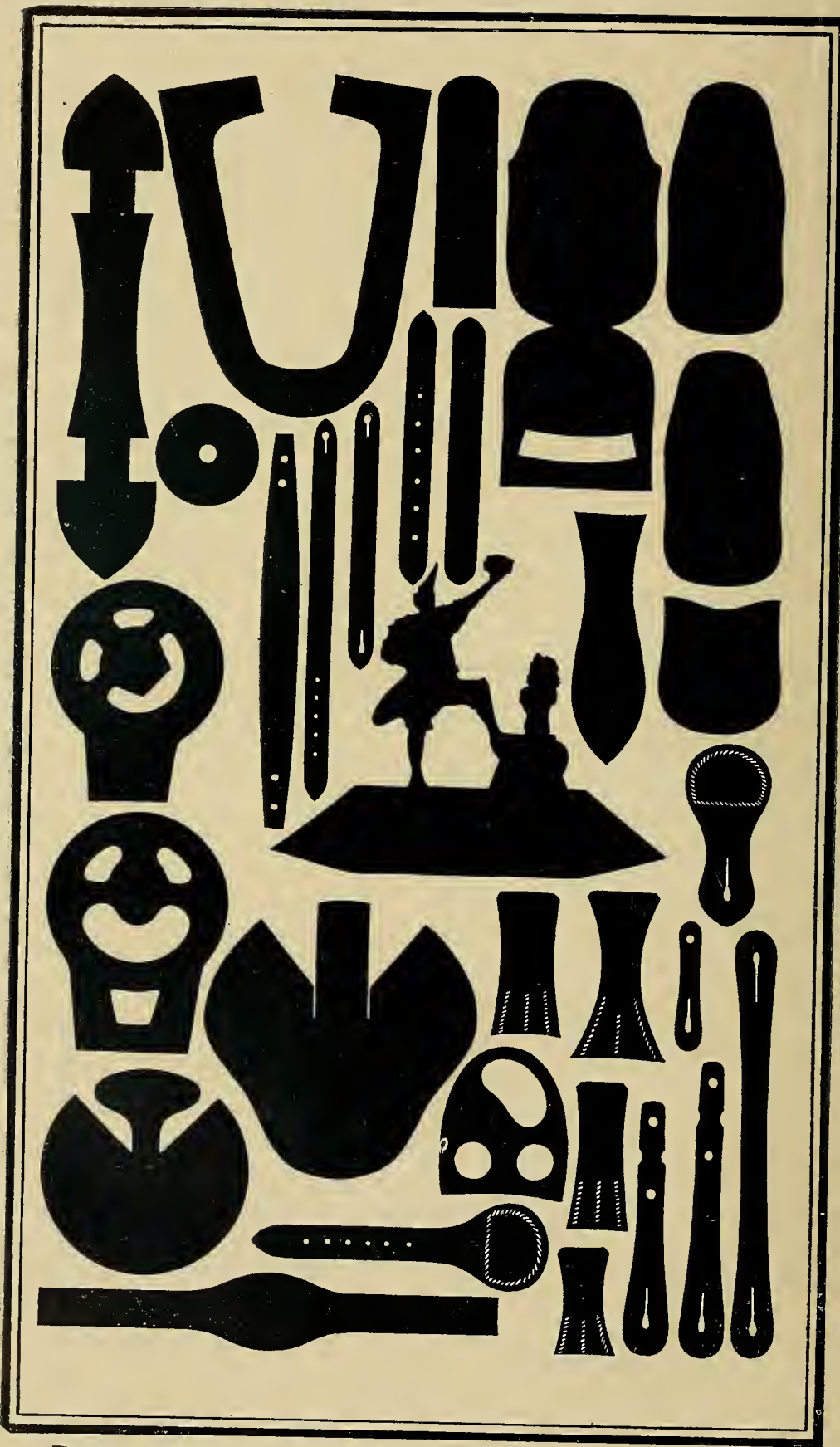

Press Knives for Fancy Leather Work. 


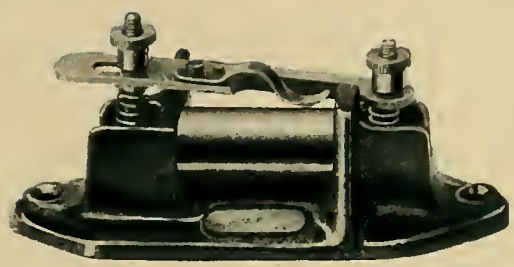

\section{Bevelling or Skiving Machine.}

入 handy little machine for skiving straight or waved edges for anyzurpose. For raised and half-round work it acts splendidly.

Price $\quad \ldots \quad 10 / 6$ each.

Extra knives, 4/- each.

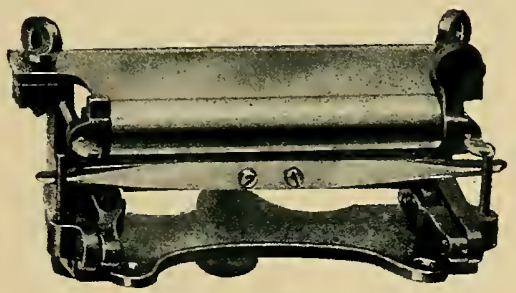

Osborne's American Splitting Machines.

THESE machines are used for the same purpose as those described on page24 , but are of a different pattern. We can strongly recommend them as. being good, reliable machines.

\begin{tabular}{|c|c|c|c|c|c|c|c|c|c|c|}
\hline $5^{\prime \prime}$ & chine & $\ldots$ & $\ldots$ & $\cdots$ & £1 & 1 & 0 & Extra & knife & $\ldots$ \\
\hline $6^{\prime \prime}$ & ." & $\cdots$ & $\ldots$ & $\ldots$ & 1 & 2 & 6 & ,. & ,. & 96 \\
\hline $7 "$ & , & $\ldots$ & $\ldots$ & $\ldots$ & 1 & 4 & 0 & ,. & ,. & $\ldots 11 / 6$ \\
\hline $8^{\prime \prime}$ & .. & $\ldots$ & $\ldots$ & $\ldots$ & 1 & 7 & 6 & .. & ,. & $\ldots 13 / 6$ \\
\hline $9^{\prime \prime}$ & ,. & $\ldots$ & $\ldots$ & $\ldots$ & 1 & 9 & 6 & ", & ." & $\ldots 156$ \\
\hline $10^{\prime \prime}$ & ,, & $\ldots$ & $\ldots$ & $\ldots$ & 1 & 13 & 6 & ., & .. & $\ldots \quad 16 / 6$ \\
\hline $12^{\prime \prime}$ & ,, & $\ldots{ }^{\circ}$ & $\ldots$ & $\ldots$ & 2 & & 0 & ., & ., & $\ldots 25 /-$ \\
\hline
\end{tabular}




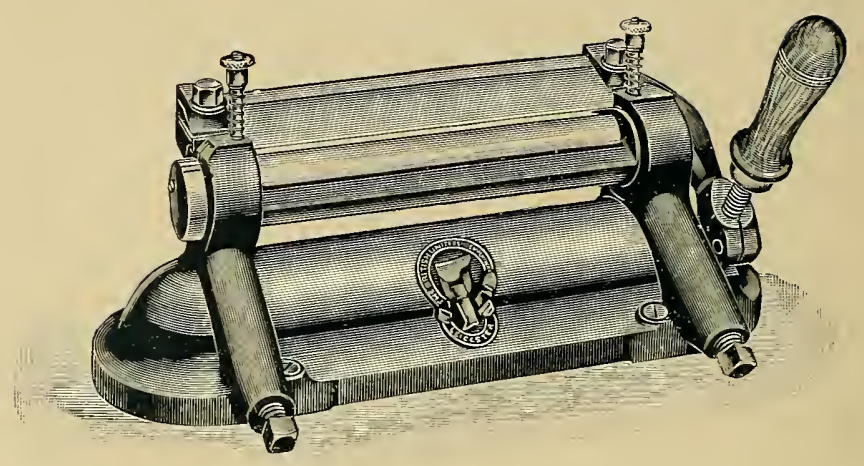

\section{Saddlers' Splitting Machines.}

$\mathrm{T}$

HE base of this machine is very substantial and does not spring when a strap or other piece of leather is being pulled through.

The handle is used to open the space between the knife and roll to admit the strap, etc., and is also adjuste 1 to regulate the thickness to which the leather is to be split.

The space between the knife and roll may also be opened by means of a treadle supplied with the machine, by using which both hands are at liberty to control the leather.

One end of the Roll Carrier is graduated to shew the thickness to which the machine is adjusted to split.

The machine is used for splitting or levelling straps, etc., and is also used for cutting tapered ends for splicing.

A guard which also keeps the leather in contact with the roll is not shewn in the illustration. It has been removed in order to shew the knife and roll more clearly.

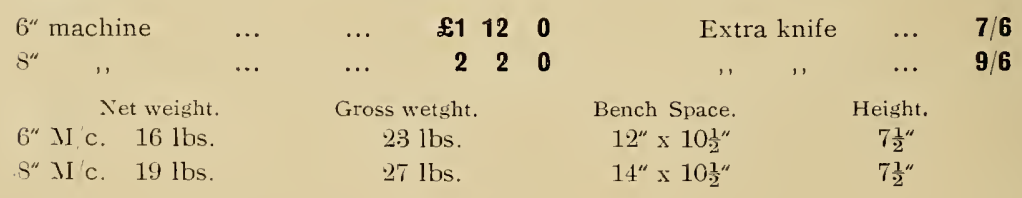




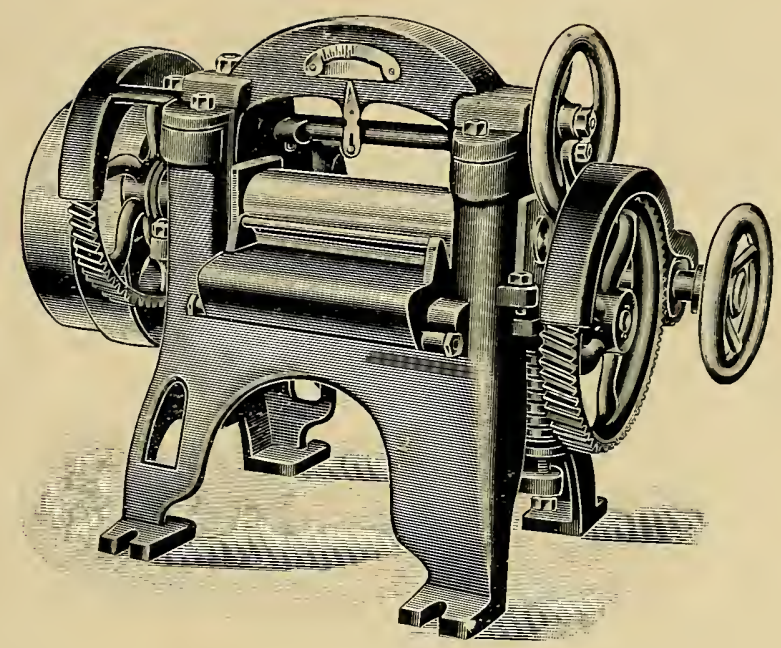

\title{
7 $\frac{1}{2}$-inch Summit Splitting Machine.
}

\begin{abstract}
入 common fault with Splitting Machines is that both the knife and frame are too light, and spring when a piece of leather is being split, the result being that the leather is not split evenly. The Summit Splitting Nachine is designed to overcome this difficulty, the frame being rery substantial and the knife being clamped so that it does not spring under any reasonable condition. An indicator is provided to show the thickness the machine is adjusted to split. The machine is usually made to be driven by belt power, but when required, is also made to be worked by hand.
\end{abstract}

$$
\text { Price } \quad \ldots \quad \$ 15 \quad 0 \quad 0
$$

Receiving pulley, $10^{\prime \prime} \times 23^{3}{ }^{\prime \prime}, 1$ uns at 240 rerolutions per minute.

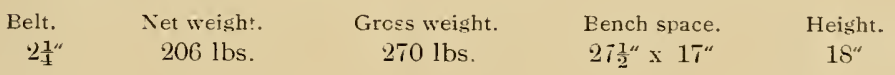


SHOE MACHINERY Co., Ltd.,

LEICESTER.

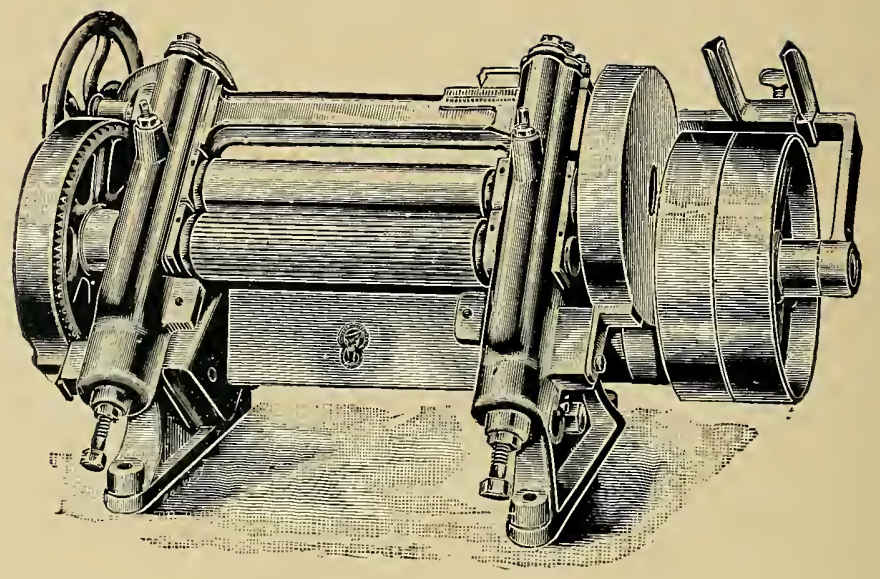

New Model Splitting Machines.

7 HE illustration shews a convenient form of Splitting Machine which is made in 3 sizes for equalizing leather of every description, harness leathers, gig and riding saddle flaps, etc., also made specially for the trunk and bag trades, and for splitting piping, bag-frame leather, etc.

The scale and pointer enable the machine to be readily adjusted to split any required thickness.

No. 1. To split up to $7^{\prime \prime}$

No. 3. To split up to $13^{\prime \prime}$

No. 4. To split up to $19^{\prime \prime}$

The above prices are for bench machines.
To work by power

$\begin{array}{lll}27 & 0 & 0 \\ 11 & 0 & 0 \\ 15 & 0 & 0\end{array}$

Receiving pulley, No. 1 machine, $9^{\prime \prime} \times 2^{\prime \prime}$ runs at 120 revolutions per minute.

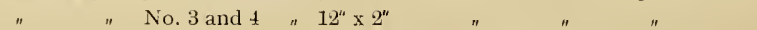

$\begin{array}{ccccc}\text { Belt. } & \text { Net weight. } & \text { Gross weight. } & \text { Bench space. } & \text { Height, } \\ \text { No. } 1^{\prime \prime} \mathrm{m} / \mathrm{c}, 2^{\prime \prime} & 99 \mathrm{lbs} . & 137 \mathrm{lbs} . & 17^{\prime \prime} \times 13^{\prime \prime} & 15^{\prime \prime} \\ \text { No. } 3 \mathrm{~m} / \mathrm{c}, 2^{\prime \prime} & 252 \mathrm{lbs} . & 322 \mathrm{lbs} . & 28^{\prime \prime} \times 15^{\prime \prime} & 18^{\prime \prime} \\ \text { No. } 4 \mathrm{~m} / \mathrm{c}, 2^{\prime \prime} & 328 \mathrm{lbs} . & 392 \mathrm{lbs} . & 40^{\prime \prime} \times 18^{\prime \prime} & 18^{\prime \prime}\end{array}$




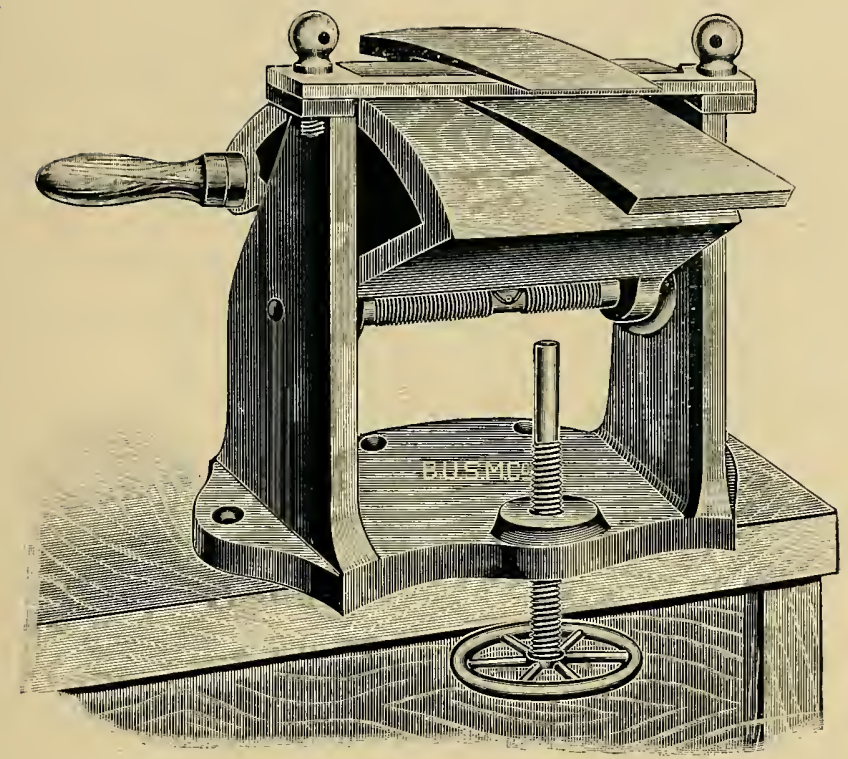

\section{Osborne's Lap Skiving Machine. Dixon's Patent.}

TOR cutting tapered ends on straps for splicing, etc. The machine may also
be used for splitting straps to a uniform thickness.

The machine is adjustable for cutting splices of various lengths, and is very easily operated.

A pressure bar, not shewn in the illustration, keess the leather in contact with the cam.

Price $\quad \ldots \quad £ 2 \mathbf{1 0} \quad 0$

$\begin{array}{lclc}\text { Net weight. } & \text { Gross waight. } & \text { Bench space. } & \text { Height. } \\ 15 \frac{1}{2} \text { lbs. } & 21 \text { lbs. } & 10 \frac{1}{2}^{\prime \prime} \times 6 \frac{1}{2}^{\prime \prime} & 8{ }_{2}^{\prime \prime}\end{array}$




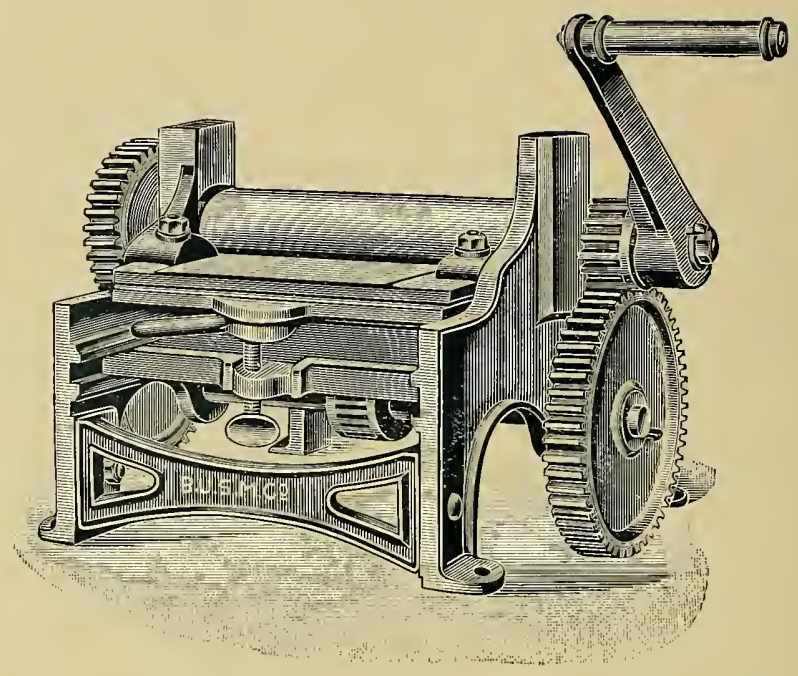

\section{Splicing, Scarfing or Bevelling Machine.}

TE machine illustrated above is designed for splicing, scarfing or bevelling a perfect bevel. The splices are quickly cut, and the machine is adjustable to different lengths of splices.

They are used in the belt making industry, and in factories, mills, workshops, etc., using leather, belting. They are made in four sizes.

Approx. weight.
Size of Machine. $\quad$ Price. cwts. qret. lbs. cwts. Grs. lbs. $\begin{array}{lllllllllll}\text { Width of knife, } 7 " \text { single geared } \ldots & \text { \&6 } & \mathbf{0} & \mathbf{0} & 0 & 3 & 0 & 0 & 3 & 22\end{array}$

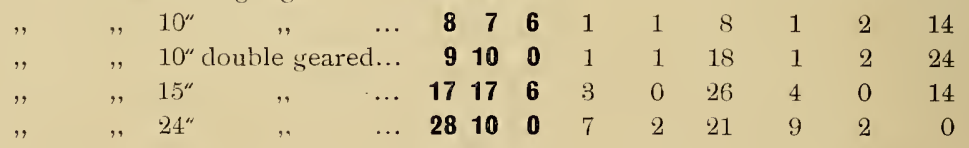

SPARE KNIVES.

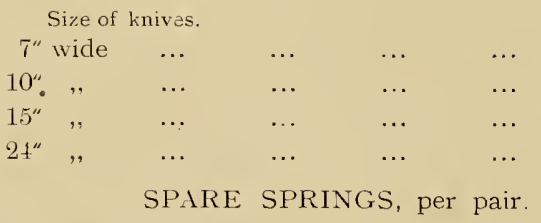

Size of machine.

$7 "$ wide

$\ldots$

$10^{\prime \prime},, \quad \ldots$

$15^{\prime \prime},, \quad \ldots$

$24^{\prime \prime}, \quad \ldots$

$\cdots$
$\cdots$
$\cdots$

$\begin{array}{ll}\cdots & \cdots \\ \cdots & \cdots \\ \cdots & \cdots \\ \cdots & \cdots\end{array}$

$\begin{array}{cc} & \text { Price. } \\ \ldots & \mathbf{3} / \\ \ldots & \mathbf{4} / \mathbf{3} \\ \ldots & \mathbf{6} /- \\ \ldots & \mathbf{1 2} /-\end{array}$




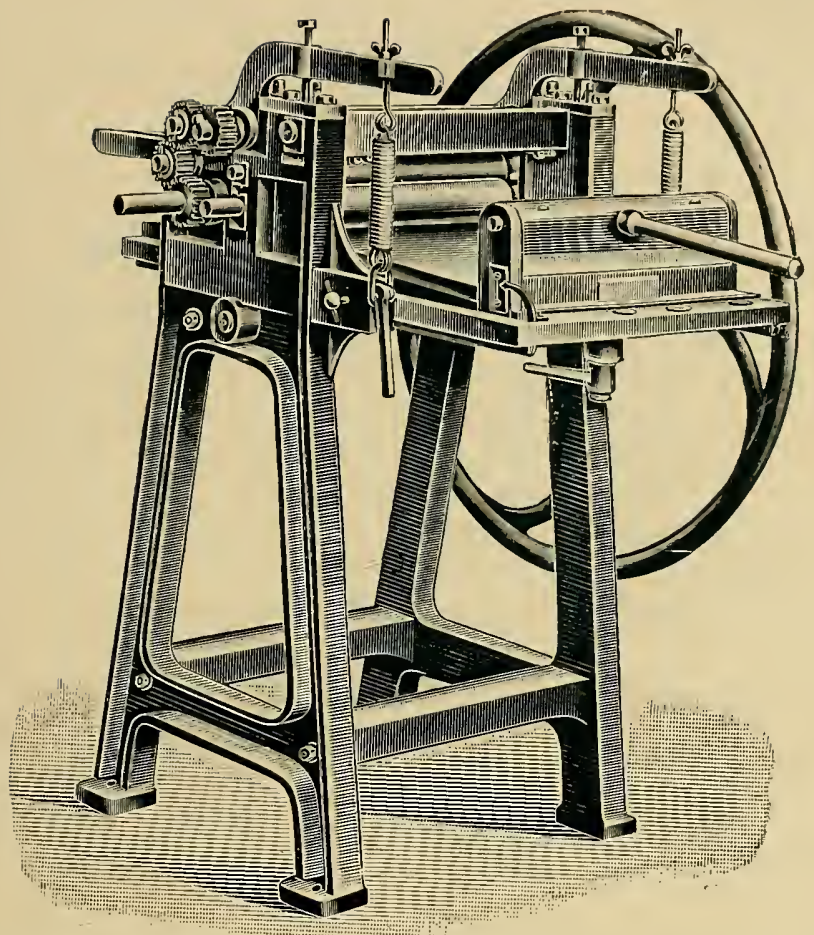

\section{Belt Splicing \& Leather Splitting Machines.}

HE illustration represents a Combined Splicing and Splitting Machine with which perfect results may be obtained. Any length of splice may be cut, finished with either a feather edge or any thickness of edge that may be required, without risk of tearing the leather.

A most useful feature is the arrangement of the knife, which may be sharfened without removing it from the machine.

The necessary adjustments for changing the machine from a splicer to a splitter, or vice versa, are effected in a few minutes, and the machine is capable of equally good work for either purpose.

The machines are also made for splicing only, and for splitting only.

\begin{tabular}{|c|c|c|c|c|c|c|c|c|c|}
\hline \multirow{3}{*}{$\begin{array}{l}4^{\prime \prime} \\
8^{\prime \prime}\end{array}$} & \multirow[b]{2}{*}{$\ldots$} & \multicolumn{3}{|c|}{$\begin{array}{l}\text { Splicing } \\
\text { Machines. }\end{array}$} & \multicolumn{3}{|c|}{$\begin{array}{l}\text { Splitting } \\
\text { Machines. }\end{array}$} & \multicolumn{2}{|c|}{$\begin{array}{l}\text { Combined } \\
\text { Machines. }\end{array}$} \\
\hline & & $£ 17$ & 10 & 0 & $£ 12$ & 10 & 0 & $£ 181$ & 100 \\
\hline & $\ldots$ & 22 & 10 & 0 & 17 & 10 & 0 & 231 & 100 \\
\hline $12^{\prime \prime}$ & $\ldots$ & 27 & 10 & 0 & 22 & 10 & 0 & 281 & 100 \\
\hline $16^{\prime \prime}$ & $\ldots$ & 35 & 0 & 0 & 27 & 10 & 0 & 371 & 100 \\
\hline $24^{\prime \prime}$ & $\ldots$ & 45 & 0 & 0 & 32 & 10 & 0 & 471 & 100 \\
\hline $32^{\prime \prime}$ & $\ldots$ & 60 & 0 & 0 & 50 & 0 & 0 & 621 & 100 \\
\hline $40^{\prime \prime}$ & $\ldots$ & 70 & 0 & 0 & 60 & 0 & 0 & 75 & $\begin{array}{ll}0 & 0\end{array}$ \\
\hline $60^{\prime \prime}$ & $\ldots$ & 130 & 0 & 0 & & $\ldots$ & & 135 & 0 \\
\hline
\end{tabular}

The prices are for hand-power machines. Splitting machines from $16^{\prime \prime}$ and upwards are also made for belt-power at an extra charge of $\$ 5$ each for the $16^{\prime \prime}$ and $24^{\prime \prime}$ machines. 


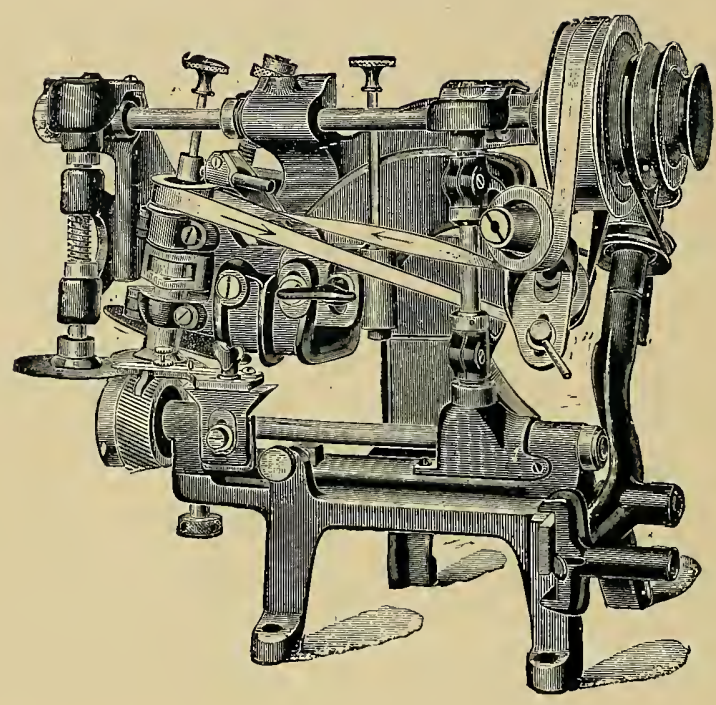

\section{No. 7 Friction Feed Amazeen Skiving Machine.}

HE knife spindle is driven by a belt and includes a friction device which
allows of the knife running at full speed on straight work, and permits of the speed being retarded when skiving curved edges and corners, etc. It is : particularly useful for shiving the tops and bottoms of blocked leggings, and anyother work when a fine skived edge is required.
Price, with power transmitter
$\cdots$
$£ 28100$

Receiving pulley, $11_{5}^{5 n} \times 2 \frac{5}{5}$, runs at 1500 revolutions per mtnute.

$\begin{array}{ccccc}\text { Belt. } & \text { Net weisht. } & \text { Gross weight. } & \text { Bench space. } & \text { Height.. } \\ \frac{5}{16}{ }^{\circ} \text { round. } & 50 \mathrm{lbs} . & 70 \mathrm{lbs} . & 17^{\prime \prime} \times 11^{\prime \prime} & 16^{\prime \prime}\end{array}$




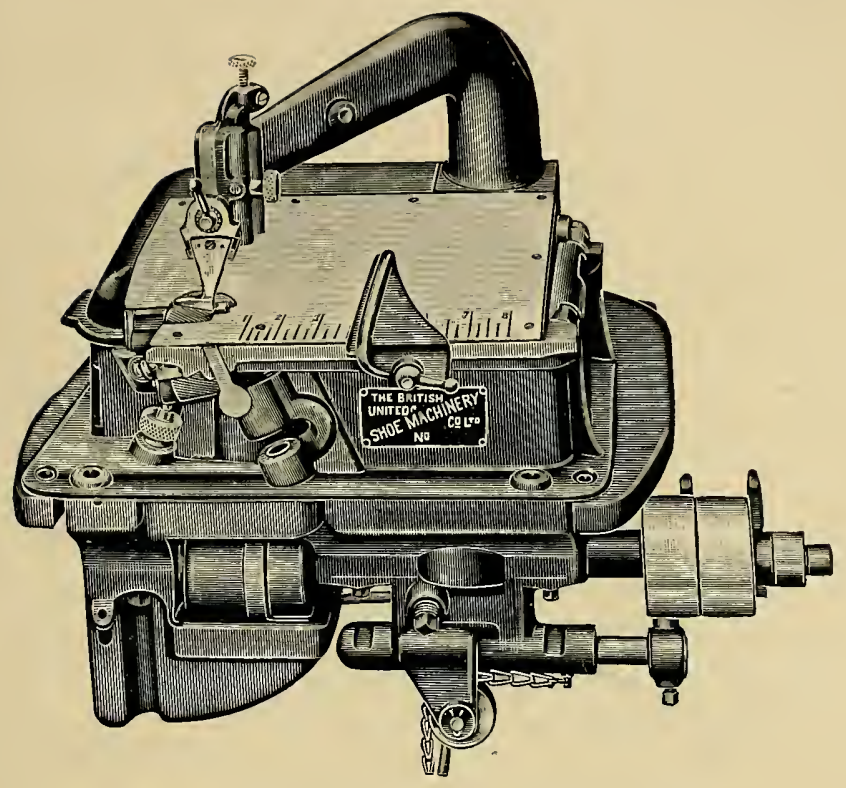

Over-arm Marvel Skiving Machine.

$\mathrm{P}$

RACTICALLY the whole of the working parts of this machine are enclosed within a substantial cast iron casing which effectually protects them from external injury. Only a small portion of the knife is exposed at the point where the skiving is done, so that there is no risk of injury to the operator from this source.

The machine will skive edges, and the scarf may be varied from $\frac{1}{8}$ " to $1^{\prime \prime}$ wide, or a groove may be cut down the middle of a piece of leather up to $16^{\prime \prime}$ wide, the width and depth of the groove being varied as required. Two grinding stones are included in the machine which act on both sides of the knife, thus ensuring a perfectly true and keen edge.

The machine is capable of skiving all kinds of leather used in the fancy leather trades, including the finest and softest, and is used for levelling leather to an eren thickness.

$$
\text { Price } \quad \ldots \quad \ldots \quad \$ 32 \quad 0 \quad 0
$$

Receiving pulley, $3^{\prime \prime} \times 2^{u}$, runs at 1,200 revolutions per minute.

\begin{tabular}{|c|c|c|c|c|}
\hline Belt. & $\begin{array}{l}\text { Net weight. } \\
110 \mathrm{lbs} .\end{array}$ & $\begin{array}{l}\text { Gross weight. } \\
140 \text { lbs. }\end{array}$ & $\begin{array}{l}\text { Bench space. } \\
20^{\prime \prime} \times 14^{\prime \prime}\end{array}$ & $\begin{array}{l}\text { Height above bench. } \\
\qquad 12^{\prime \prime}\end{array}$ \\
\hline
\end{tabular}




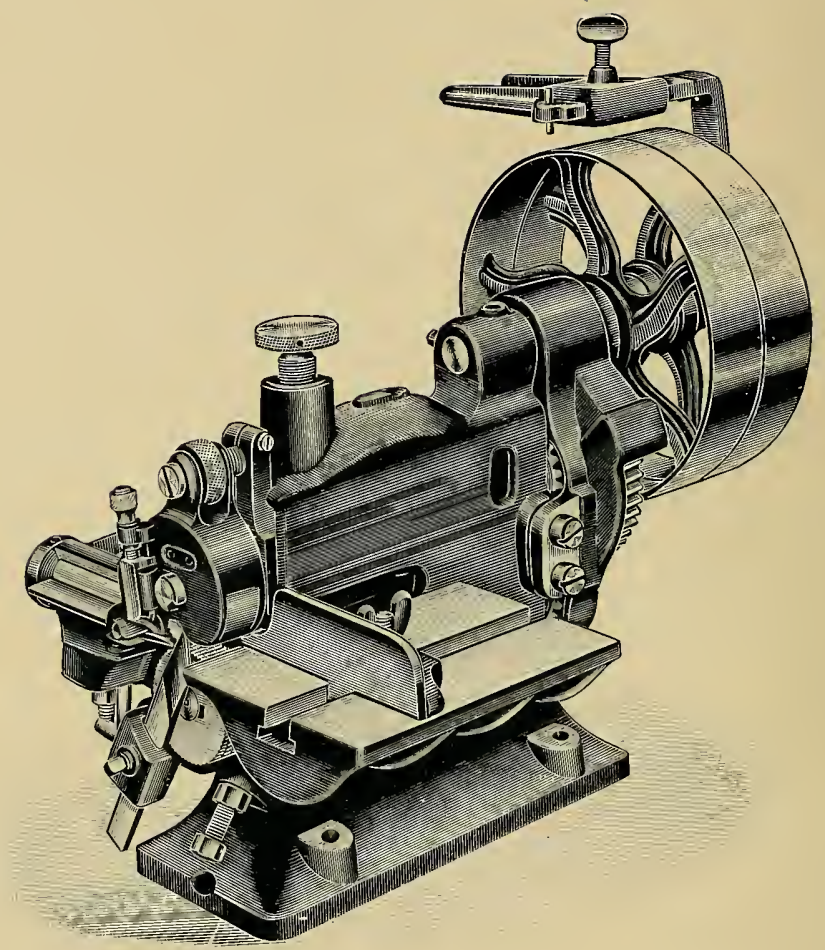

\section{Universal Skiving Machine.}

SUITABLE for ranging strips of leather for belting, also for bevelling the: edges of stout leather.

$$
\text { Price } \quad \ldots \quad £ 710 \quad 0
$$

Receiving pulley, $9^{\prime \prime} \times 2^{\prime \prime}$, runs at 130 revolutions per minute.

$\begin{array}{ccccc}\text { Belt. } & \text { Net Weight. } & \text { Gross weight. } & \text { Bench space. } & \text { Height. } \\ 17 \frac{1}{2}^{\prime \prime} & 7 \mathrm{lbs} . & 125 \mathrm{lbs} . & 28^{\prime \prime} \times 16^{\prime \prime} & 17^{\prime \prime}\end{array}$




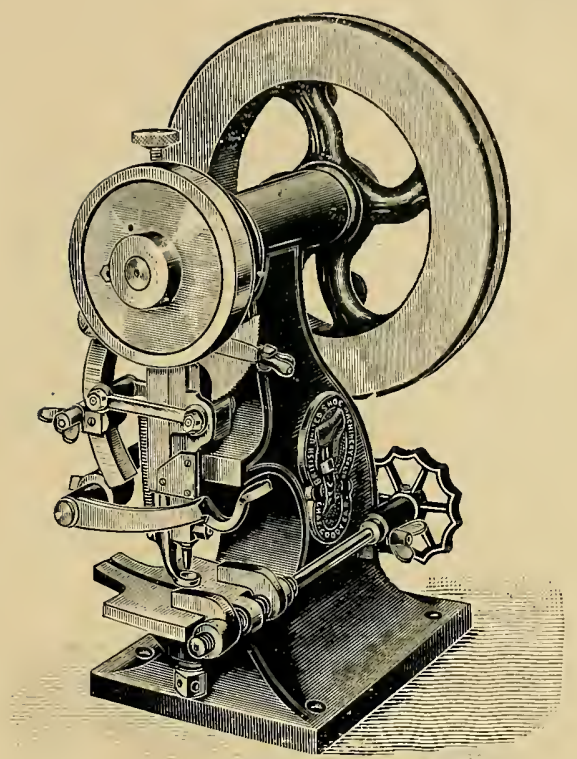

\section{Strap Punching Machine.}

$\mathrm{T}^{\mathrm{n}}$

$\mathrm{EE}$ illustration represents a machine for punching holes in straps, etc., which is in general use by leather goods manufacturers. The machine is operated by t hand-wheel, and can also be used by power; round punches from 1 to 10 , and oval punches from 19 to 25 are used. The distance between the holes can be regulated as required from $3{ }^{3 \prime}$ to $2^{\prime \prime}$ apart. Twin guides are provided which are simultaneously adjusted to equal distances on either side of the punch, so that the holes are always punched along the middle of the straps.

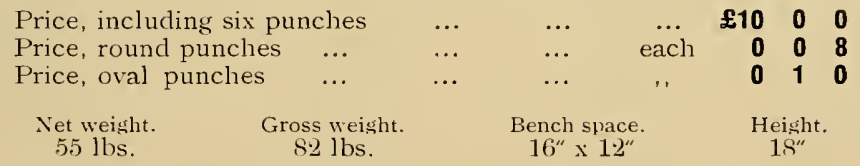

\section{Hose Pipe Punching Machine.}

FOR punching holes along the edges of hose pipe leathers, a special table is. provided. With soft material, the leather may be folded and both edges are punched together, thus ensuring perfect register. The distance between the holes, from the edge of the leather, being varied as required. Made for fixing to a bench.

Price, to work by hand $\ldots$ Price, to work by power

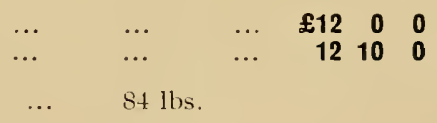




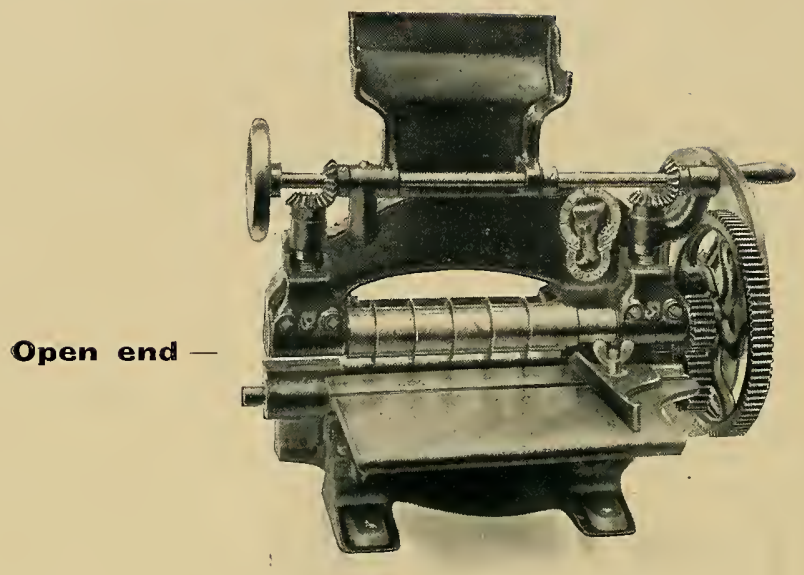

\section{Strap Cutting Machine.}

$F^{\circ}$

OR cutting large quantities of straps this machine is a great time-saver. It is open at one end so that straps may be cut from a whole hide, and there is absolutely no was:e between each sirap cut. Makers of leather straps of any description, and of belt laces, will find it a great acquisition. Cloth, plush, etc., may also be cut into strips for hinding edges, etc.

By straightening one edge of the hide, the machine will cut at one operation as many strips as the machine has cutters.

The heavy hand-wheel is grooved so that the machine may be operated either by hand or power.

The greatest width the machines will cut is $S^{\prime \prime}$, but they are more generally used for cutting straps and laces as per widths given below and intermediate sizes.

A great improvement has been added to this machine, which enable the rolls and cutters to be c.ranged as required in a few minutes.

\begin{tabular}{|c|c|c|c|c|c|}
\hline \multirow{3}{*}{$\begin{array}{l}\text { Width of } \\
\text { Strap. } \\
2^{\prime \prime}\end{array}$} & \multirow{2}{*}{\multicolumn{3}{|c|}{$\begin{array}{l}\text { No. of } \\
\text { Cutter. }\end{array}$}} & \multicolumn{2}{|c|}{$\begin{array}{l}\text { Nachine complete } \\
\text { with one set }\end{array}$} \\
\hline & & & & $\begin{array}{l}\text { of Cutte } \\
£ 11 \quad 10\end{array}$ & o \\
\hline & $\begin{array}{l}\cdots \\
\cdots\end{array}$ & 5 & $\begin{array}{l}\cdots \\
\ldots\end{array}$ & 1115 & 0 \\
\hline $1 \frac{1}{2} "$ & $\ldots$ & 6 & $\ldots$ & 120 & 0 \\
\hline $1 \frac{1}{!}$ & $\ldots$ & 7 & $\ldots$ & 125 & 0 \\
\hline $1^{\prime \prime}$ & $\ldots$ & 8 & $\ldots$ & 1210 & 0 \\
\hline$\frac{7}{8} "$ & $\ldots$ & 9 & $\ldots$ & 1215 & 0 \\
\hline 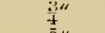 & $\ldots$ & 11 & $\ldots$ & 135 & 0 \\
\hline 咅“ & $\ldots$ & 13 & $\ldots$ & 1315 & 0 \\
\hline$\frac{1}{2} "$ & $\ldots$ & 15 & $\ldots$ & 142 & 6 \\
\hline$\frac{5}{8}$ & $\ldots$ & 18 & $\ldots$ & 1415 & 0 \\
\hline$\frac{1}{4} "$ & $\ldots$ & 28 & $\ldots$ & 165 & 0 \\
\hline$\frac{3}{16} 4$ & $\ldots$ & 40 & $\ldots$ & 180 & 0 \\
\hline
\end{tabular}

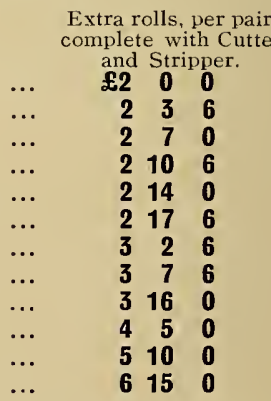

When ordering, please send sample strap shewing exact width it is required to cut. Receiving pulley, $12_{2}^{14}$ grooved, runs at 90 revolutions per minute.

$\begin{array}{ccccc}\text { Round belt. } & \text { Net weight. } & \text { Gross weight. } & \text { Bench space. } & \text { Height. } \\ \xi^{\prime \prime} & 145 \text { lbs. } & 206 \text { lbs. } & 26^{\prime \prime} \times 22^{\prime \prime} & 141_{2}^{\prime \prime}\end{array}$




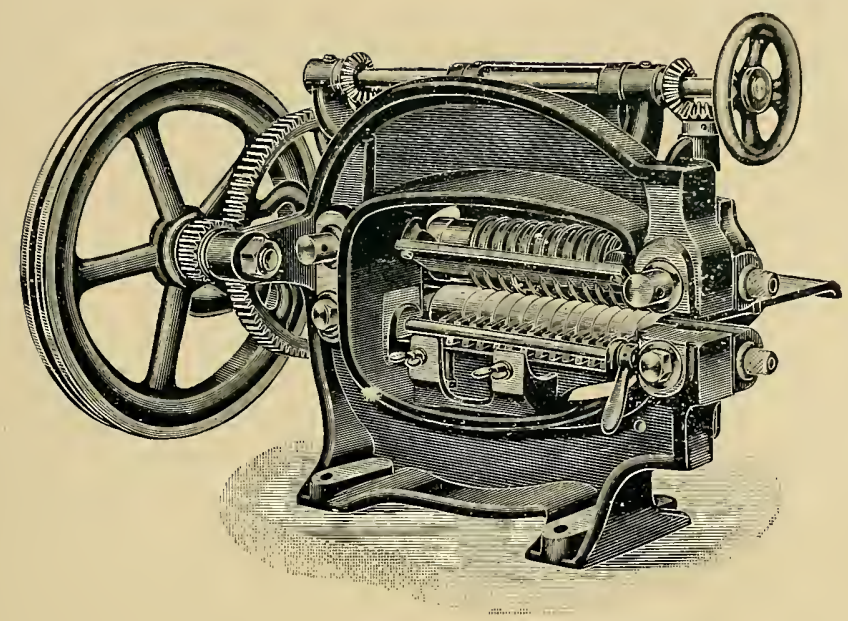

\section{Strap Cutting Machine.}

\section{$\mathrm{T}$}

$\mathrm{HE}$ grooves in the lower roll are liable to receive dust and small particles of leather which is compressed by the cutters, and in course of time the grooves ecome filled with hard compressed dust, etc., which takes off the keen edges of the cutters and sometimes causes them to chip.

To overcome this difficulty we provide "groove cleaning fingers," which are shown in the above illustration. Each finger has a thin blade fixed in it, which enters a groove and scrapes out any dirt that gets into it, and so prevents the groove becorming filled up. The fingers are adjustable to any width, and may be used with any number of change rolls. 


\section{Sewing Machines.}

$\mathrm{W}^{\mathrm{r}}$

ITH the exception of the No. 4 Leather Belt Sewing Machine, all our Sewing Machines are supplied either on stands, as illustrated, or without stands, so that they may be fixed on a bench and run by power, in which case a Power Transmitter is required. The Special Power Transmitter is a simple piece of mechanism by means of which the working of a machine is controlled, the starting of a machine being effected by simply pressing the footplate, while releasing the pressure causes the machine to stop instantly.

The No. 4 Belt Sewing Machine is fixed on a stand on which it is worked by power or by treadle.

The following machines are also made to be run by power on their own stands. at an extra cost of 35/- each ; Nos. 1 and 2 Saddlers' Machines, 18" Machines, Nos. 1 and 2 Coachmakers' Machines, the $A 1$ Machines, and also the No. 6 Harness Makers' Machines.

The following price list of Shafting, etc., has been compiled for the convenience of customers who may wish to provide means of running their machinery by power when they are fixed on benches. These parts are always kept in stock.

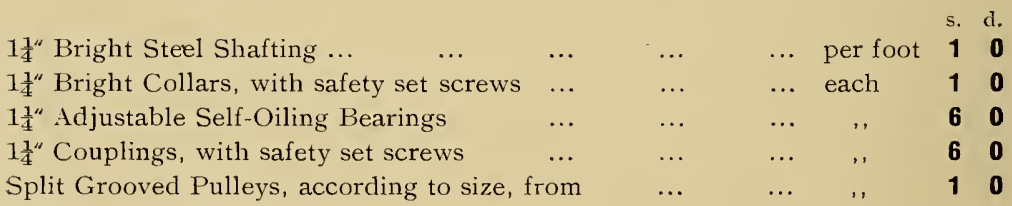

\section{Spare Parts.}

It is always advisable for machines sent abroad, that they be accompanied by an assortment of spare parts, including needles, shuttles, springs, screws, etc., and we are prepared to make up what we consider to be the most useful assortment for from £1 $10 \quad 0$ to £2.

See pages 44 to 47 . 


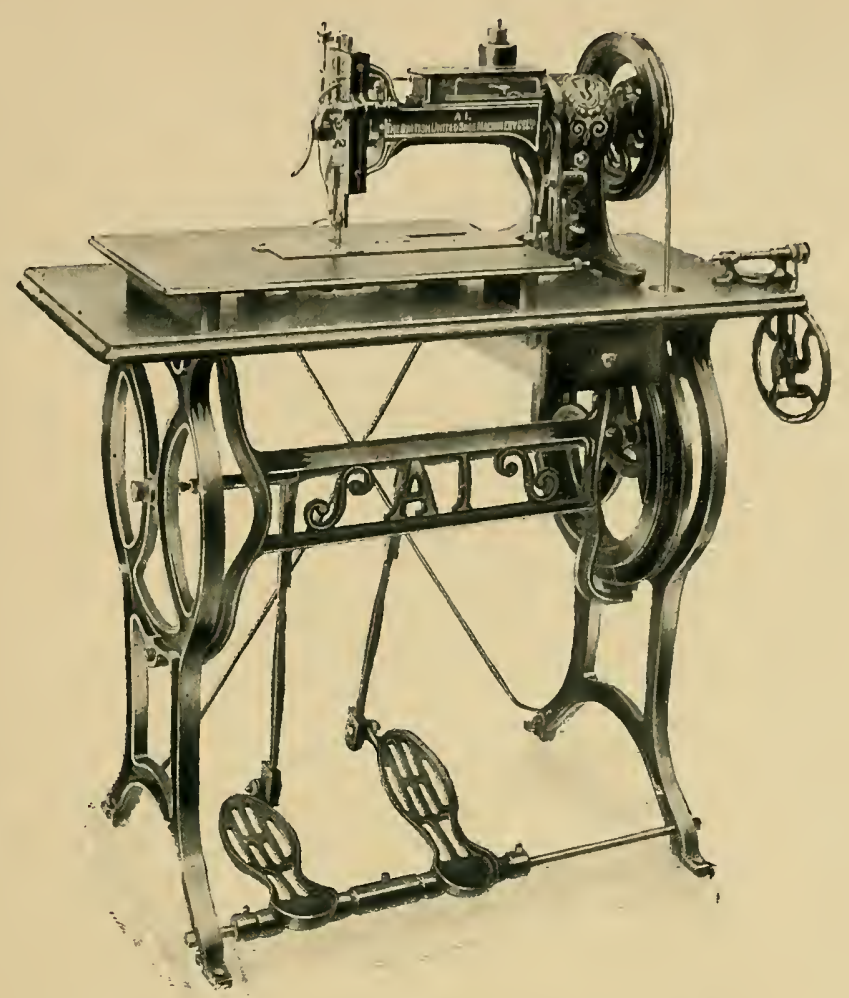

\section{A1 Wax-Thread Sewing Machine.}

$\mathrm{M}$

ANUFACTURERS of horse clothing, leggings, footballs, riding saddles, and general harness work, carriage trimming, etc., in all parts of the \& world are using this machine.

Special presser feet are supplied with the machines according to the work to be done.

8 a 382 The machines use thread up to 5 cord No. $1 \mathrm{~S}$, and make stitches from 4 to 16 per inch, and sew leather to a thickness of $\frac{5 . "}{113}$.

8 . 382 The A1 Special Machine, for light saddlery and harness, has interchangeable pricking feet similar to those on our well-known "No. 6 Machine." For general repair work the machine is indispensable.

The accessories supplied include a special binding gauge which is capable of turning wide binding equal on both sides or wider on the top or bottom, as may be required.

The A1 Ordinary Machine is provided with bottom feeder only, and with a non-vibrating presser foot, it is used on army accoutrements, leggings, and any light leather work.

The Coach and Carriage Builders' Machine is specially made for plain sewing, welting, lace cording, cushion making, etc.

The A1 Ordinary Machine, for accoutrements, leggings, etc., on stand $£ 10100$

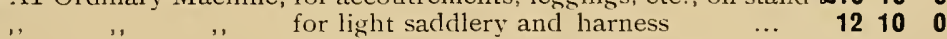

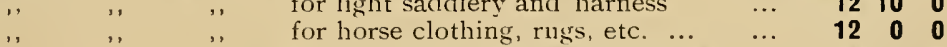

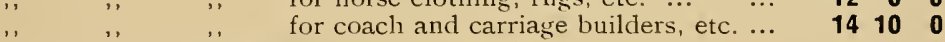

Any of the above supplied withont stand, deduct $\quad \ldots \quad \ldots \quad \ldots \quad 1100$

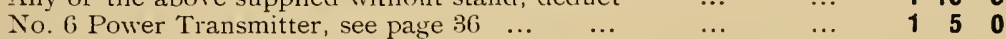

Double-grooved receiving pulley, $6 "$ and $t^{\prime \prime}$, runs at $5(x)$ to $6(0)$ revolutions ner mint te.

Net weight. Gross weight. Heor space.

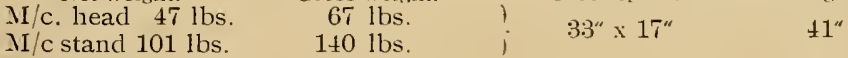




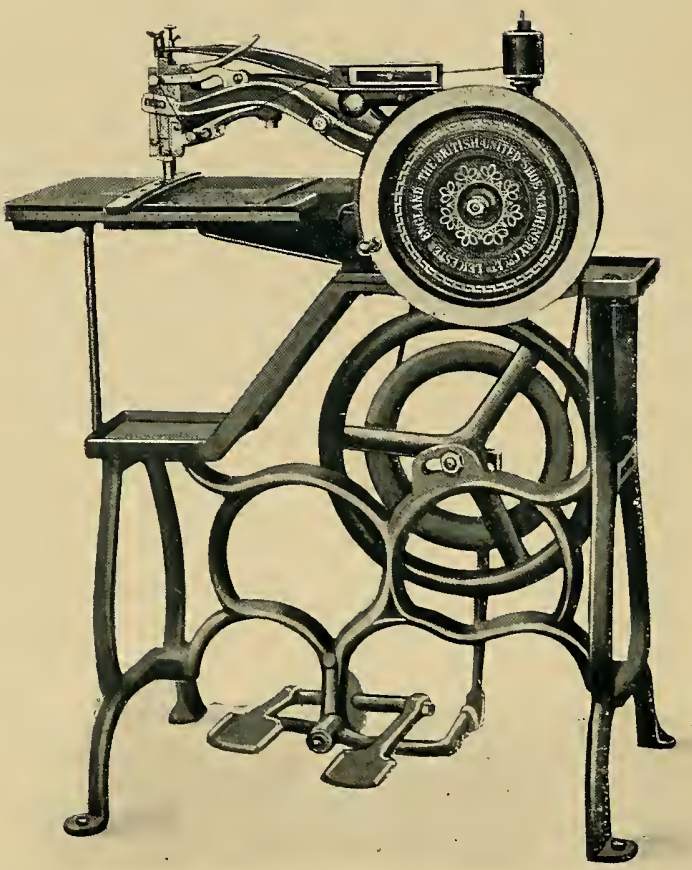

\section{No. 1 Wax Thread Sewing Machine.}

\section{For Coach and Carriage Builders.}

THIS machine is fixed on a special stand for sewing the outside and inside rows of wings and dashes (it will not sew centre bars). Brougham seat borders can be welted in 30 to 35 minutes; an apron in 50 to 60 minutes; a head valance in 30 to 45 minutes; a pair of brougham dcor wings can be sewn in 30 to 40 minutes; a brougham clash can be sewn (with exception of the middle bar) in 30 to 45 minutes.

A wax pot is included for waxing thread with cold wax solution, or the thread may be used dry, as required.

Price of machine on special stand for treadle, and complete with all necessary appliances to suit above-mentioned work ...

Note. This machine is also provided with the necessary appliances

to do the work of the $A 1$ machine (see page 37 ).

Arranged to work by both foot and power, extra

Without stand, to fix on a bench, deduct

No. 6 Power Transmitter (see page 36 ) ...

$\begin{array}{llllrl} & \cdots & \cdots & 1 & 15 & 0 \\ \cdots & \cdots & \cdots & 2 & 0 & 0 \\ \cdots & \cdots & \cdots & 1 & 5 & 0\end{array}$

Receiving pulley, $6^{\prime \prime}$ and $8^{\prime \prime}$ diameter, runs at 300 to 400 revolutions per minute.

$\begin{array}{lcccc}\text { Belt. } & \text { Net weight. } & \text { Gross weight. } & \text { Flocr space. } & \text { Height. } \\ & \text { Head } 97 \text { lbs. } & 217 \text { lbs. } & 32^{\prime \prime} \times 19^{\prime \prime} & 44^{\prime \prime}\end{array}$




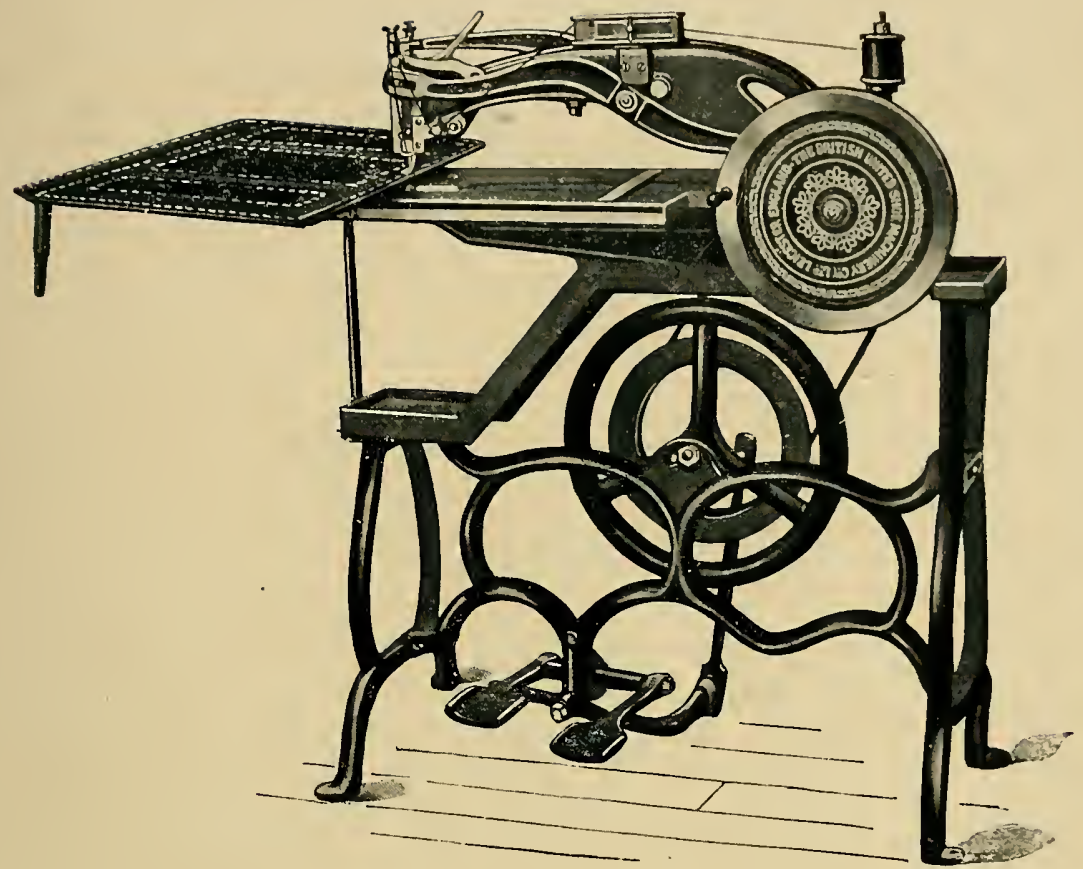

\section{No. 2 Wax Thread Sewing Machine.}

\section{For Coach and Carriage Builders.}

$T^{\text {H }}$

HIS machine is the same in general principle to No. 1 , but is made stronger and has a clear space of $18^{\prime \prime}$ under the arm, thus enabling centre bars of dashes and wings to be sewn up to that distance from the edge. Will also sew welting.

A wax pot is provided for waxing the thread with cold solution wax, or the thread may be used dry, as required.

Price of machine on special stand for treadle Arranged for both power and treadle, extra Vithout stand, to fix on bench, deduct

$$
\begin{array}{lllllll}
\text { Price of machine on special stand for treadle } & \ldots & \ldots & \ldots & \ldots 21 & \mathbf{1 0} & \mathbf{0} \\
\text { Arranged for both power and treadle, extra } & \ldots & \ldots & \ldots & \mathbf{1} & \mathbf{1 5} & \mathbf{0} \\
\text { Vithout stand, to fix on bench, deduct } & \ldots & \ldots & \ldots & \mathbf{2} & \mathbf{0} & \mathbf{0} \\
\text { No. } 6 \text { Power Transmitter, to suit any bench (see page } & 36) & & \ldots & \mathbf{1} & \mathbf{5} & \mathbf{0}
\end{array}
$$

Rereiving pulley, $6^{\prime \prime}$ and $8^{\prime \prime}$ diameter, runs at 300 to 400 revolutions per minute.

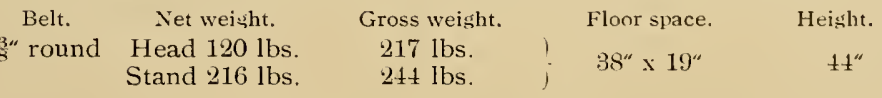




\section{Nos. 1 and 2 Saddlers' and Harness Makers' Sewing Machines.}

$\prod \begin{gathered}\mathrm{HE} \text { ordinary No. } 1 \text { Machine was the first machine invented for using waxed } \\ \text { threads, and a large number of them have been sold for sewing saddlery }\end{gathered}$ and harness, bags, footballs, dashes, wings, canvas belts, etc.

All these machines are very strongly made, and are of simple construction. so that anyone unaccustomed to sewing machines may soon learn to work them satisfactorily. Many of them are being worked by women and girls.

The No. 1 Ordinary Machine is provided with a bottom feeder only, and a vibrating presser-foot. It is a good machine for sewing plain work, such as. winkers, flat and rounded straps, light traces up to $\frac{3}{8}$ ths of an inch thick, etc., Special pricking-up feet, such as are used with the Nos. 1 and 2 Saddlers' and Harness Makers' Machines cannot be used on this machine.

The No. 1 Saddlers' and Harness Makers' Machine is provided with both top and bottom feeders working in unison, by which arrangement two or more thicknesses may be sewn together without risk of them sliding or moving out of position in relation to eacl other.

Special pricking-up feet are supplied with this machine, by means of which each stitch is pricked up or moulded as it is made, and the sewing produced has. a very handsome appearance.

This machine will do all the work that can be done by the No. 1 "Original ". Machine, and will sew traces up to nearly half-an-inch in thickness.

The No. 2 Saddlers' and Harness Maker's Machine is very similar to the No. 1 Machine, but it has a heavier cam wheel and the needle has a longer stroke. It is not quite so suitable for light work as the No. 1 , but is better for heavier work.

The speed of the above machines is about 400 stitches per minute, and the sizes of thread vary from 3 to 8 cord No. 18 .

Either of the above machines may be provided with our Hard-Wax Apparatus.

A similar machine to these provided with both top and bottom feeders is. made with an $18^{\prime \prime}$ arm, for sewing splash boards, trunks, dress baskets, etc. 


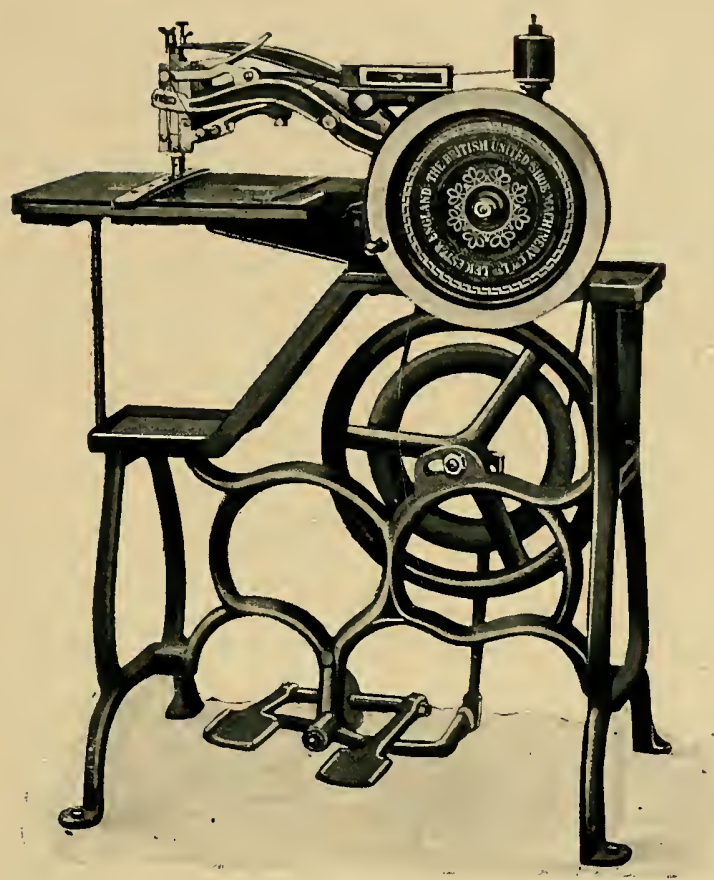

\section{Nos. 1 and 2 Saddlers' and Harness Makers' Sewing Machines.}

No. 1 Ordinary IVax-Thread Nachine

$$
\ldots \quad \ldots \quad \ldots £ 1210 \quad 0
$$

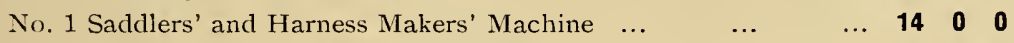

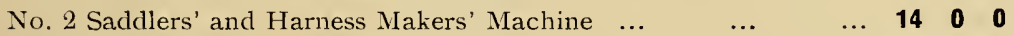

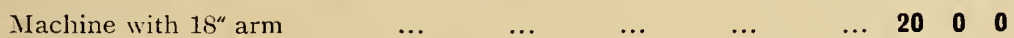

$$
\begin{array}{lllrrr}
\text { If supplied without stand, less } & \ldots & \ldots & \text { 1 } & \mathbf{1 5} & \mathbf{0} \\
\text { No. } 6 \text { Power Transmitter, see page } 36 & \ldots & \mathbf{1} & \mathbf{5} & \mathbf{0}
\end{array}
$$

Either of the above machines can be fitted with our Patent Bottom Hard Waxing Apparatus at an extra charge of $\mathbf{\& 4}$.

If the Hard IVax Apparatus is required, state particularly whether it is to be heated by gas or lamp.

Double-grooved receiving pulley, $6 "$ and $s^{\prime \prime}$, runs at 300 to 400 revolutions per minute.

Net Weisht.

$\mathrm{N} / \mathrm{c}$ head $98 \mathrm{lbs}$.

$\mathrm{M} / \mathrm{c}$ stand $216 \mathrm{lbs}$.
Gross Weight.

217 lbs.

$24+$ lbs.
Floor space.

$322^{\prime \prime} \times 19^{\prime \prime}$

Height. 


\section{No. 2 Trunk and Bag Makers' Sewing Machine.}

\section{For illustration see pages 39 and 41 .}

HIS machine is similar to the No. 2 Saddlers' Machine, and is used for
general trunk work, etc. Overland trunk, Gladstone and brief bay handles are very successfully sewn, as also are welting, binding, and piping. The machines are made to use a broad-pointed needle, which makes a long. slanting stitch-the stitch that trunk makers prefer.

Price of Machines on Stand for treadle:-

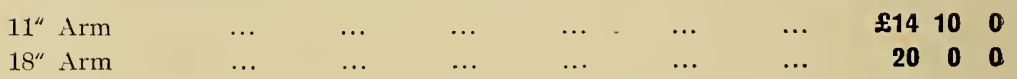

Double-grooved receiving pulley, $8^{\prime \prime}$ and $6^{\prime \prime}$, runs at 300 to 400 revolutions per minute.

\begin{tabular}{|c|c|c|c|c|c|}
\hline Belt. & Net weight. & Gross weight. & & Floor. & Height. \\
\hline$\frac{3}{8} \times$ round. & $11^{\prime \prime} \mathrm{M} / \mathrm{c}$ head $95 \mathrm{lbs}$. & 144 lbs. & $\vdots$ & $32^{\prime \prime} \times 19^{\prime \prime}$ & $44^{\prime \prime}$ \\
\hline round. & $\begin{array}{l}18^{\prime \prime} \mathrm{M} / \mathrm{c} \text { head } 161 \mathrm{lbs} . \\
18^{\prime \prime} \mathrm{M} / \mathrm{c} \text { stand } 158 \mathrm{lbs} .\end{array}$ & $\begin{array}{l}217 \text { lbs. } \\
196 \text { lbs. }\end{array}$ & $i$ & $38^{\prime \prime} \times 12^{\prime \prime}$ & $44^{\prime \prime}$ \\
\hline
\end{tabular}




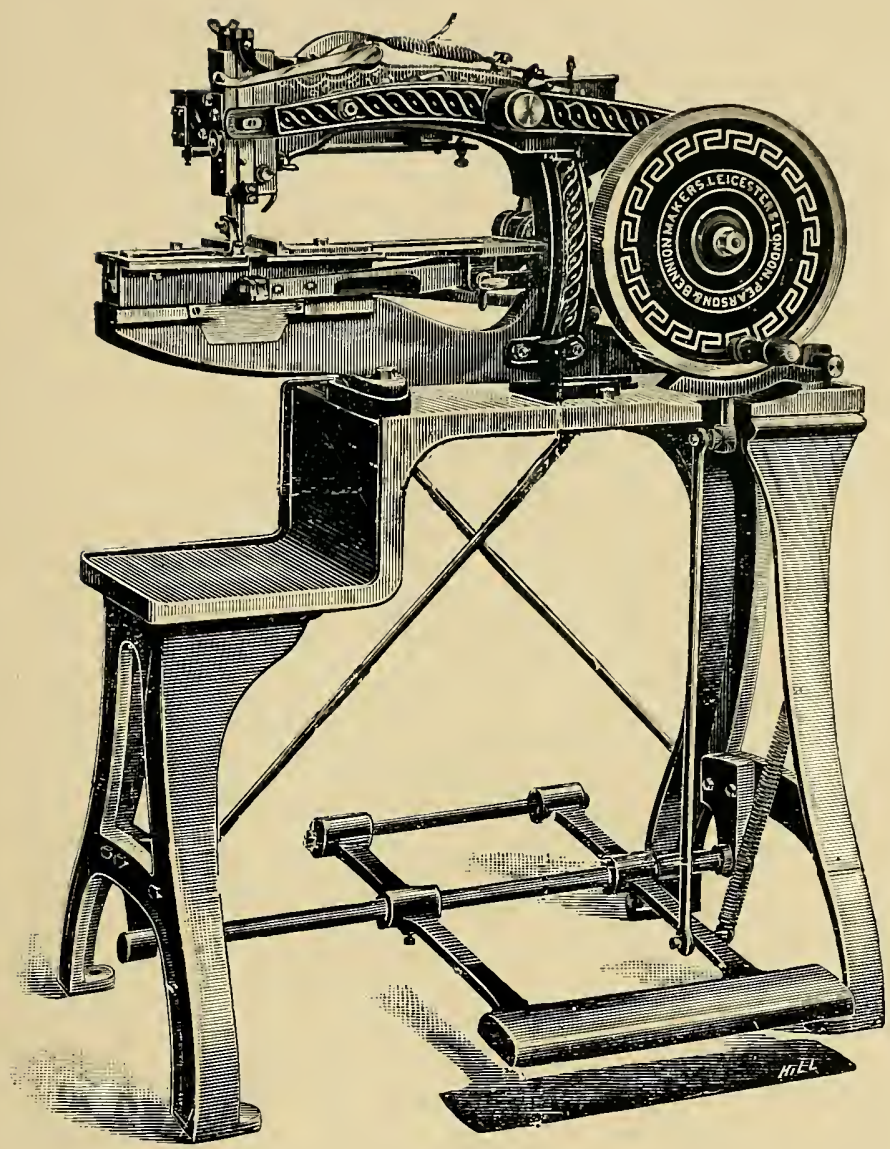

No. 4 Leather Belt Sewing Machine.

Price, complete, as illustrated, with waxer, shuttle reel winder, and

all necessary accessories, for belt power

Price, to work by foot power ...

Receiving pulley, $8{ }_{1}^{10}$, runs at 200 revolutions per minute.

Machine head

Nachine stand
Gross weisht. 487 lbs. 460 lbs.
Floor space.

$49^{\prime \prime} \times 32^{\prime \prime}$
Height.

$59 "$

All necessary accessories inclucled.

Notc. When orclering, state whether for gas or oil.

See pages 44 to 47 . 


\section{Nos. 4 and 6 Belt Sewing Machines.}

$\mathrm{T}^{1}$

HE No. 4 Machine, as illustrated on page 43 , is a very strong and powerful machine which will sew from a single thickness of leather up to one inch thick, and is suitable for using thread from 10 cord to 20 cord No. 18. It is provided with a Hard-Wax Apparatus of which two styles are made, one to be heated by gas, while the other is heated by a petroleum or kerosene lamp. Orders should state particularly which method of heating the wax apparatus is required.

The feeding is accomplished by means of an awl, and there is no marking of the leather on either side. The shuttle is very large and the design of the machine is such that the shuttle thread is used to the best advantage. A single reelful is sufficient to sew from 30 to 50 feet of double belting according to the thickness of the belt and the size of thread used.

The accessories supplied with each machine include a separate waxer and winder for shuttle reels so that the reels may be wound independently of the machine.

The length of arm is such that the machine will sew in the MIDDLE OF A BELT 30 inches wide.

Some belt makers prefer the No. 6 Machine, which is made on the needle feed principle. The length of arm is such that the machine will sew in the middle of a belt 24 inches wicle. For light belting the No. 6 Machine is much faster than the No. 4 Machine.

Both machines will sew belts which have been raced or belts which have not been raced. In the latter case, the stitches are pressed into the leather to such an extent that there is no risk of them wearing through. Both machines are made for power driving or to be worked by treadle, as may be required, and they are also made to be worked by both methods, which is sometimes an advantage. These machines are easy to operate, and their adjustments are simple. They cost very little in repairs.

We shall be glad to sew customers' samples on either of these machines or to shew them in operation at our works, by appointment.

These machines are being used by the principle makers of leather belting in Great Britain and abroad.

See pages, $43,45,46$, and 47 . 


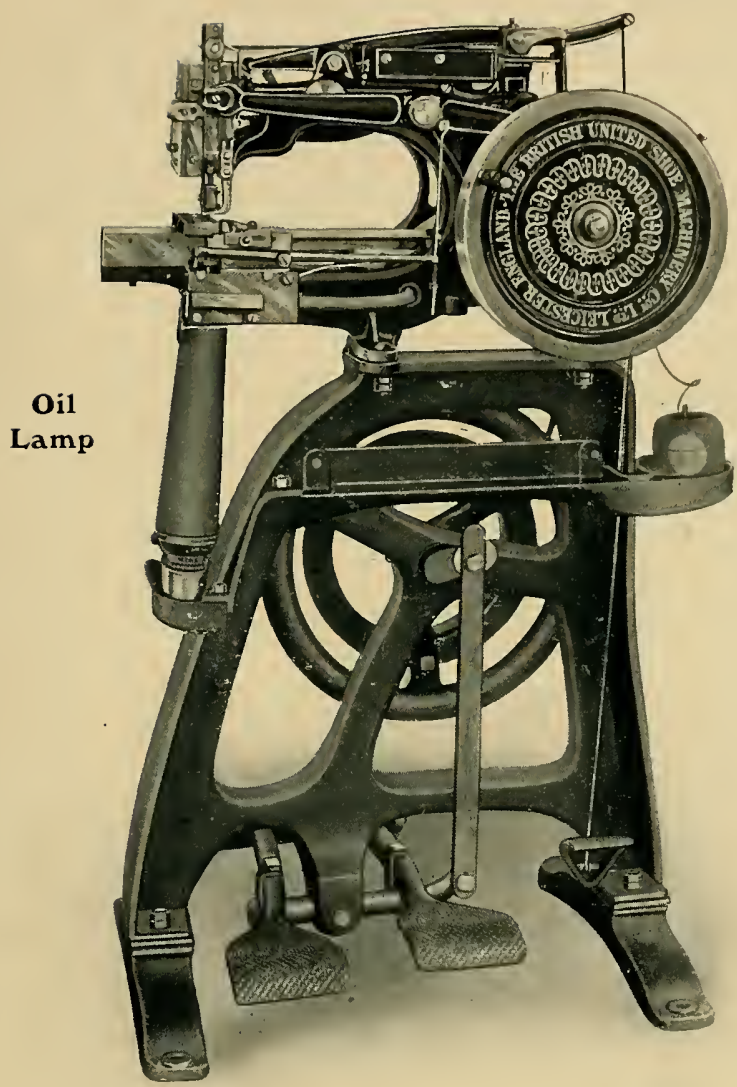

\section{No. 6 Harness Makers' Sewing Machine.}

Price, complete, as illustrated, fitted with bottom (or clipping) waxing apparatus, thread winder, and usual accessories

Price, complete, but fitted with patent top waxing apparatus (see $\begin{array}{llllllll}\text { page } 47) & \ldots & \ldots & \ldots & \ldots & \ldots & \ldots\end{array}$

Price, complete, without hard waxing apparatus, to sew with dry thread or solution

... waxing apparatus, to sew with dry $£ 30 \quad 0 \quad 0$ 3500

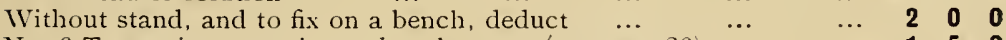
No. 6 Transmitter to suit any bench, extra (see page 36$) \ldots$ Power Transmitter fixed to stand so that the machine may be

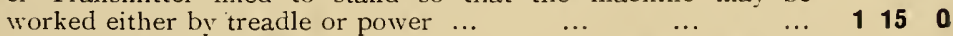
Notc.-When ordering state particularly whether for gas or lamps.

Receiving pulley, $8^{\prime \prime}$ and $6^{\prime \prime}$ diameter, runs at 300 revolutions per minute.

Net weight.

$\mathrm{M} / \mathrm{c}$. head $147 \mathrm{lbs}$.

$\mathrm{M} / \mathrm{c}$. stand $172 \mathrm{lbs}$.
Gross weight.

$203 \mathrm{lbs}$

2.24 lbs
Floor space.

$34^{\prime \prime} \times 18^{\prime \prime}$
Height.

$49^{\prime \prime}$ 


\section{No. 6 Saddlers' and Harness Makers' Sewing Machine.}

HE large number of these machines which we have disposed of bear ex-
cellent testimony as to their stability, and also to the quality of work they are capable of doing.

They are being constantly being despatched to all parts of the world, including every country in Europe, Canada, the United States of America, Australia, New Zealand, South Africa, Egypt, China, Japan, South America, etc.

A Patented Stand makes it easy to treadle, and an Improved Table for supporting the work is provided. This table can be instantly removed if necessary.

The feeding is accomplished by means of the needle, which, after penetrating the work, moves it along the length of a stitch. By this means the undesirable marking caused by corrugated feeders and presser-feet is entirely avoided. Special means are adoped to prevent the needle from springing or breaking while feeding.

The length of stitch may be varied from 4 to 12 to the inch, and the change from one length of stitch to another is instantly effected.

Any thickness of leather, from a single thickness up to three-quarters of an inch, may be sewn without any alteration of tensions.

The shuttle is made as large as possible, and will hold sufficient thread to sew round the longest trace, and the machine is so designed as to use the shuttlethread to the best advantage.

The size of threads the machine will use range from 3 to 10 cord No. 18, and the thread-locking device will lock any thickiness of thread equally well.

The machines, when required, are supplied with a patented Top Waxing Apparatus, by means of which the thread is waxed before it reaches the needle, and so efficiently does it wax the thread that there is no difficulty in meeting the requirements of Government Inspectors of Army work in this respect.

The Waxing Apparatus is generally heated by gas-jets, and a water jacke $\mathrm{t}_{\mathbf{t}}$ which surrounds the wax pot effectually prevents the wax from being burnt. When required, the Waxing Apparatus is made so that it may be heated by a petroleum or kerosene lamp.

Provision is made in each machine for using cold solution wax.

A separate winder, by means of which dry or waxed threads may be wound on to the shuttle reels, is supplied, so that the shuttle reels may be wound independently of the machine.

The speed of the machine, when worked by foot, is as fast as the operator can work it, and, when worked by power, thick traces may be sewn at the rate of 300 stitches per minute, while for light work the speed may be increased to 360 stitches per minute.

A very large proportion of the saddlery and harness work made in Great Britain is being sewn on these machines, and they are also used by the leading saddlery and harness makers, 'bus, tramway, and railway companies throughout the world. 


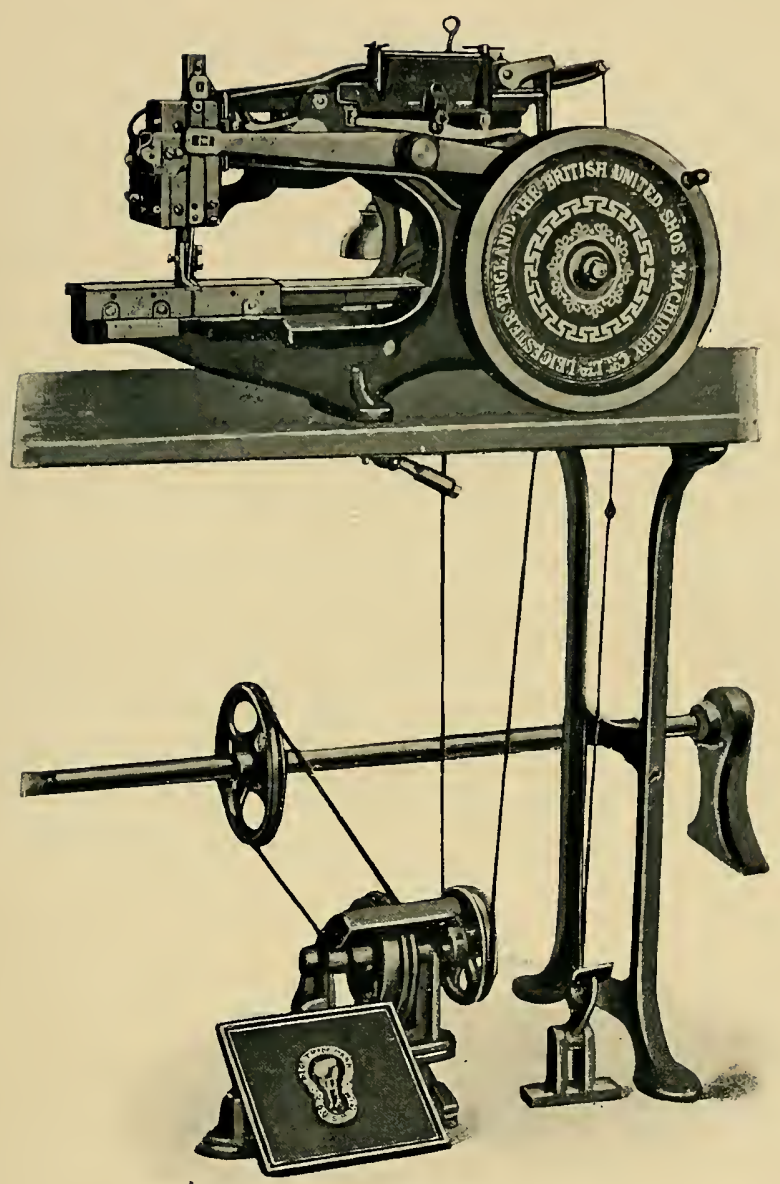

\section{No. 6 Harness Makers' Sewing Machine.}

TE illustration represents the machine fixed on a bench and provided with fixed to the floor.

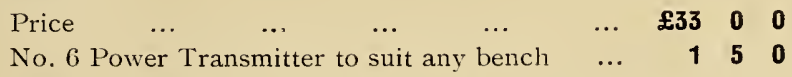

Receivins pulley, $8^{\prime \prime}$ and $6^{\prime \prime}$ diameter. runs at 300 revolutions per minute.
Belt.
Net weight.
Gross weisht.
203 lbs.
Bench space.
$29^{\prime \prime} \times 16^{\prime \prime}$
Height.

Always state whether to be heated by gas or oil.

See pages 44,45 , and 46 . 


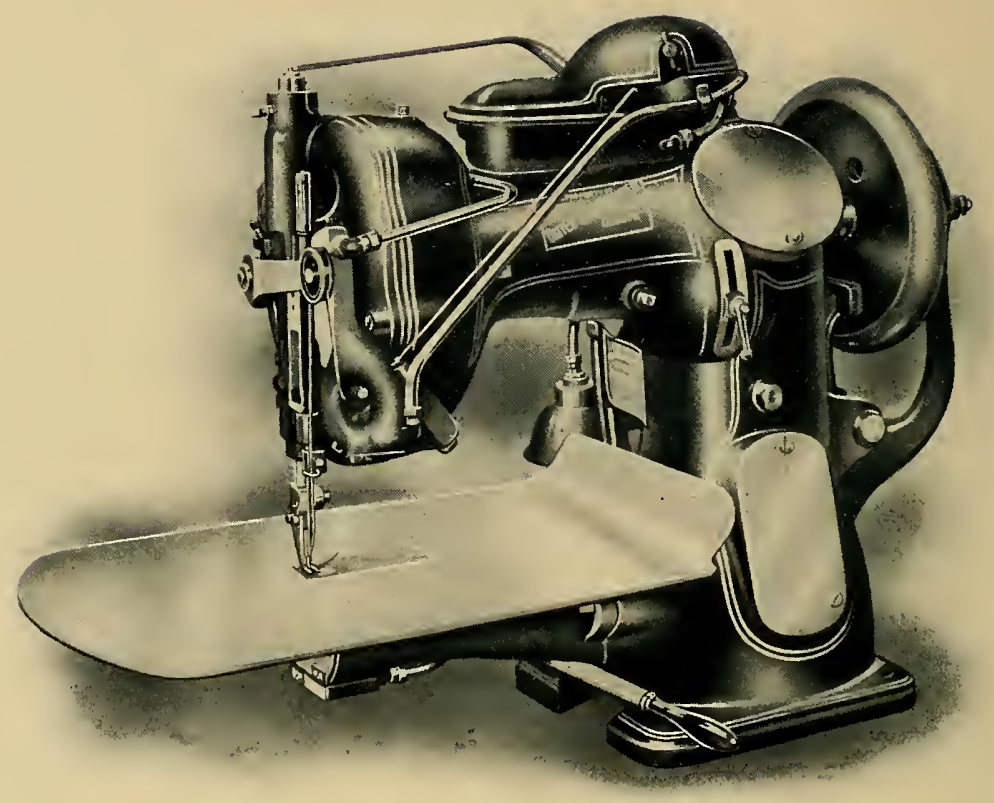

\section{Pilot Sewing Machine.}

$\mathrm{T}^{\mathrm{H}}$

HE Pilot Sewing Machine has been designed for sewing a large range of leather work with a dry thread, or thread waxed with cold liquid wax or melted hard wax. The machine will use thread from 3 Cord No. 30, to 7 Cord No. 18 , and will sew leather from $\frac{1}{16}$ " thick to $\frac{7}{16} "$ thick.

The iron table which is used when sewing flat work may be instantly swung away from the arm when it is desired to use the machine for sewing shaped work.

The arm has a clear length of $10 \frac{1}{2}$ " and a clear height of $6 \frac{1}{2}$ ". The needle works close up to the end of the arm so that sewing may be done in corners which it is imposible to reach with ordinary sewing machines. The machines are being used for sewing saddlery and harness; trunks, bags, and portmanteaux; for closing army and football boots, and for sewing footballs, etc. The machine is also provided with a heating apparatus for melting hard wax for waxing the thread, and with a transmitter for power driving. 


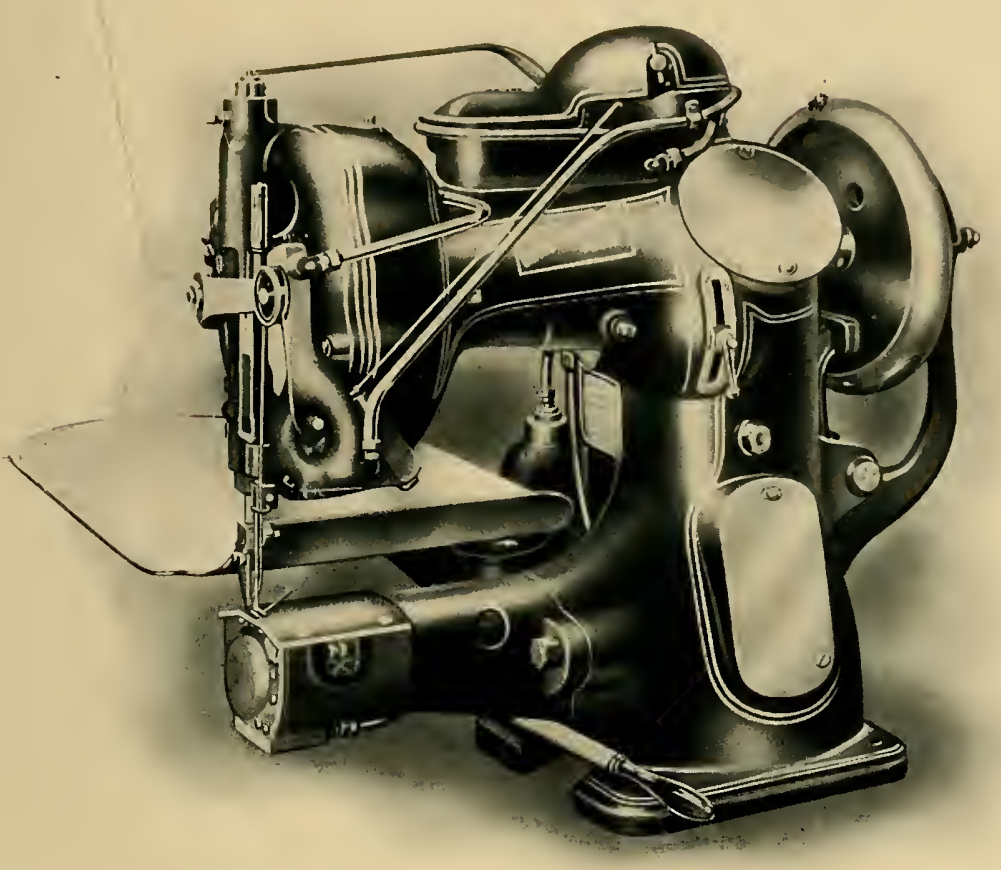

\section{Pilot Sewing Machine.}

Our claims for this machine include:-

Perfect Waxing of the Thread. Automatic Needle Feed,

PERfect Lockstitch.

Automatic Tension.

PERFEct Heating APPARATUS.

Aitomatic Thread Measuring.

Machine complete for fixing to a bench-for using dry thread, solution
wax and hard wax
...
...
...
$\ldots £ 30 \quad 0 \quad 0$

Machine complete for fixing to a bench-for using dry thread only... $27 \quad \mathbf{0} \quad \mathbf{0}$

Iachine complete on stand-for using dry thread, solution wax and
hard wax
...
..
$\cdots$
.. 3300

Receivins pulleys, $3^{\prime \prime} \times 4^{\prime \prime}$ diameter, speed 350 to 500 revolutions per minute.
Belt.
Net weight.
Gross weight.
259 lbs.
Bench space.
$31^{\prime \prime} \times 12^{\prime \prime}$
Height.
3." round. 205 lbs.

Packing case measures $33^{\prime \prime} \times 24^{\prime \prime} \times 23^{\prime \prime}$. 


\section{Needles.}

\section{THE BRAND.}

$A \mathrm{~s}$ the results of experiments extending over some considerable time we have Machines.

The difference between the new and old needles is in the formation of the grooves, eyes and poinrs, together with a more careful testing of the steel from which the needles are made.

The superiority of our new needles is evidenced by their longer wear, and in the fact that a smaller needle may be used for the same size of thread than in any other make of needle; particularly is this the case when using flne thread.

Also, by the introduction of new and improved machinery, the production of some of these needles has been cheapened and we are able to offer them at a. lower price than formerly.

NOTE.-All onr needles are put "p in packets bearing our well-known Registered Trade Mark.

A1 Wax Thread Machine Needles

No.

No. 2 and "No. $5 \quad$ " " " . .

5

No. 6

No. 6

".

No. 4 Millband Machine Needles

.. $\quad \ldots$

Per Per

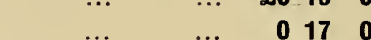

$1 / 2$

$\begin{array}{lll}\cdots & \ldots & \ldots\end{array}$

$\begin{array}{llll}0 & 18 & 0 & 1 / 8\end{array}$

.. $\quad$ sizes 3 to 7

$\begin{array}{llll}0 & 18 & 0 & 1 / 8\end{array}$

... $\quad$ sizes $7 \frac{1}{2}$ to 9

$\begin{array}{llll}1 & 1 & 0 & 2 / 0\end{array}$

",

$\cdots$

$\begin{array}{llll}1 & 17 & 6 & 3 / 3\end{array}$

Pilot Wax Thread Sewing Machine Needles

... $\quad$...

$111001 / 11:$

$\begin{array}{llll}0 & 15 & 0 & 1 / 4\end{array}$ 


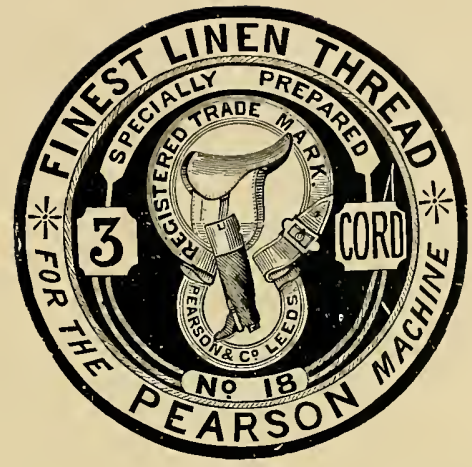

Machine Threads.

$\mathrm{T}$

HE best of Sewing Machines will fail to make good sewing if threads and needles of poor quality are used for them. The strength of the sewing depends upon the quality of the thread used, and it is not too much to say that the needle is the most important part of a sewing machine.

We are continually testing the quality of both needles and thread by using them in our machines and by other methods, and take every possible precaution to ensure stocking only those of the highest possible quality, and guarantee all our threads and needles to be of the best quality obtainable.

\section{Prices of "Saddle and Boot" Brand Threads.}

Black and Grey, 3 to 12 Cord.

\begin{tabular}{|c|c|c|c|c|c|c|}
\hline Number & 16 & 18 & 20 & 22 & 25 & 30 \\
\hline oz. $\mathrm{sp}$ & $44 /-$ & $46 /-$ & $48 /-$ & $51 /-$ & $54 /-$ & 58 \\
\hline Balls & $41 /-$ & $43 /-$ & $45 /-$ & $48 /-$ & $51 /-$ & 55 \\
\hline
\end{tabular}

Orange and Yellow Threads, $\mathbf{2}$ - per dozen pounds extra.

(Thread put up in $3 \mathrm{lb}$. packages.)

$\begin{array}{llllll}\text { No. } 3 \text { and } 4 \text { Cord } \ldots & \ldots & \ldots & \ldots & \frac{1}{4} \text { lb. Balls. } \\ \text { No. } 5,6 \text {, and } 7 \text { Cord } \ldots & \ldots & \ldots & \ldots & \frac{1}{2} & , \\ \text { No. } 8,9 \text {, and } 10 \text { Cord... } & \ldots & \ldots & \ldots & 1 & , "\end{array}$

\section{Millband Thread.}

10 to 20 Cord No. 18 in balls, soft spun $\quad \ldots \quad \ldots \quad 30 /-$ per doz, 1 bs.

on 5 Ib. cops, cabled ... $\quad \ldots \quad 33 /-$ 


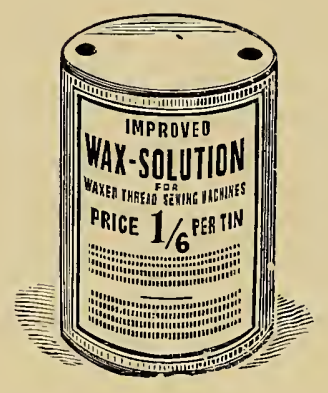

\section{Pearson's Wax Solution.}

For Wax Thread Sewing Machines, in Quart Tins at $1 / 6$.

This Solution has been manufactured by us as a Speciality for 30 years. It is: very rich in pitch and dries hand and waxlike.

\section{Pearson's Special Machine Oil.}

Put up in Quart Tins, for Sewing Machines.

Price $\quad \ldots \quad 1 / 6$.

\section{Machine Wax.}

For Whated Thread Sewing Machines.

Ordinary Brown Machine IVax in $28 \mathrm{lb}$, tins $\quad \ldots \quad \quad \ldots \quad \mathbf{2} \frac{1}{4} \mathrm{~d}$. per $1 \mathrm{~b}$.

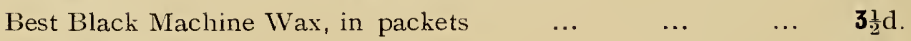

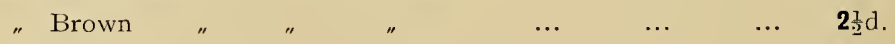

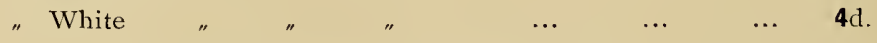

White Wax can be used with Black, White, or Coloured Threads. 


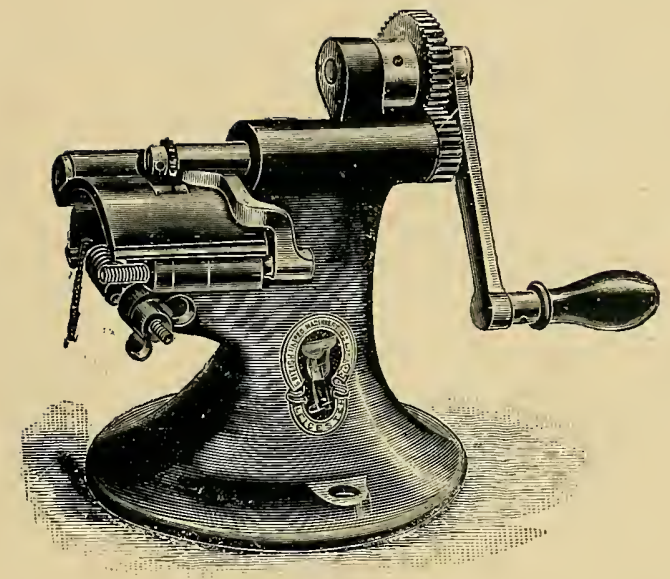

\section{New Model Stitch Pricking Machine.}

Х special feature of this machine is the small diameter of the prick wheels provided with an adjustable gauge to regulate the distance of the pricking from the edge, and will take any thichness of strap or trace, \&c. The prick wheel may be changed in a few seconds.

\section{Price (with one wheel) $\quad \ldots \quad £ 3 \mathbf{1 0} \quad \mathbf{0}$}

Prick wheels, 26 each.

Net weight. 42 lbs.
Gross wetsht.

60 lbs. Bench space.
$11^{\prime \prime} \times 7^{\prime \prime}$
Height. $9^{\prime \prime}$ 


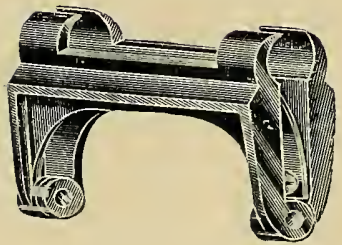

Iron Jaws for Round Reins.
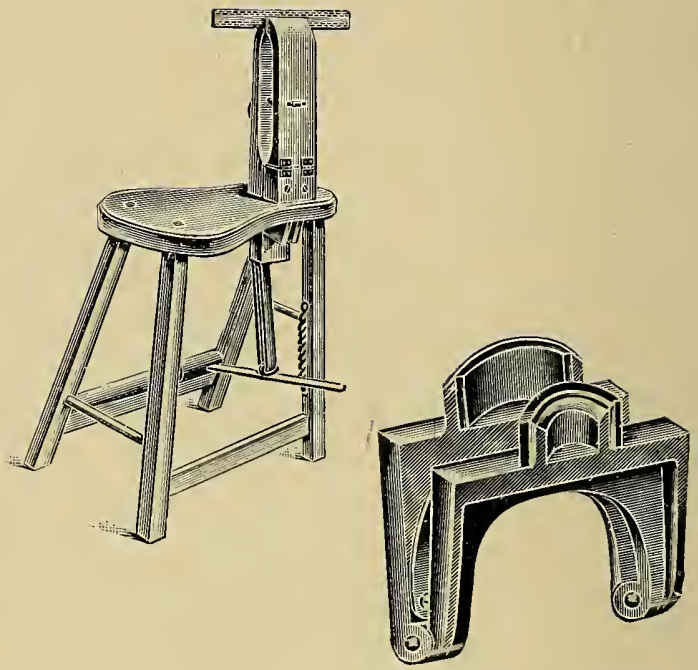

Iron Jaws for Shaft Tugs.

\section{Stitching Horse.}

STITCHING Horses are now in general use, and their superiority over old$\int$ fashioned clamps held between the knees is very evident. The work is held with a firm grip, and the workman is freed from the cramped position unavoidable when using knee clamps. The result is that more and better work can be done within a given time.

Price, complete as illustrated ...

" with side seat for women

" extra iron jaws for round reins, etc.

" extra iron jaws for shaft tuys
Net weisht.

$20 \mathrm{lbs}$.
Floor spac:.

$25^{\prime \prime} \times 17^{\prime \prime}$

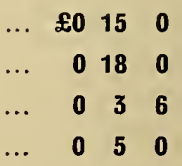

Height. $38^{\prime \prime}$ 


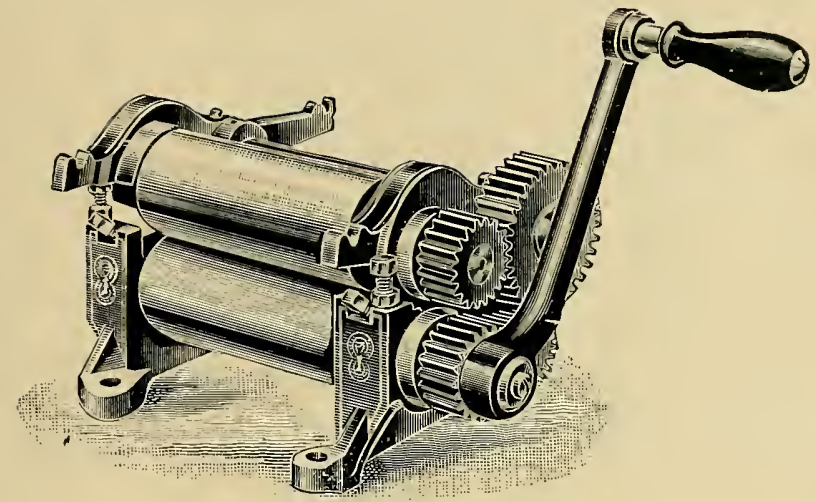

\section{Slicking Rolls.}

TRACES, straps, etc., are very much improved in appearance by being passed through these rolls after they have been sewn. The pressure is put on by means of a foot-lever. The arrangement of the wheels is such that any thickness of strap may be passed between the rolls without risk of the wheels being lifted out of gear with each other. The rolls are also used for graining small pieces of leather with fish-skin or copper plate.

Price, complete with treadle $\quad \ldots \quad \ldots \quad £ 400$

Net weight, 36 pounds. 


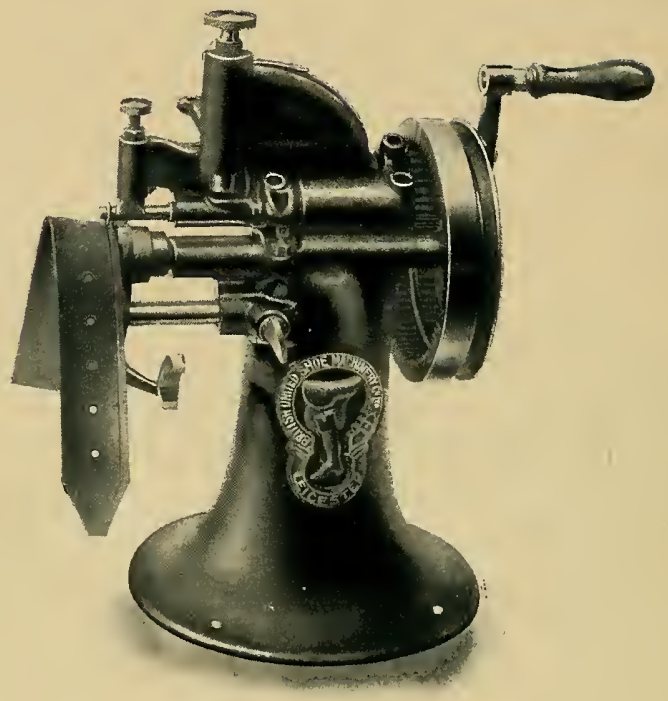

\section{No. 2 Wheel Creasing or Veining Machine:}

入 very decided improvement in creasing is obtained by using a machine with A a "live" creasing wheel as arranged in the machine illustrated. The crease wheel revolves at a greater speed than the feed roll, and thus produces a highly polished crease or vein. The machine is used for cycle saddles, gear cases, straps, brace ends, purses, \&c., \&c. The large gear wheel is grooved for power driving, or the machine may be turned by hand.

$$
\text { Price } \quad \ldots \quad \& 5 \quad 5 \quad 0
$$

Extra reining wheels, single, $1 /-$; double, $1 / 6$; treble, $2 /-$.

Note.-We carry a stock of single, double, treble, and bevel wheels in sizes

(1) fine; (2) medium; (3) coarse.

When ordering be particular to state size and style.

Net weight.

25 lbs.
Gross weight. $36 \mathrm{lbs}$.
Bench space.

$15^{\prime \prime} \times 11^{\prime \prime}$
Height. $15 \frac{1}{2} "$ 


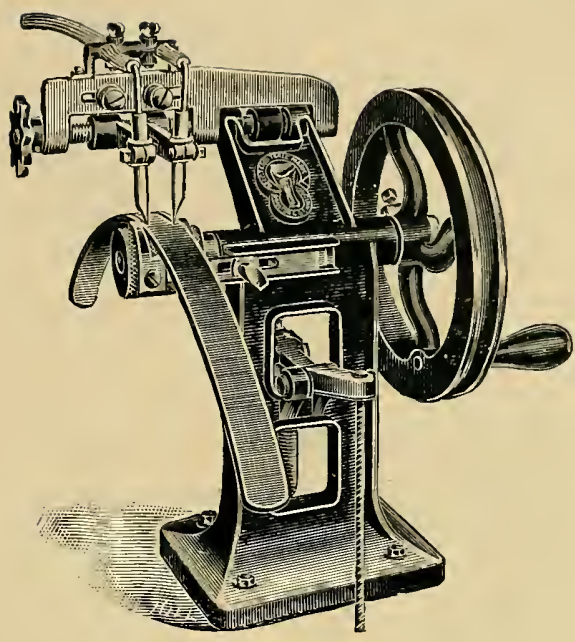

\section{Straight Iron Creasing or Veining Machine.} $\mathrm{B}_{\text {this machine. }}^{\mathrm{RACE} \text { ends, purses, rug straps, trunk straps, flat straps, etc., are creased on }}$

The creases are macle at any required distance from the edge, and for straight work, two or four crease or vein marks made be made simultaneously. Different kinds of veining irons can be used by changing the irons. Ornamental rollers, such as are used by trunk makers, are also used. The irons are heated by gas, each iron being provided with its own gas burner, and the temperature of the irons may be regulated to a nicety.

The heary hand wheel is groved so that the machine may be driven by power when required.

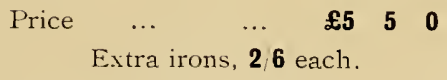

Note. When ordering veining irons be particular to state size and style. We carry a siock of single, double, treble, and berel, in sizes (1) fine;

(2) medium; (3) coarse.

\section{Osborne's Round Edge Creasing Machine.}

SIXGLE straps are run through this machine which forms a single crease on each edge, and at the same time rounds or moulds the edges. Admits straps

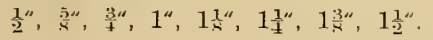

$$
\begin{array}{lllll}
\text { Price (without gas burner) } & \ldots & \text { \&5 } & \mathbf{0} & \mathbf{0}
\end{array}
$$

A similar machine for creasing stitched work, same dimensions and price.

$$
\begin{array}{lr}
\text { Net weight. } & \text { Gross weig } \\
\text { 4.2 lbs. } & 60 \mathrm{lbs} .
\end{array}
$$




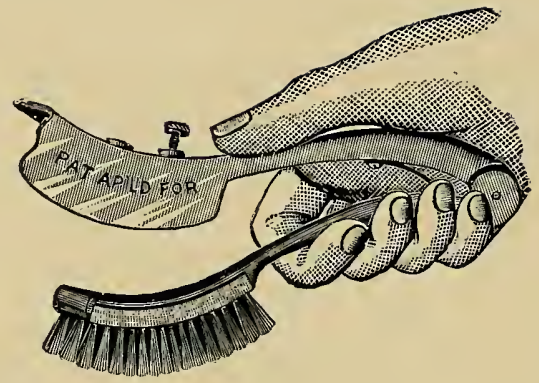

\section{Inking Brush with Guard.} HE guard springs away from the brush so that it is not soiled when the
brush is dipped in the ink or stain. The screw in the guard allows it to be adjusted so that more or less of the brush projects beyond the guard as may be required. By using the guard the ink is a pplied where it is wanted, and the adjacent parts are kept clean.

Price, complete $\quad \ldots \quad 5 /$ - each.

Re-fills, 6d, each.

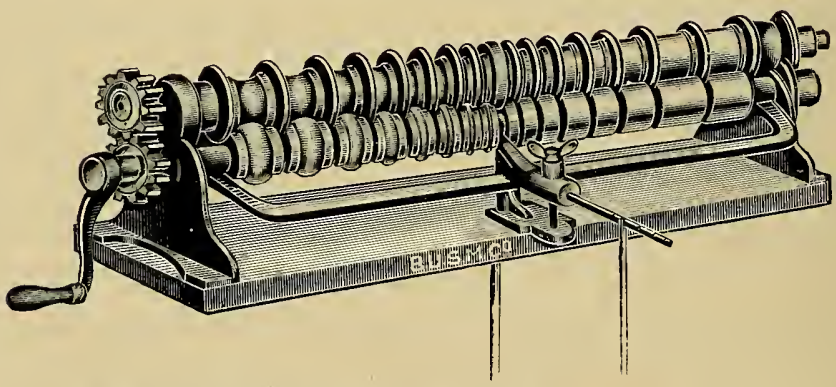

\section{Osborne's Creasing Machine.}

(Bellow's Patent.)

HE upper roll is of steel. One half is made for creasing flat straps of 1 various widths, and the other half is for rounded straps. The rolls for

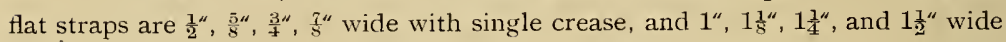
with double crease, and for rounded straps the same widths from $\frac{1}{2}$ " to $1 \frac{1}{2}$ " all arranged for double crease.

The lower roll is of wood, and presses the straps into the upper roll, the pressure being regulated by a treadle.

\begin{tabular}{|c|c|c|c|}
\hline & Price & $£ 6100$ & \\
\hline $\begin{array}{l}\text { Net weight. } \\
\text { to lbs. }\end{array}$ & $\begin{array}{c}\text { Gross weight. } \\
52 \text { lbs. }\end{array}$ & $\begin{array}{l}\text { Bench space. } \\
30^{\prime \prime} \times 15^{\prime \prime}\end{array}$ & $\begin{array}{l}\text { Height. } \\
11^{\prime \prime}\end{array}$ \\
\hline
\end{tabular}




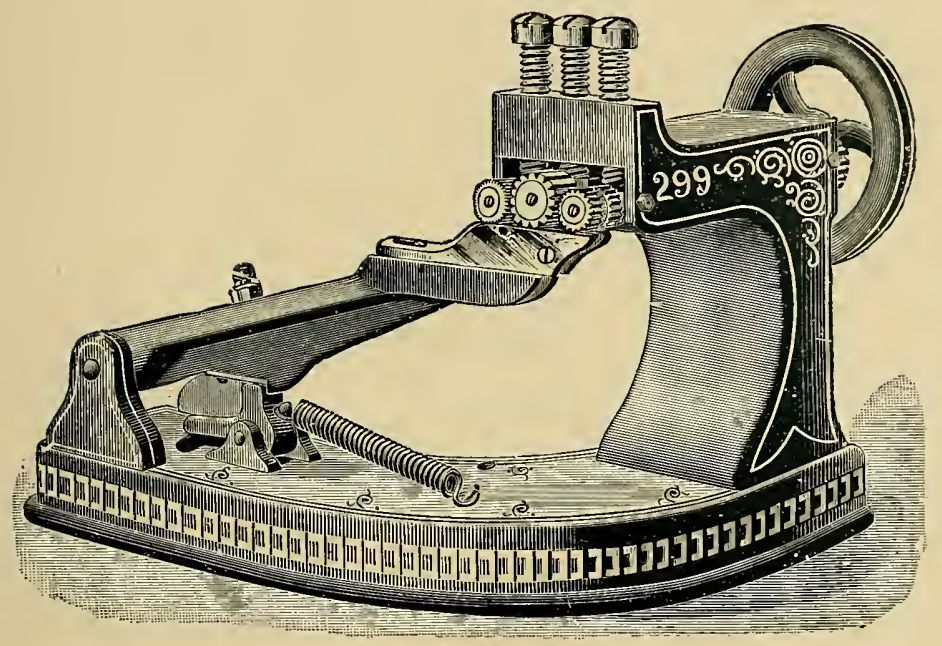

\section{Union Seam Finishing Machine.} $\prod \begin{gathered}\text { HIS machine cuts out welts and rubs down seams at one operaiion. It will } \\ \text { also rub down seams without a welt. Used by legging and football }\end{gathered}$ manufacturers.

$\begin{array}{clllllrrr}\text { Price of machine as illustrated... } & \ldots & \ldots & \ldots & \ldots & \text { £12 } & \mathbf{0} & \mathbf{0} \\ \text { Ditto } & \text { with power transmitter and driving pulley } & \ldots & \mathbf{1 3} & \mathbf{1 2} & \mathbf{0}\end{array}$ Receiving Pulley, $4_{2}^{1 / 4}$ grooved runs at 400 revolutions per minute.
Belt.
Net Weight.
Gross Weisht.
Bench Space.
Heisht.
s." round.
65 lbs.
90 lbs.
$1 S^{\prime \prime} \times 14^{\prime \prime}$
$12^{\prime \prime}$ 


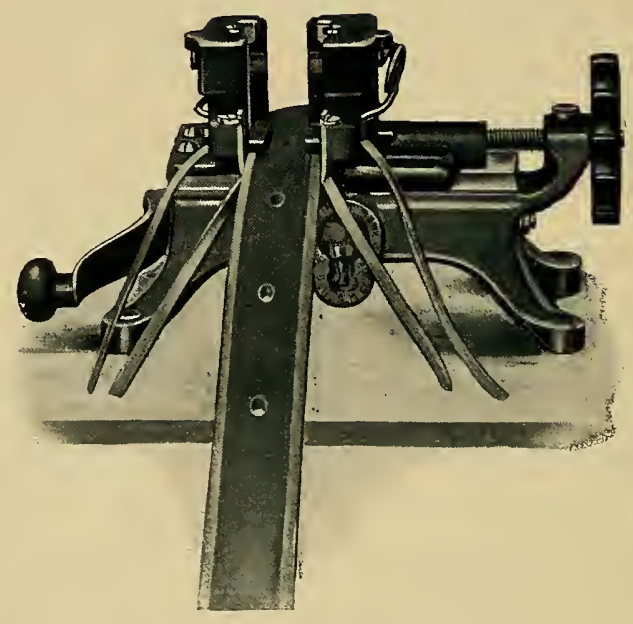

\section{Trace Trimming Machine.}

THE illustration shows how this machine is operated, the trace being pulled through it by hand.

The four corners are trimmed simultaneously, and the knives are adjustable so that more or less is taken off the corners as may be required.

The knives automatically adjust themselves to suit different thicknesses of traces, backbands, straps, etc., and the adjustment for different widths is readily obtained by means of the hand-wheel and screw.

Spring adjusting devices cause the knives to accommodate themselves to any little variation either in thickness or width, so that the same amount of trimming is done notwithstanding such slight irregularities.

$$
\begin{array}{lllll}
\text { Price } & \ldots & £ 4 & 0 & 0
\end{array}
$$

Extra knives, per set

Net Wetght.

$9 \frac{1}{2} \mathrm{lbs}$.
Gross Weight.

16 lbs.

$$
\text { 6. } 6 /-
$$

Bench Space. $12^{\prime \prime} \times 6 \frac{11}{2}$

Height. $6 \frac{11}{2}$ 


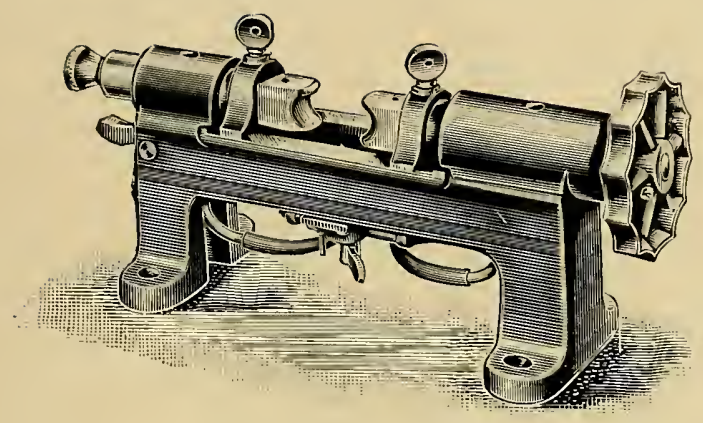

\section{Trace Burnishing Machine.}

JSED in conjunction with the Trace Trimmer. Burnishing irons supplied shape of edge which may be required. The irons are readily changed, and are heated by specially designed gas-jets. Both edges are burnished together. The adjustment for different widths is very readily made.

A spring adjusting device causes the burnishing irons to accommodate themselves to any little irregularity in the vidth of the straps, etc., so that all parts of the edges are burnisned under equal pressure.

Price, complete with one pair of irons

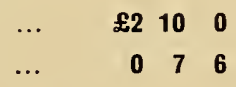

Extra irons, per pair

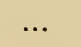
...
Bench Space. $14^{\prime \prime} \times 4^{\prime \prime}$

Net Weight.

9 lbs.
Gross Weight. 16 lbs.
Height. $6^{\prime \prime}$ 


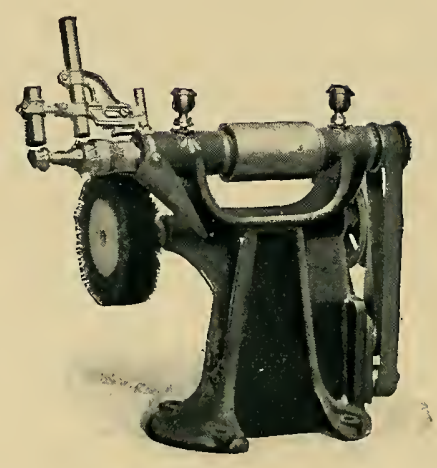

\section{Rotary Bench Edge Setting Machine.}

FOR finishing edges in a satisfactory manner at a low cost this machine - cannot be excelled. The edge irons run at a high speed, and no gas is. required, as the heat is obtained by friction. The brush is run at a much slower speed, which enables the operator to get a finished edge without risk of brushing: off the wax and destroying the polish.

A wax-holder for stick wax can be supplied for this machine if required.

$$
\text { Price } \quad \ldots \quad £ 410 \quad 0
$$

Receiving pulley, $3^{n} \times 2 \frac{11}{1}$, runs at 2,000 revolutions per minute.

$\begin{array}{ccccc}\text { Belt. } & \text { Net Weight. } & \text { Gross Weight. } & \text { Bench Space. } & \text { Height.. } \\ 2^{\prime \prime} & 75 \text { lbs. } & 90 \text { lbs. } & 21^{\prime \prime} \times 12^{\prime \prime} & 22^{\prime \prime}\end{array}$




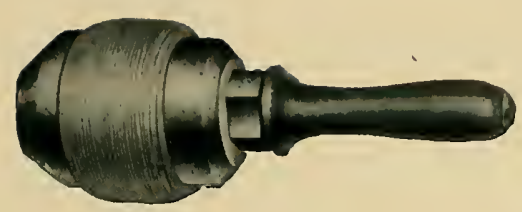

\section{Raw Hide Mallets.}

$1 \frac{10}{16} \mathrm{lb} .2 \mathrm{lb} . \quad 3 \frac{1}{4} \mathrm{lbs} . \quad 4_{4}^{3}$ lbs. $6 \frac{1}{4}$ lbs. $8 \frac{1}{2} \mathrm{lbs} . \quad 10 \mathrm{lbs} .12 \mathrm{lbs} .14 \mathrm{lbs}$.

$5 /-\quad 7 /-\quad 9 /-\quad 11 /-\quad 13 /-\quad 15 /-\quad 17 /-\quad 19 /-21 /-$

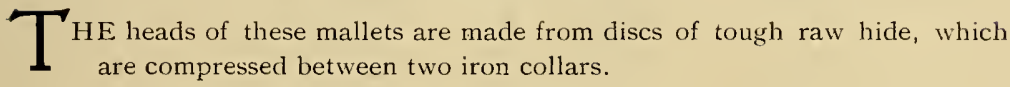

The discs of which the handles are made are cut from tanned leather, and there is a solid steel core running right through the handle and head.

To ensure solidity each mallet is subjected to a pressure of fifty tons.

The result is these mallets will withstand any amount of hard work, and will last for many years.

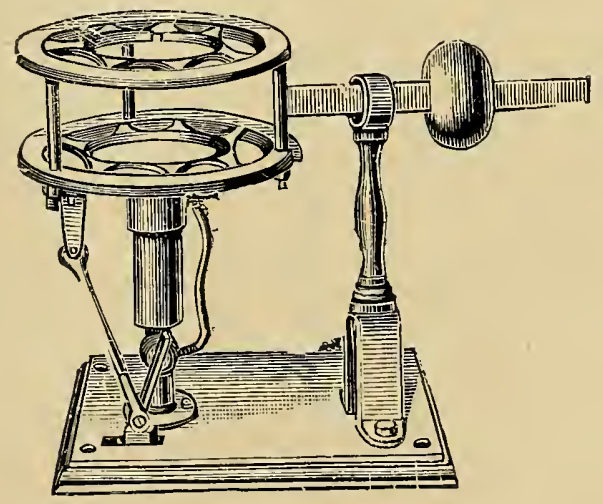

\section{Atmospheric Gas Heaters.}

FOR Hand Tools. This appliance turns off the gas as soon as the tool is taken from the flame, and re-lights it when the tool is again laid on. Saves its cost in gas in a short time.

$\begin{array}{rlr}\text { Frice } & \ldots & \mathbf{1 0 / 6} \\ \text { Weight } & \ldots & 14 \text { lbs. }\end{array}$


BRITISH UNITED

SHOE MACHINERY Co., Ltd.,

LEICESTER.

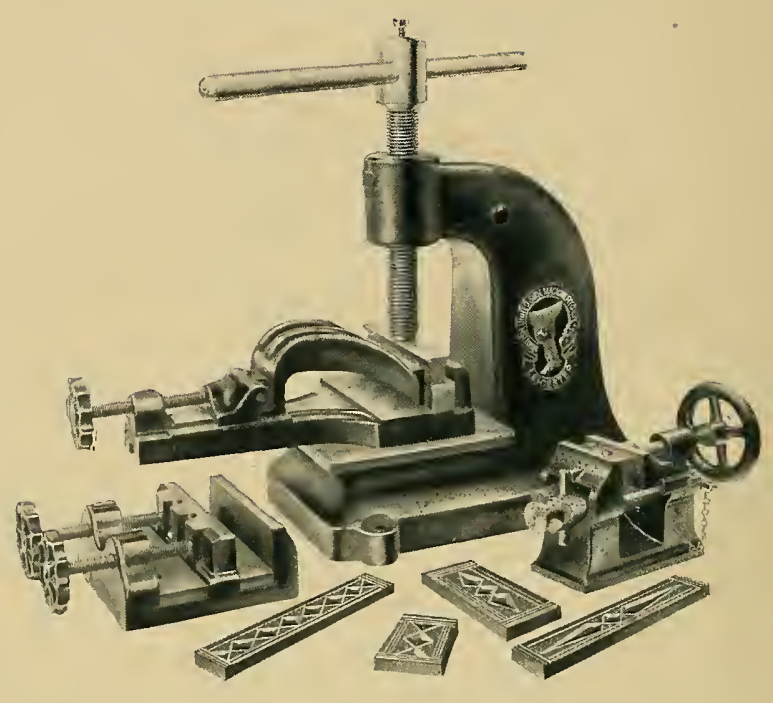

\section{Harness Loop Creasing Outfit.} HE pipe loops are stitched into the harness in the same way as would be-
done for hand-creasing; the dies, which are made of gun metal, are used either cold or hot. Heated dies make better and more lasting impressions.

Press, with three iron die blocks and two side plates $\quad \ldots \quad \ldots \ldots$ \&4 10

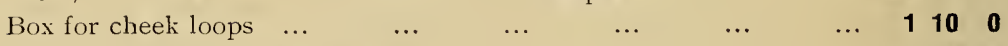

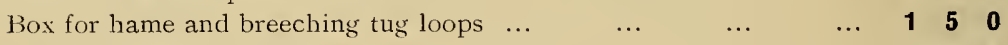

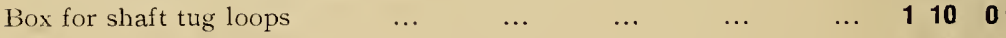

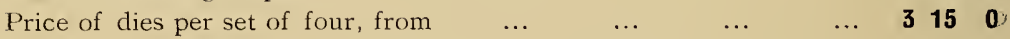

$$
\text { Net weight, complete } \quad \ldots \quad 280 \text { pounds. }
$$



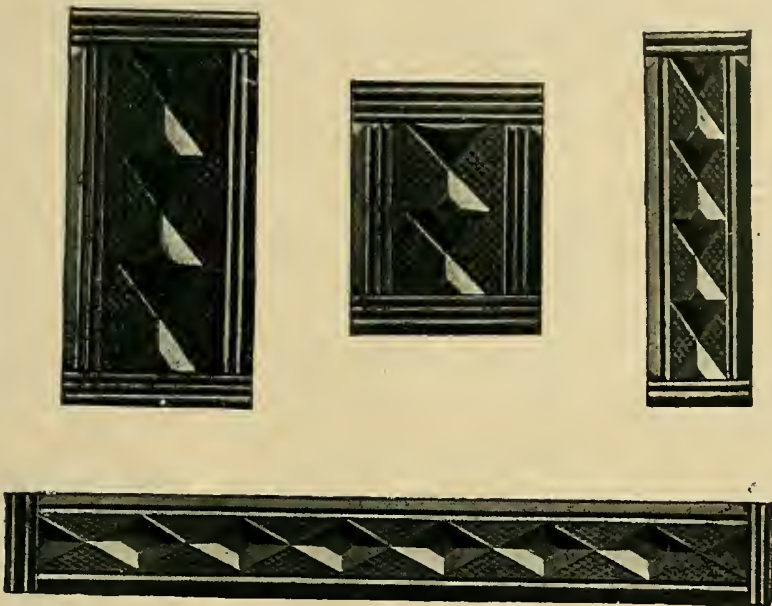

\section{Harness Loop Dies-Gun Metal.}

The following are always kept in stock:-

\section{Diamond Pattern.}

\begin{tabular}{|c|c|c|c|c|c|c|c|c|c|c|c|c|}
\hline$\frac{5}{8} " \times 5 \frac{1}{2}$ & $\cdots$ & $\cdots$ & $\ldots$ & $£ 018$ & 0 & $14^{1 \prime \prime} \times 3^{\prime \prime}$ & $\ldots$ & & & & 031 & \\
\hline$\frac{50}{8} \times 3 \frac{1}{4} "$ & $\cdots$ & $\cdots$ & $\cdots$ & 017 & 0 & $1_{3}^{3}{ }^{3 \prime} \times 2^{\prime \prime}$ & $\cdots$ & $\cdots$ & & & 01 & \\
\hline$\frac{3}{7} " \times 7^{\prime \prime}$ & $\cdots$ & $\ldots$ & $\ldots$ & 10 & 0 . & $13^{3 \prime} \times 3 \frac{1}{2} "$ & $\cdots$ & $\ldots$ & & & & 0 \\
\hline$\frac{33}{4} \times 3 \frac{11}{2}$ & $\cdots$ & $\ldots$ & $\ldots$ & 017 & 0 & $1 \frac{1}{2} " \times 3 \frac{3}{4}$ & 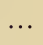 & $\ldots$ & & & & 0 \\
\hline $\mathrm{x} 4^{\prime \prime}$ & $\ldots$ & $\ldots$ & $\ldots$ & 018 & 0 & $1 \frac{1}{2} " x=23$ & $\ldots$ & $\cdots$ & & & 01 & 9 \\
\hline$\frac{1 " 1}{11} \times 1 \frac{3}{4}$ & $\ldots$ & $\ldots$ & $\ldots$ & 017 & 0 & $1 \frac{1}{2}{ }^{\prime \prime} \times 7^{\prime \prime}$ & & $\ldots$ & & & 1 & 6 \\
\hline
\end{tabular}

Send for impressions in leather from above dies.

Special Pattern dies made to order at an extra cost of from $15 \%$ to $30 \%$ on above prices. 

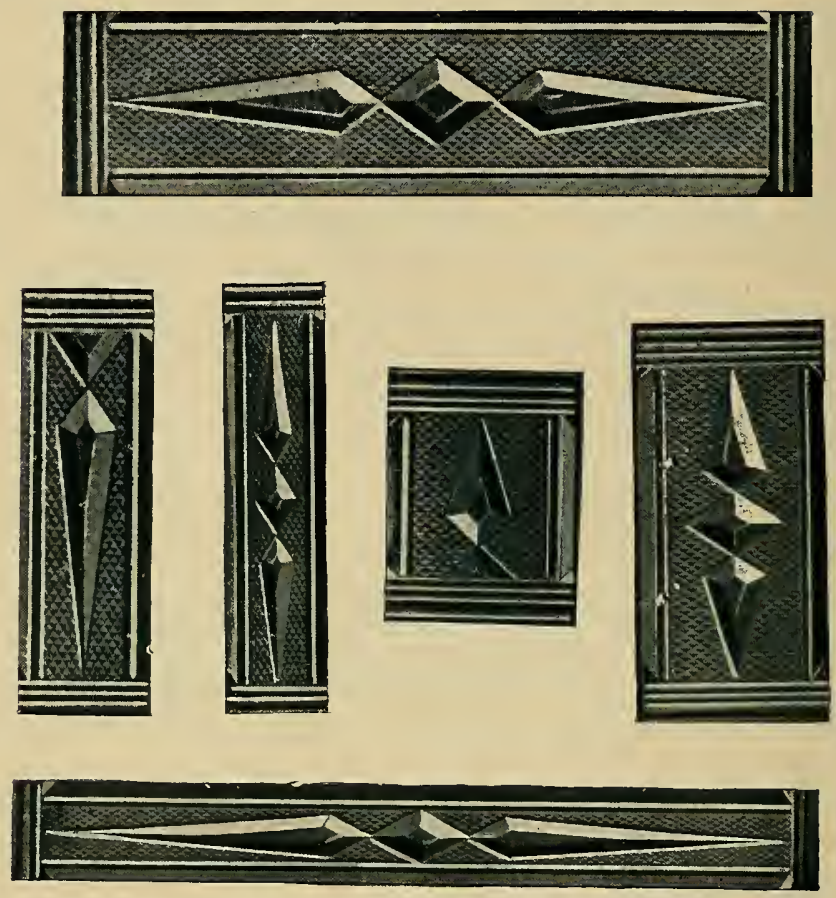

\section{Harness Loop Dies-Gun Metal.}

The following are always kept in stock:-

\section{Spear and Diamond Pattern.}

\begin{tabular}{|c|c|c|c|c|c|c|c|c|c|c|c|c|}
\hline$\frac{5}{8} " x 5 \frac{1}{2} "$ & $\ldots$ & $\cdots$ & $\ldots$ & $£ 0$ & & 0 & $1_{\frac{17}{1}}^{\prime \prime} \times 1_{\frac{3}{4}}^{\frac{3}{\prime \prime}}$ & $\ldots$ & $\ldots$ & $\ldots$ & 201 & 170 \\
\hline$\frac{5}{5} " \times 3 \frac{1}{4} "$ & $\ldots$ & $\ldots$ & $\ldots$ & 0 & 17 & 0 & $1 \frac{11}{4} \times 3^{\prime \prime}$ & $\ldots$ & $\ldots$ & $\ldots$ & & 18 \\
\hline$\frac{54}{4} \times 7 \frac{1}{2} "$ & $\ldots$ & $\ldots$ & $\ldots$ & & 0 & 0 & $13{ }^{\prime \prime} \times 2^{\prime \prime}$ & $\ldots$ & $\ldots$ & $\ldots$ & 0 & 18 \\
\hline$\frac{3}{4} " x 4^{\prime \prime}$ & $\cdots$ & $\ldots$ & $\cdots$ & & 18 & 0 & $1 \frac{5}{8} " x 3 \frac{11}{2}$ & $\ldots$ & $\ldots$ & $\ldots$ & 1 & 0 \\
\hline$\frac{3}{t} " x 6 \frac{1}{2} "$ & $\ldots$ & $\ldots$ & $\ldots$ & 0 & 18 & 0 & $1 \frac{1}{2} " \times 2 \frac{3}{3} "$ & $\ldots$ & $\ldots$ & $\ldots$ & 01 & 19 \\
\hline$\frac{3}{4} " x 3 \frac{1}{2} "$ & $\ldots$ & $\ldots$ & .. & 0 & 17 & 0 & $1 \frac{1}{2} " x 3_{4}^{3 / \prime}$ & $\ldots$ & $\ldots$ & $\ldots$ & 1 & 0 \\
\hline$I^{\prime \prime} \quad x t^{\prime \prime}$ & ... & $\ldots$ & $\ldots$ & 0 & 18 & 0 & $1 \frac{1}{2} " \times 7^{\prime \prime}$ & $\ldots$ & $\ldots$ & $\ldots$ & 1 & 6 \\
\hline
\end{tabular}

Send for Impressions in leather from above Dies.

Special Pattern dies made to order at an extra cost of from $15 \%$ to $30 \%$ on above prices. 


\section{Blind or Winker Moulds.}
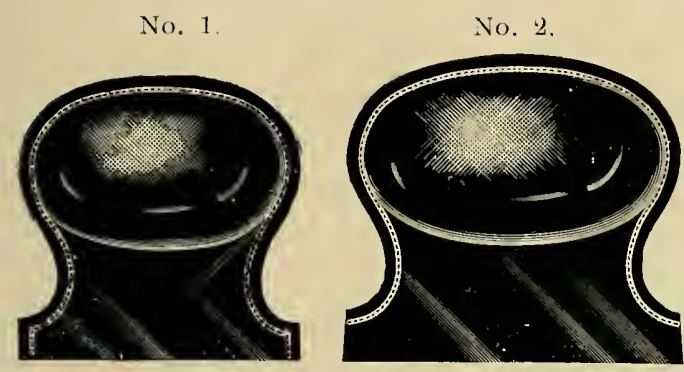

Small Sensible Blind. Large Sensible Blind.

No. 4.

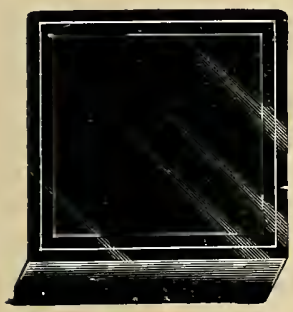

Square Blind.
No. 5.

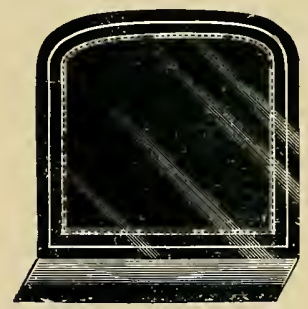

Rounded Blind.

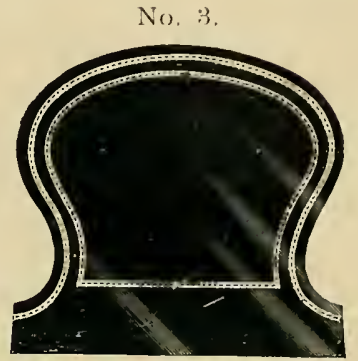

Hatchet Blind (large).
No. 6.

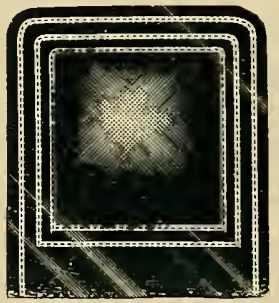

Round Corner Blind.
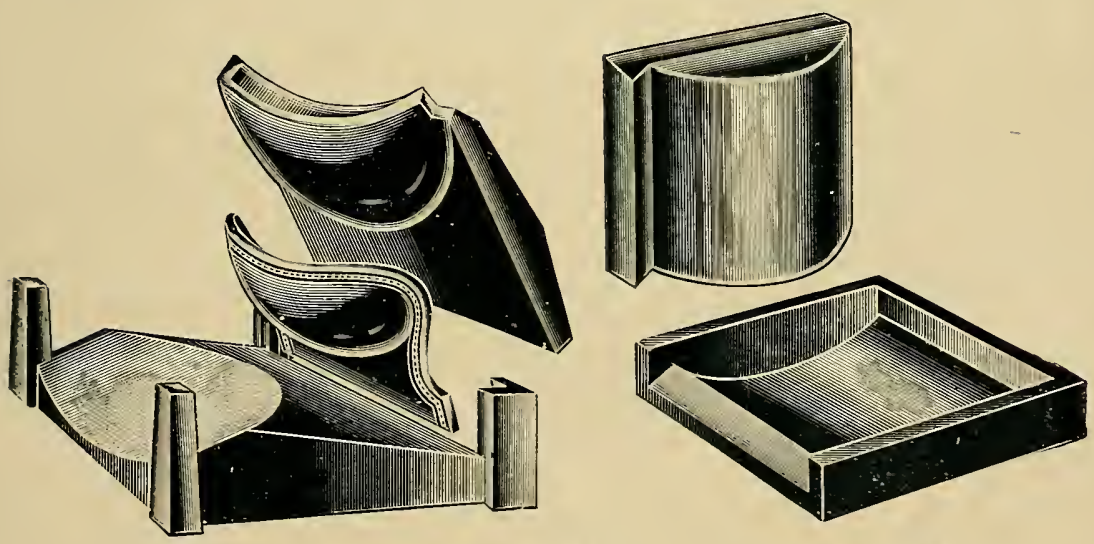

Prices: No. 1, 20/-.

No. 2,226

No. $3,4.5,6,25$-.

Any style or size of Mould rade to order. 


\section{BRITISH UNITED \\ SHOE MACHINERY Co., Ltd., LEICESTER.}

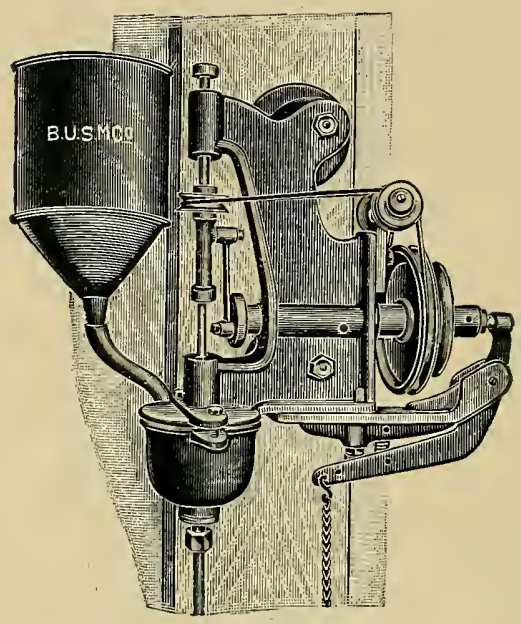

\section{Dock Stuffing Machine.}

入 large hopper contains the main supply of seed which flows by gravitation

into the small hopper through which the stuffing rod works. By this arrangement a shorter, and therefore stiffer stuffing rod is used than when the rod has to work through a large hopper.

The stuffing rod is held in position by a screw, and can be readily withdrawn from the machine on loosening the screw without disturbing any other part of t'se machine.

The machine is usually fixed to a wooden column or to a stout plank fixed vertically, or it may be fixed to a brick column.

$$
\text { Price, without column } \quad \ldots \quad \begin{array}{lllll}
\mathbf{0} & \mathbf{0}
\end{array}
$$

Receiving grooved pulley, $4^{\prime \prime}$ diameter, runs at 800 revolutions per minute. 


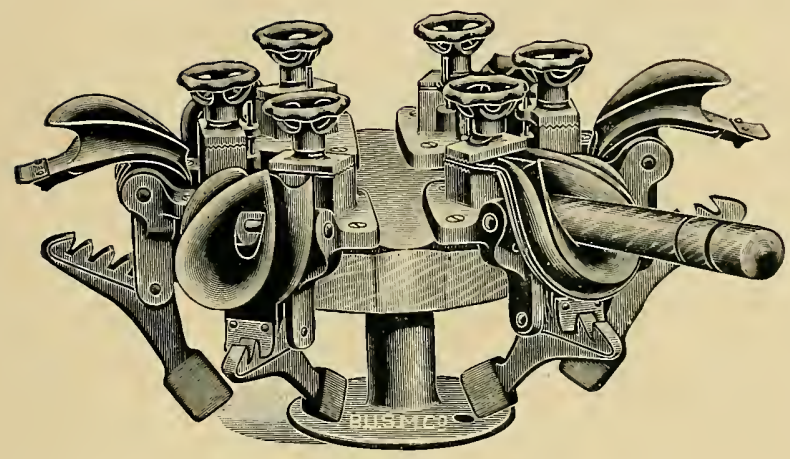

\section{Dock Forming and Stretching Machine.}

SIX Dock Formers and Stretchers are mounted on a revolving table, but each

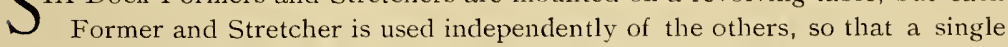
dock, or any number up to six, may be moulded. Each mould or former is so made as to impart a perfect shape to each dock. After clamping the points, the stretching is done instantly by a lever.

Price, six Formers on a revolving table

Price, single Former, to fix on bench

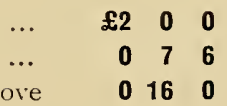

Price, two Formers of different pattern to above

$\begin{array}{lll}0 & 16 & 0\end{array}$ 


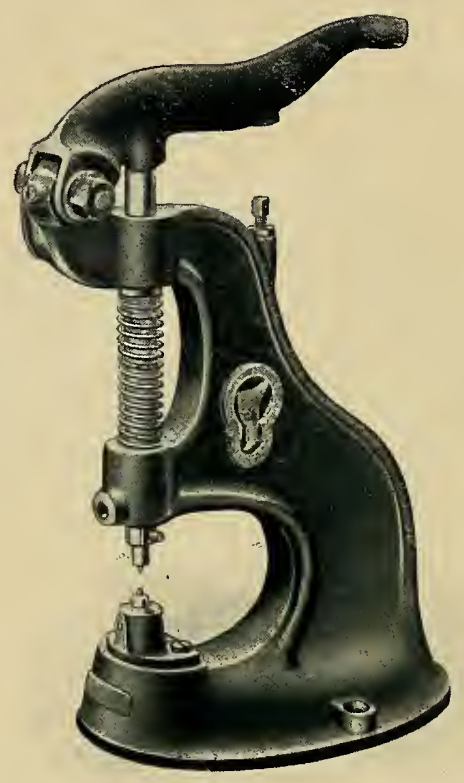

\section{Punching and Eyeletting Machines.}

No. 1 Machine, to punch $4^{\prime \prime}$ from edge

No. 2 ,

No. 3 ,

No. 1 ,

No. 2 ,

No. 3 ,

Twin Punching and Self-Feeding

Automatic ditto, for power

\begin{tabular}{|c|c|c|c|c|}
\hline$\ldots$ & $\ldots$ & $\ldots$ & £o & 14 \\
\hline$\cdots$ & $\ldots$ & $\ldots$ & 1 & 5 \\
\hline . & $\ldots$ & $\ldots$ & 1 & 10 \\
\hline & $\ldots$ & $\ldots$ & 0 & 14 \\
\hline & $\ldots$ & $\ldots$ & 1 & 5 \\
\hline & $\ldots$ & $\ldots$ & 1 & 10 \\
\hline . & $\ldots$ & $\ldots$ & 4 & 10 \\
\hline Machine & $\ldots$ & $\ldots$ & 12 & 0 \\
\hline & & $\ldots$ & 35 & 0 \\
\hline
\end{tabular}

Any of the above machines can be adapted for special work.

When ordering Eyeletting Machines, send about 200 eyelets, or for Self-Feeding Machines about 1,000 eyelets, so that the dies and səlf-feeding parts may be made to suit them. 


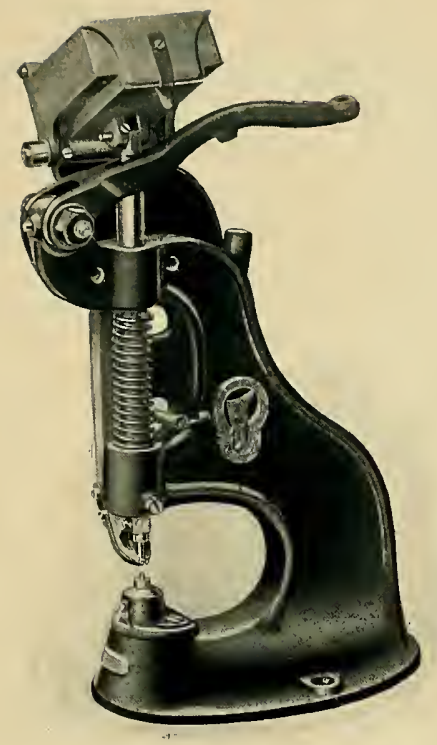

\section{Self-Feeding Eyeletting Machine.}

$\prod_{\text {HIS is a small fcot-Fower Eyeletting Machire suitable fcr braces, }}^{\text {purses, etc. }}$

$$
\text { Frice } \quad \ldots \quad £ 410 \quad 0
$$

Net Weight.

25 lbs. Gross Weight.
$50 \mathrm{lbs}$. Bench 5 pace.
$5{ }_{2}^{1 .} \times 9^{\prime \prime}$ 


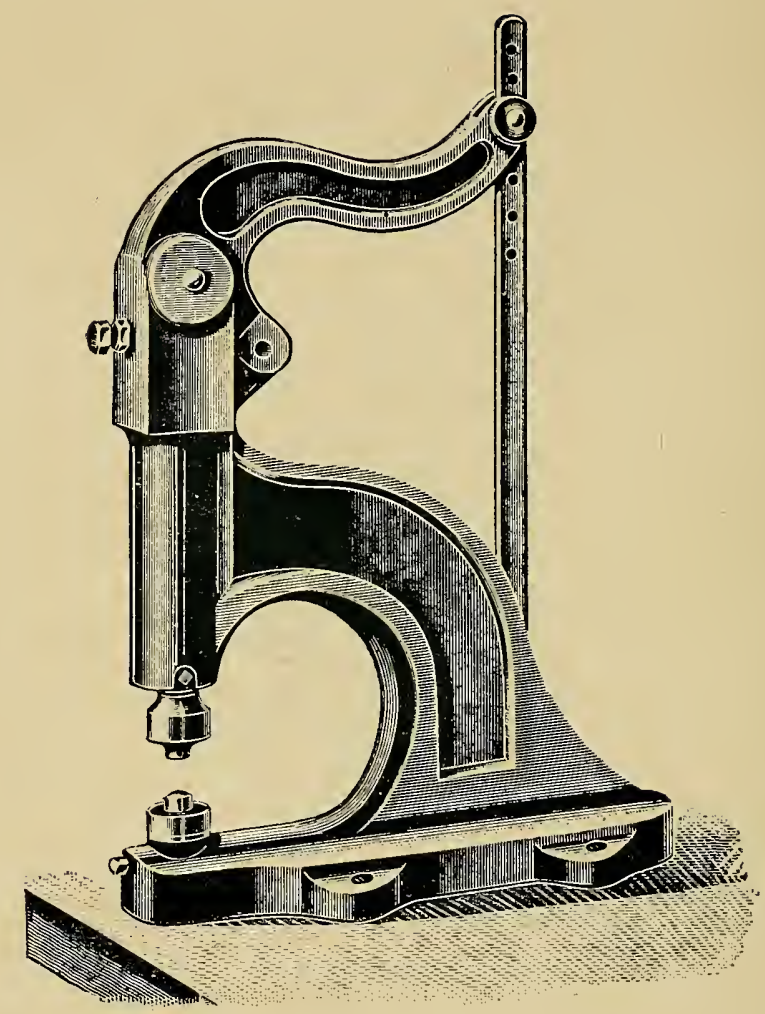

\section{"Excelsior" Eyeletting Machine.}

For Closing Sack or Sail Eyelets.

Price, complete with treadle, adjustable Iron Rod, and one set of

Extra sets of Dies from $\mathbf{1 0 / 6}$ per set.

Punching Dies can also be fitted to this machine. 


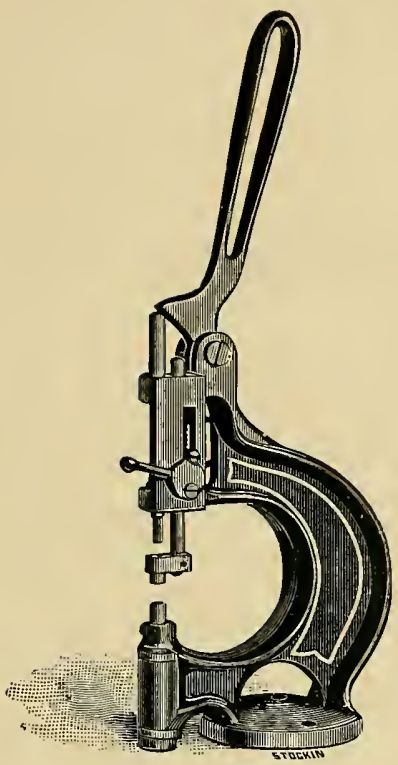

\section{American Standard Patent Rivetting Machine.}

$\mathrm{T}$

HE Standard Patent Rivetting Machines are the Good, Quick, and cheap. They are easily operated, and being simple in construction are not likely to get out of order. The machines automatically adjust themselves to suit varying thicknesses of material.

The Standard Rivetters have met with an unprecedented success in America, and are extensively used by harness makers, saddlers, horse clothing manufacturers, and by manufacturers of leather goods of every description. They are also largely used for splicing and repairing belts, straps, harness, and all sorts of leather goods.

The machines are made to drive and clench rivets or studs with heads either $\frac{33}{16}$ " or $\frac{1}{1}$ " diameter and with any length of prong up to $\frac{1}{2}$.

Hand Machine for rivets Hand Machine for studs ... $\quad$ - $\quad$.. Foot Lever Machine, for rivets, spots or studs ... Extra set of tools, dies, etc., for other sizes, per set

\begin{tabular}{|c|c|c|c|}
\hline$\ldots$ & $\ldots$ & $£ 1$ & 5 \\
\hline 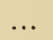 & & 11 & 12 \\
\hline & & 21 & 10 \\
\hline & & 1 & 0 \\
\hline
\end{tabular}




\section{Standard Patent Rivets and Studs.}

RIVET.

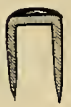

Fig. 1.
RIVETTED.

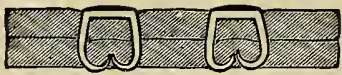

Fig. 2.
RIVETTED。

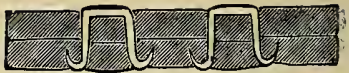

Fig. 3.

$F^{1}$ GURE 1 shows the Standard Patent Rivet before, and Figures 2 and 3. after being rivetted. Figure 2 shows the inward clinch, and Figure 3 the outward clinch. Either style of clinch, inward or outward, can be immediately obtained by changing the anvils in the rivetting machine.

The following are some of the advantages claimed for these rivets :-

They are made of the finest quality of STEEL, leave a perfectly smooth surface on the under side when rivetted, and cut out no material in driving.

They adapt themselves to material varying in thickness, drive through the toughest material, are strong enough for all purposes, and are cheap and good.

For joining straps, belts, harness, etc., these rivets surpass anything yet invented; they are invaluable to makers of leather goods. For some work these rivets are superior to thread, being much stronger, capable of standing severer strain, and are unaffected by the weather. They are driven by hand, foot or power machines, or may be driven with a hammer, and make a perfectly smooth inside.

For attaching straps and buckles to horse clothing, harness, leggings, portmanteaus, and leather goods of every description, these rivets bave no superior.

\section{Prices of the Standard Patent Rivets.}

\begin{tabular}{|c|c|c|c|c|c|}
\hline \multirow{2}{*}{$\begin{array}{c}\text { Diameter } \\
\text { of } \\
\text { Head. }\end{array}$} & \multirow{2}{*}{$\begin{array}{l}\text { Lensth } \\
\text { of } \\
\text { Prong. }\end{array}$} & \multirow{2}{*}{ Japanned. } & \multicolumn{3}{|c|}{ Per $1,000}$. \\
\hline & & & $\begin{array}{l}\text { Coppered } \\
\text { or Tinned. }\end{array}$ & Brassed. & Nickeled. \\
\hline $3-16^{\prime \prime}$ & $4-16^{\prime \prime}$ & $1 / 5$ & $1 / 6$ & $1 / 6$ & $1 / 9$ \\
\hline $3-16^{\alpha}$ & $5-16^{\prime \prime}$ & $1 / 5$ & $1 / 6 \frac{1}{2}$ & $1 / 7$ & $1 / 9 \frac{1}{2}$ \\
\hline $4-16^{\prime \prime}$ & $4-16^{\prime \prime}$ & $1 / 5$ & $1 / 6$ & $1 / 7$ & $1 / 9 \frac{1}{2}$ \\
\hline $4-16^{\prime \prime}$ & $5-16^{\prime \prime}$ & $1 / 7 \frac{1}{2}$ & $1 / 8 \frac{1}{2}$ & $1 / 9$ & $2 /-$ \\
\hline $4-16^{\prime \prime}$ & $6-16^{\prime \prime}$ & $1 / 7_{2}^{1}$ & $1 / 9$ & $1 / 10 \frac{1}{2}$ & $2 / 0 \frac{1}{2}$ \\
\hline $4-16^{\prime \prime}$ & $8-16^{\prime \prime}$ & $2 / 0 \frac{1}{2}$ & $2 / 1 \frac{1}{2}$ & - & 一 \\
\hline
\end{tabular}

Send for Samples of Rivets and Work. 


\section{Standard Patent Studs.}
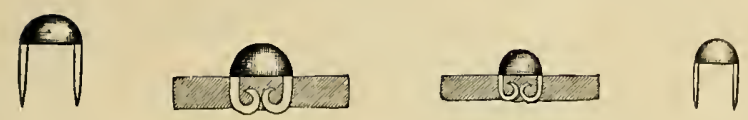

$\mathrm{W}^{1}$

ITH round heads for ornamenting dog collars, children's shoes, and all kinds of fancy leather work. The prongs of these studs can be turned inwards or outwards, leaving the under side perfectly smooth. They are similar to the Standard Rivets, but have a rounded head.

They are made in two size of heads, viz. :- ${ }^{i 1 i^{\prime \prime}}$ and $\frac{1 "}{4 \prime}$.

\section{Prices of Patent Studs.}

Brass or Nickelled.

Diam. of Head.

$3-16^{\prime \prime}$

Length of Prong.

$3-16^{\prime \prime}$

\begin{tabular}{lllll}
$\ldots$ & $3-16^{\prime \prime}$ & $\ldots$ & $\ldots$ & $\ldots$ \\
$\ldots$ & $4-16^{\prime \prime}$ & $\ldots$ & $\ldots$ & $\ldots$ \\
$\ldots$ & $4-16^{\prime \prime}$ & $\ldots$ & $\ldots$ & $\ldots$ \\
\hline
\end{tabular}

$4-16^{\prime \prime}$

$4-16^{\prime \prime}$

$\cdots$

2/9 per 1,000

\section{Large Spots or Studs.}

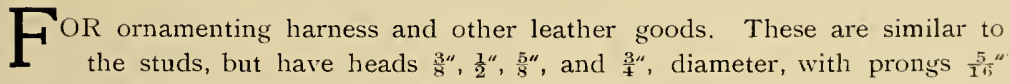
long. There are two shapes of head-half-round, and nearly flat with round edges.

Prices per 1,000.

\begin{tabular}{|c|c|c|c|c|c|}
\hline$\frac{3}{2}$ & ead & brass & $\ldots$ & $\ldots$ & $7 / 6$ \\
\hline$\frac{1}{2} "$ & $"$ & , & . & $\ldots$ & $8 / 6$ \\
\hline$\frac{5}{8} 4$ & , & , & $\cdots$ & $\cdots$ & $11 /-$ \\
\hline$\frac{3}{4}$ & , & ", & $\ldots$ & $\ldots$ & $15 / 3$ \\
\hline$\tau^{\prime \prime \prime}$ & ", & ", & • & $\cdots$ & 22 \\
\hline $1^{\prime \prime}$ & , & , & $\ldots$ & $\ldots$ & 249 \\
\hline
\end{tabular}

\begin{tabular}{|c|c|c|c|c|}
\hline$\frac{3}{8} \cdot 1$ & ad, & err & ilv & 99 \\
\hline$\frac{1}{2} "$ & " & , & ," & $12 / 3$ \\
\hline$\frac{5}{8} "$ & , & , & ", & 18 - \\
\hline$\frac{3}{4}{ }^{4}$ & , & " & , & $22 /-$ \\
\hline$\frac{7}{S}{ }^{\prime \prime}$ &. & $"$ & $"$ & 319 \\
\hline $1^{\prime \prime}$ & , & ,. & ,, & 363 \\
\hline
\end{tabular}

Extra sets of tools required for each shape and size of head, at $£ 1$.

Send for Samples of Studs, Spots and Work. 


\section{Tubular Rivet Setting Machines.}

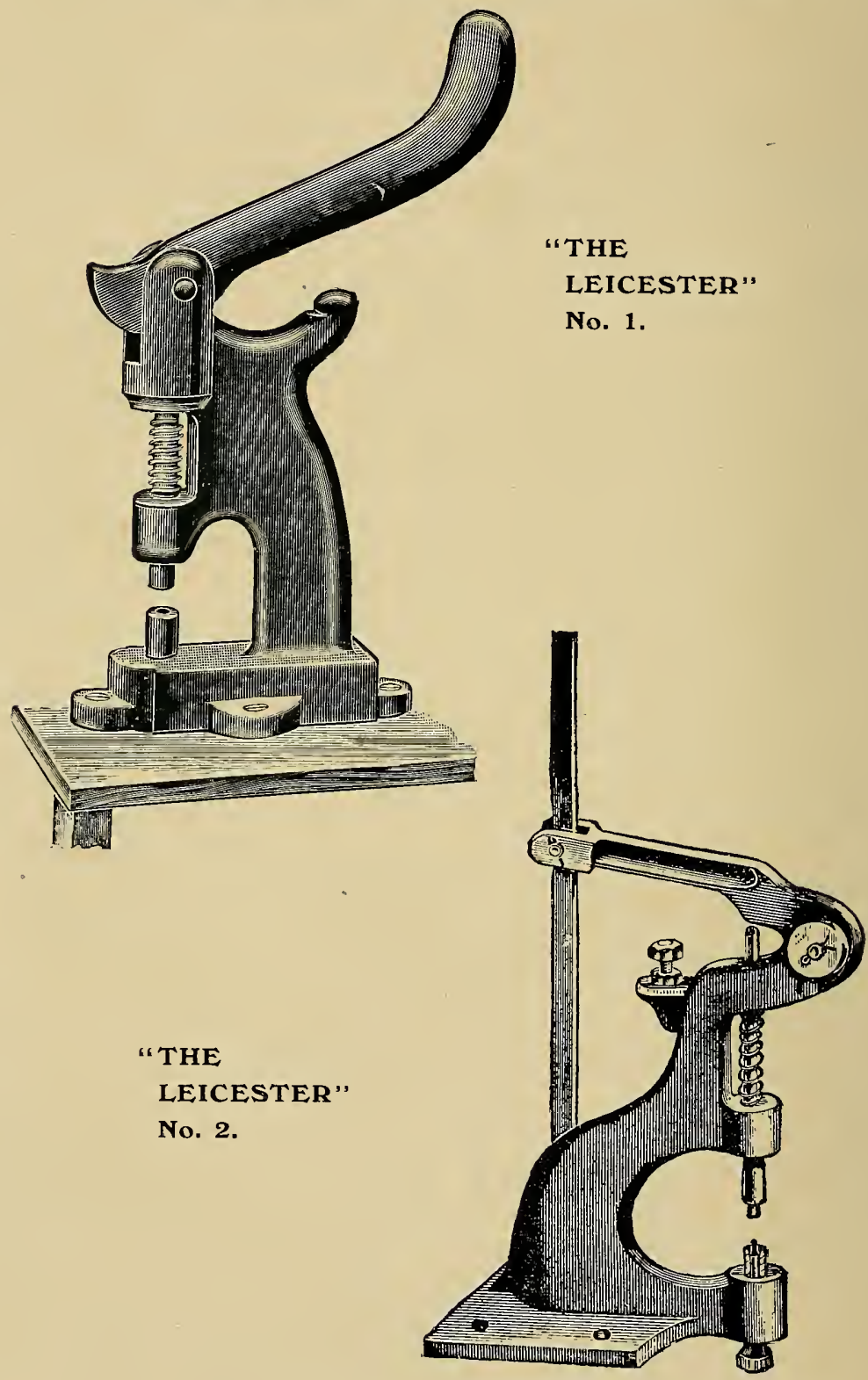

Prices of Machines ON APPLiCATION. 


\section{Tubular Rivet Setting Machines.}

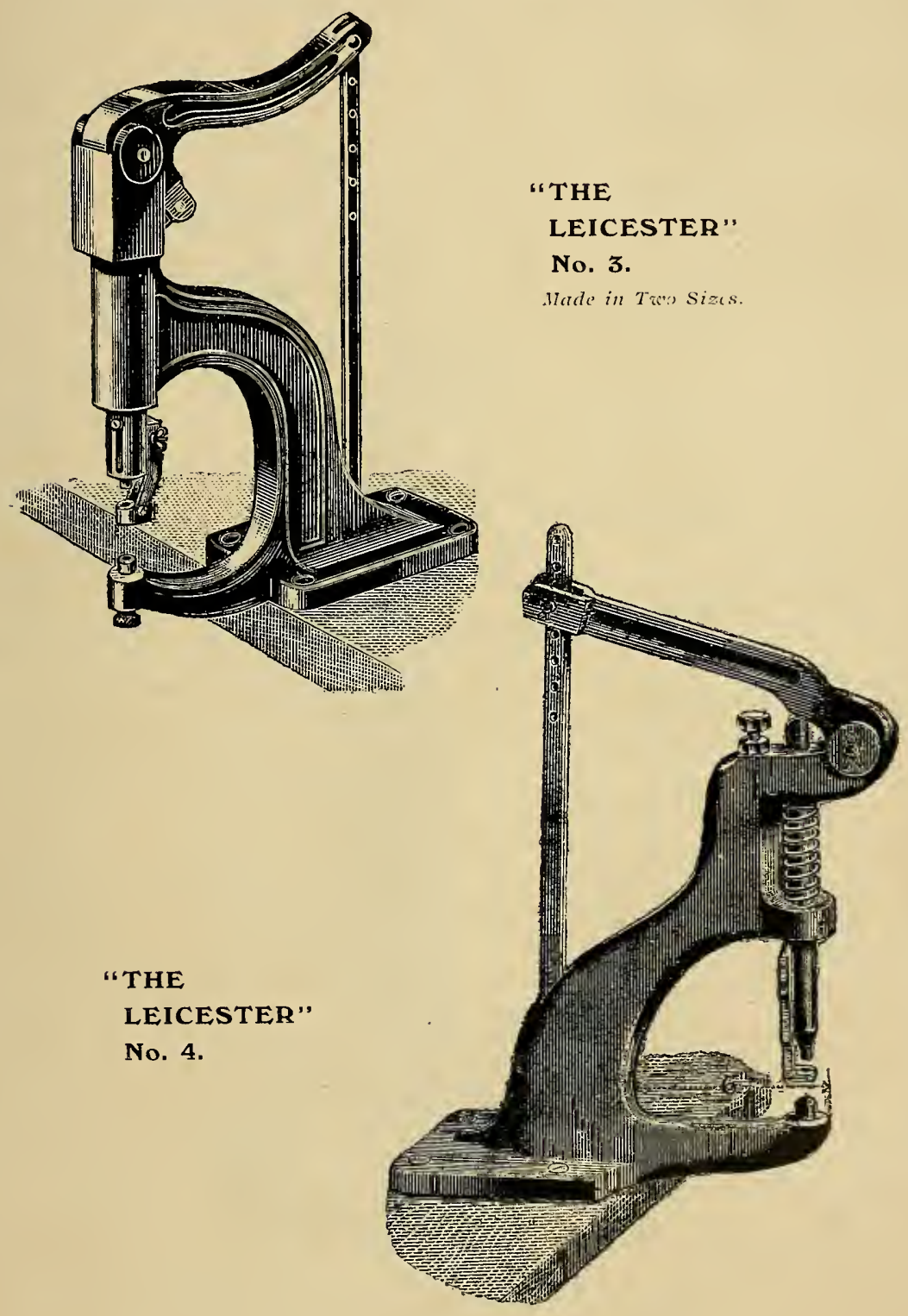

PRICES OF MACHINES ON APPLICATION. 


\section{The Leicester Self-Feeding Machine.}

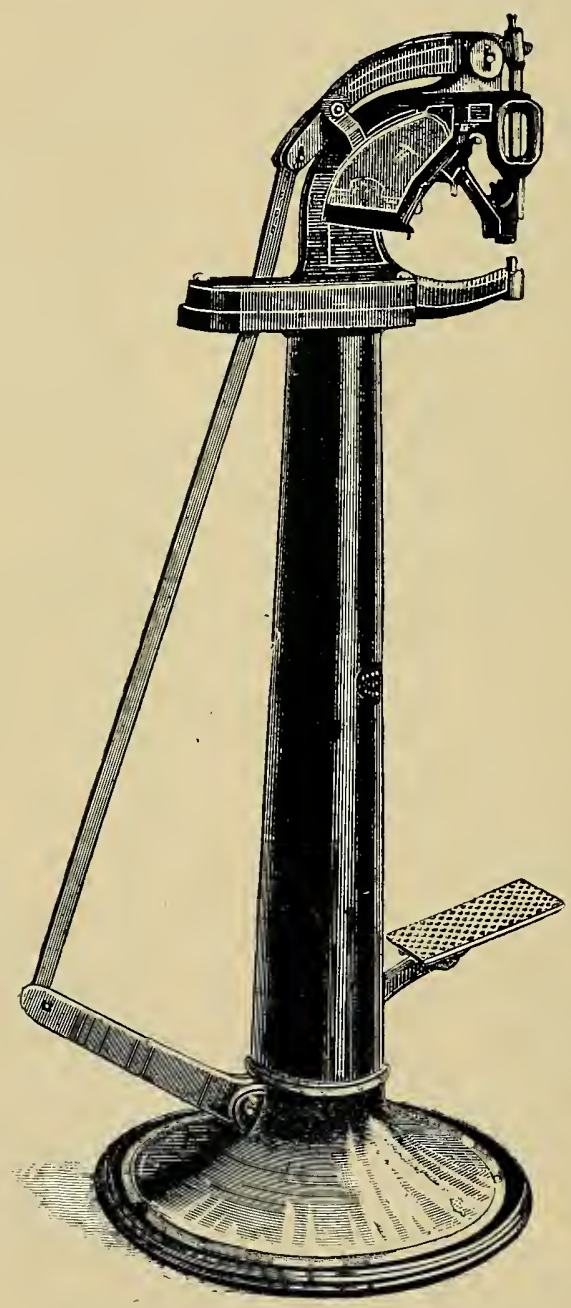

PRice of THIS Machine on application. 

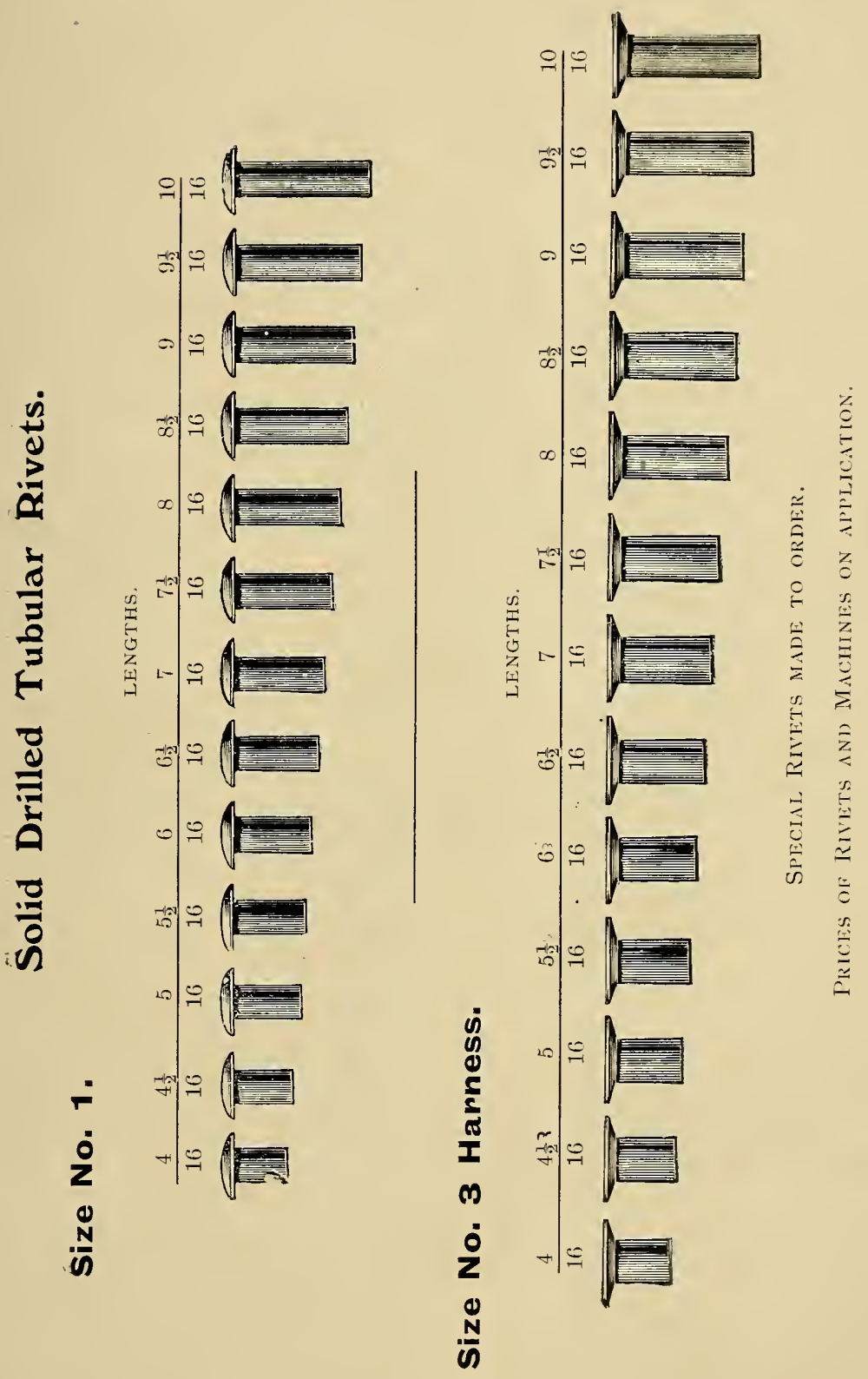


\section{Tubular Rivets (Split).}

With Flat, Oval and Mushroom Heads, - MADE IN -

\section{STEEL, BRASS and COPPER,}

and may be had in Four Colours.

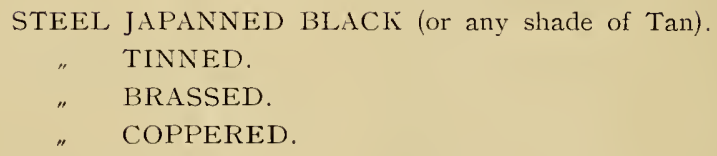

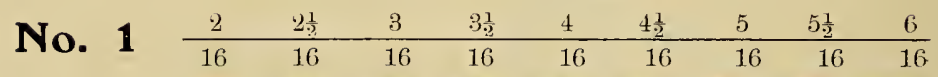

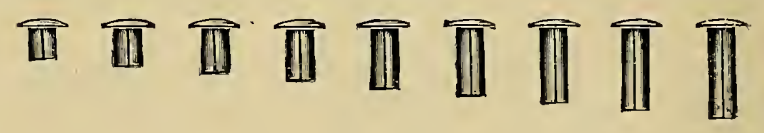

SPECIAL Rivets made TO ORDER.

Prices of Rivets and Machines on application. 

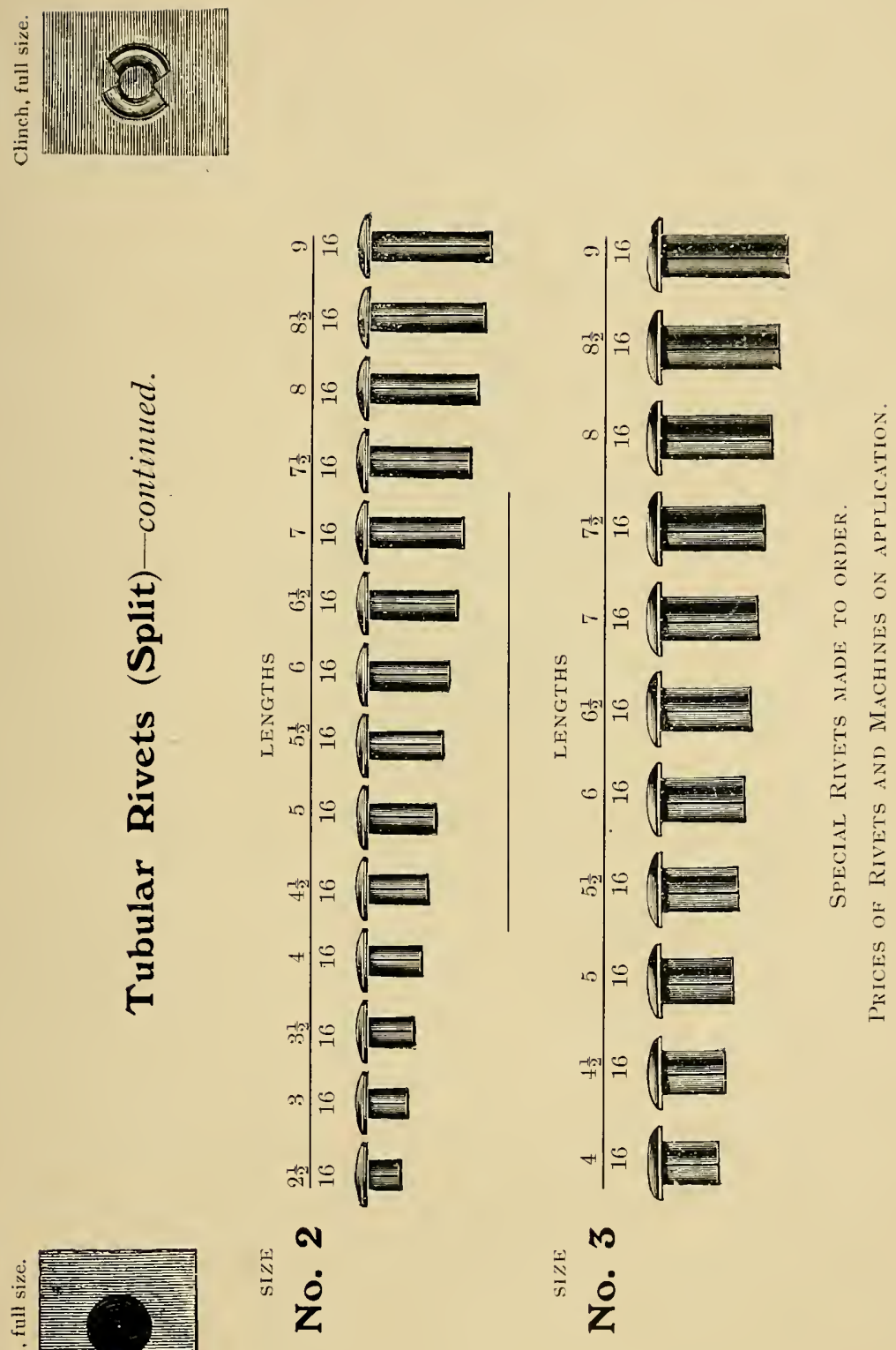


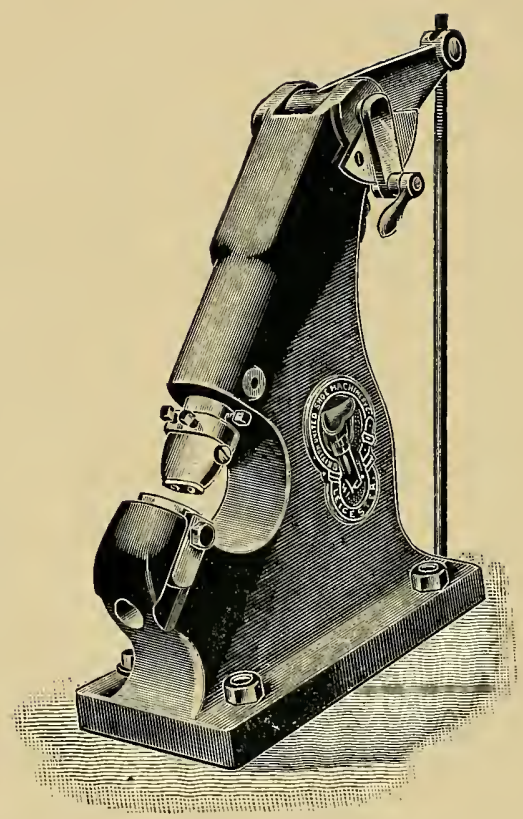

\section{Foot Power Link and Washer Cutting Machine.}

W

HEN power is not available or first cost is a consideration, we recommend the Machine illustrated above, which uses Dies similar to those used with the power Machine, each link or washer being cut complete at each stroke of the treadle.

$\begin{array}{lllllllll}\text { Price with one Die } & \ldots & \ldots & \ldots & \ldots & \$ 10 & 0 & 0\end{array}$

$\begin{array}{llllllll}\text { Extra Dies per set } & \ldots & \ldots & \ldots & \ldots & 2 & 0 & 0\end{array}$

Countersinking Machine for power, to stand on bench... 110

Countersinking Machine on Stand for treadle $\quad \ldots .300$

$\begin{array}{cccc}\text { Net weight. } & \text { Gross weight. } & \text { Bench space. } & \text { Height. } \\ 95 \mathrm{lbs} . & 117 \mathrm{lbs}, & 7^{\prime \prime} \times 15^{\prime \prime} & 18^{\prime \prime}\end{array}$ 


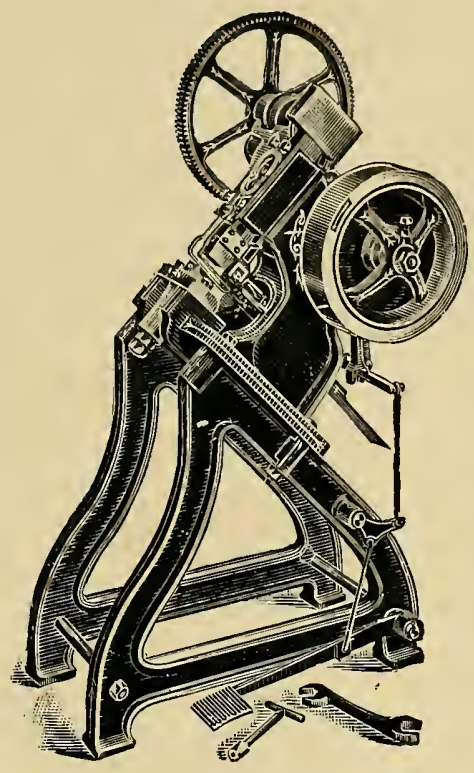

\section{Power Link and Washer Cutter Machine.}

complete link or washer is cut at each stroke of the machine, the link
having two holes in it and the washer being cut on both the inside and outside circumferences. The machine is also used for cutting small strap billets and other shapes of similar size. The largest size of link we recommend the machine to be used for is $3^{\prime \prime}$ long by $1^{\prime \prime}$ wide, or washer, 2 " ontside diameter, and other shapes of similar size.

The material cut by the machine include leather, leather board, asbestos, india rubber, insertion, cloth, \&c.

The links are used for link belting, doormats, \&c., and the washers for many mechanical purposes including watertaps, steam taps, etc. As each part is cut it is automatically ejected from the die and falls clear of the machine.

Price, including one complete die for either a link or washer Extra dies per set

Countersinking machine for power, to stand on bench

Countersinking machine for power, to stand on bench

Countersinking machine on stand, with treadle ...

$$
\begin{aligned}
& \ldots £ 20 \quad 0 \quad 0 \\
& \text {.. } 250 \\
& \text {... } 1100 \\
& \begin{array}{lllll}
\ldots & \ldots & 3 & 0 & 0
\end{array}
\end{aligned}
$$

Receiving pulley $12^{\prime \prime} \mathrm{x} \cdot 2_{4}^{3 \prime \prime}$, runs at 320 revolutions per minute.

$\begin{array}{ccccc}\text { Belt. } & \text { Net weisht. } & \text { Gross weight, } & \text { Floor space. } & \text { Heisht. } \\ 2 \frac{1}{2} & 343 \mathrm{lbs} & 456 \mathrm{lbs} & 19^{\prime \prime} \times 2 \mathrm{~S}^{\prime \prime} & 4 t^{\prime \prime}\end{array}$




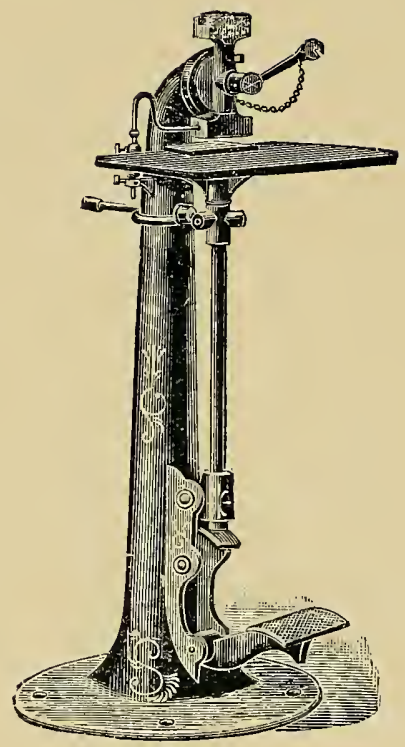

\section{Gold Embossing Machine.}

QOR stamping names or designs in silver or gold on purses, braces, etc. Will work equally well on silk, leather, or cotton.

The machine is made to carry two stamps, either of which can be brought into use instantly.

Stamps to customers' designs are supplied at an extra charge.

Price, without stamps

Net weight.

110 lbs.
Gross weight.
150 lbs.
Length.
$18^{\prime \prime}$

\section{$£ 800$}

$\begin{array}{cc}\text { Width. } & \text { Height. } \\ 18^{\prime \prime} & 48^{\prime \prime}\end{array}$




\section{TESTIMONIALS.}

The Scottish Cooperative Wholesale Society, Ltd.,

The British United Shoe Machinery, Co., Ltd., Glasgow.

Gentlemen, Union Works, Leicester.

Replying to your letter of the 9th, we have much pleasure in stating that the No. 6. Harness Sewing Machine supplied to us September, 1899, and which has been constantly in use in our Saddlery Department every day, doing both light and heavy work, stitching from 7 up to 13 stitches per inch, has given us entire satisfaction.

Our outlay in the way of repairs of parts has been but a small item, when we consider the class of work this machine has to do, frequently necessitating (when a different stitch is required that certain parts have to be unscrewed and then put together again.

Our experience is, that, if well operated, it turns out work equal to the hand, both for neatness and wear.

We also use in this Department the Strap Punching Machine got at the same date, while a Creasing, Trace Trimmer, Trace Burnisher, Lap Skiver, supplied in September, 1901, have all been in constant use, and wrought to our entire satis. faction, repairs having cost us practically nil.

All those in the trade who are not presently in possession of these machines, or who may be contemplating taking them up, we should say that they cannot do better, as from our experience, we have much pleasure in recommending them.

$$
\text { Yours faithfully, }
$$

$$
\text { pro. S.C.W.S., Ltd., }
$$

WILLIAM MILLER,

Manager.

Co.operative Wholesale Society, Ltd., 1 Balloon Street,

Manchester.

The British United Shoe Machinery Co., Ltd.,

Gentlemen, Union Works, Leicester.

We have had your Harness Machinery working on our premises for some years, and have found each separate machine to do its work in an entirely satis. factory manner.

Yours truly,

pro. Co.operative Wholesale Society,

Manchester.

HENRY JACKSON,

Manager.

Co.operative Wholesale Society, Ltd., Saddlery Department,

Darn Crook,

The British United Shoe Machinery Co., Ltd.,

Newcastle.on'Tyne.

\section{Union Works, Leicester.}

In reply to yours of the 25 thth inst., I may say for the last four years we have used your No. 6 and A1 Machines, and Trace Trimmer, etc., which have given us satisfaction in every way.

Yours truly,

1. THOMPSON. 


\section{TESTIMONIALS continued.}

Horse Clothing Manufacturers, Plume Works,

The British United Shoe Machinery Co., Ltd.,

Walsall.

Dear Sirs, Union Works, Leicester.

In reply to your memo. of January 26th, we have half.a.dozen of your No. 6 Machines for the last six years in constant use in our factory, and the work which has been turned out by them has always been most satisfactory, and we should not replace them by any other machine.

Faithfully yours.

D. POWER $\circledast$ SONS.

R. E. Thacker,

Wholesale Saddlers' Manufacturers, Walsall.

We have used Messrs. The British United Shoe Machinery Company's No. 6 and A1 Machines for a number of years, and have found them entirely satisfactory.

R. E. THACKER.

The British United Shoe Machinery Co., Ltd.,

18 Green Lane, Walsall. Union Works, Leicester.

We have the used No. 6 and the A1 Machines for a number of years, and we have found them very satisfactory.

THE LIGGINS CO., LTD.

\section{Queen's Hotel Buildings,}

Nethergate,

The British United Shoe Machinery Co., Ltd.,

Dundee.

Dear Sirs, Union Works, Leicester.

It is now over five years since you sent me your No. 6 Machine. I have used it regularly, and during all that time it has given me the utmost satisfaction, and I have not the slightest hesitation in recommending it to my brother trades. men as a great saver of time and labour. It is a very handy iron man to have in your shop. He is always there and ready, and can do all sorts of stitching, from patent leather winkers, 14 stitches to the inch with three cord thread, to heavy mill belting, 6 stitches to the inch with eight cord thread. I don't know what I should do without it, I consider it paid itself the first year.

You are quite at liberty to use this letter, as I am certain that it is the most practical machine for general saddlery for producing good work at a great re. duction of labour.

$$
\begin{aligned}
& \text { I am, } \\
& \text { Yours faithfully, } \\
& \text { W. T. REID. }
\end{aligned}
$$

The British United Shoe Machinery Co., Ltd.,

22 High Street, Leicester.

Dear Sirs,

I have now had your No. 6 Machine in use for the past five years, and the work done by it has proved quite satisfactory.

JOHN KEIR. 


\section{INDEX.}

Amazeen Skivins Machine

Atmospheric Gas Heater
PAGF:

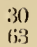

fi.3

Belt Splicinss and I, eather Splittins Machine 20 Bevellin: Machine

blind or Winker Moulds

Block Planins Attachment-Ideat

Burnishing Machine, Trace

67

12

61

Circular Press Blocks

Clicking Press, No. 3, Icleal

18

Creasins Machimes

6,57,

Cutters

Cuttins Boards, Hand

Cuttins Machine, Strap

Cutting Press. No. 2. Rapid

Dock Forming and Stretchin« Machine Dock Stuffing Machine..

Edse Settins Machine, Rotary Bench Embossing Machine, Gold

Eyletting Machines

$20,21,22$

$34,3.5$

Four Pillar Box Bed Presses

15

Gas Heater, Atmospheric

Gold Embossing Machine

Hand Cutting Boards

Harness Loop Creasing Outfit..

Harness Loop Dies

Hose Pipe Punching Machine

Ideal Block Planing Attachment

Ideal Clicking Press, No. 3

lnking Brush

10, 11

Knives

$20,21,22$

Lap Skiving Machine. Osborne's

Leather Measuring Machine

Leather Rollers

Link and Washer Cutting Machine

Loop Creasing Outfit

Loop Dies

19
65.66

33

Pewing Machine

PAgE:

Planins Attachment, lileal Block

Press, la

Press Blocks

Presses, Four Pillar, 13ox Bed

Press, Massic

Press, No. 3, Icleal Clicking

Press, No. 2, Ratjid Cuttints

resses, Revolution

Punches

Punching Machines, Eyelet

Punchins Machine, Hosepipe

Punching Machine, Strat)

Ransing Machines

Rapid Cuttins Press, No. 2

Rawhide Mallets

Revolution Presses

Rivettins Machines

Rivets and Studs

Rolling Machines

Rolls Slickins

Rotary Bench Edge Setting Machine

48,49

- 12

11

17. 18

15

io. 11

(1)

$20,21,2$

70
$3: 3$

Seam Finishing Machine, Union

Sectional Press Blocks ....

59

Self Feeding Eveletting Machine 71

Sewing Machine, A.1.

37

, " $\quad$ No.

" $\quad$ " No. No 2

$38,40,41$

" . No. 2Trunk \& Bag Makers' 42

" . No. 4 Leather Belt ... 43, 41

". $\quad$. No. $6 \ldots \ldots$.... 44, 45, 46, 47

Pilot $\ldots . . . . \quad \ldots . \quad 48,49$

,... $27,30, \cdots, 36$

Slicking Rolls

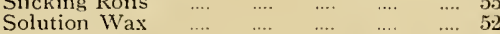

Spare Parts

Splitting Machines $\quad 23,24,25,26,29$

Splicing Machines $\quad \ldots . \quad \ldots . . . .27,28,29$

Standard Rivetting Machines .... 73

Standard Rivets and Studs $\quad 74.75$

Stitching Horse ....

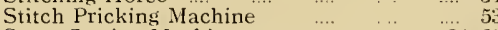

Strap Cutting Machine ... ... ... $34,3.5$

Strap Punching Machine 3

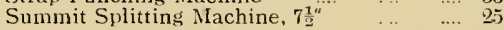

Terms 3

$\begin{array}{llllllll}\text { Thread } & \ldots & \ldots & \ldots & \ldots & \ldots & \ldots & \ldots \\ \end{array}$

Trace Burnishing Machine $\quad$.... $\quad \ldots \quad . \quad$... 61

Trace Trimming Machine _... …79, 70.81

$\begin{array}{llll}\text { Tubular Rivets } & \ldots . . & \ldots & 79,80.81 \\ \text { Tubular Rivetting Machines } & \ldots . . & \ldots . & 76,77,78\end{array}$

Masic Press

IIalletts, Rawhide

Marvel Skiving Machine. Over-arm … $\quad \ldots . .31$

Measuring Machine, Leather ....

Needles

New Model Splitting Machine

Union Seam Finishing Machine

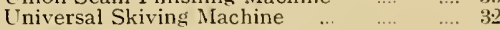

Veining Machines.... ....

Wax Thread Sewing Machines

$37,38,39,40,41,42,43,44,45,46,47,45,49$

IVax ....

Winker or Blind Moulds 

Oor Gooda ean the obtained from the

\section{followins Companies:}

os.rikaHI.

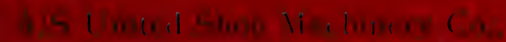

I in 1,1, , II: in 11 ,

CRANCE.

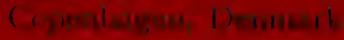

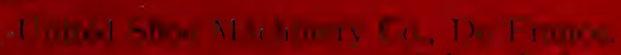

AUSTUNLIA.

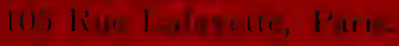

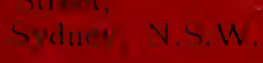

AUST WALIA.

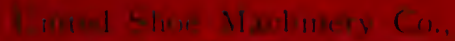

181 Ihfi linu, Ih Stin:

GERMANY.

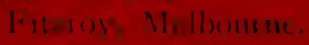

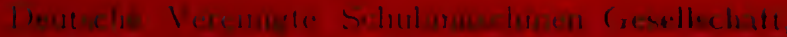

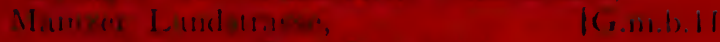

$$
\begin{aligned}
& \text { l I.ullint, I M. }
\end{aligned}
$$

ITALY

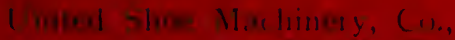

$$
\text { i) (th thifentin, }
$$

SOUTH AMERICA.

Miln.

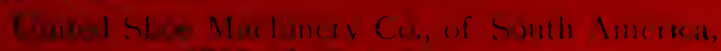

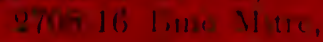

spoir.

$$
\text { Bun In, Silli Amered }
$$

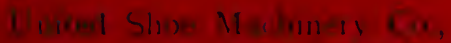

$$
\begin{aligned}
& \operatorname{Sin} 11=1 \mathrm{~J}, 1 / 1,1, \\
& \text {, (a) I, I ortumy, }
\end{aligned}
$$

SWTTZERLAND.

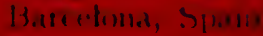

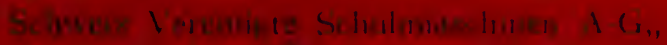

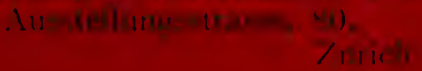

I. S.N.

I ath I Slice Maburar (e.

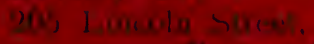

TE.W ZEAL.AND.

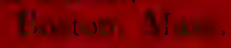

11. (). Hewetl is (n.

CANADA.

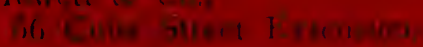

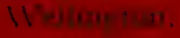

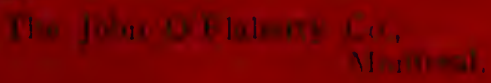




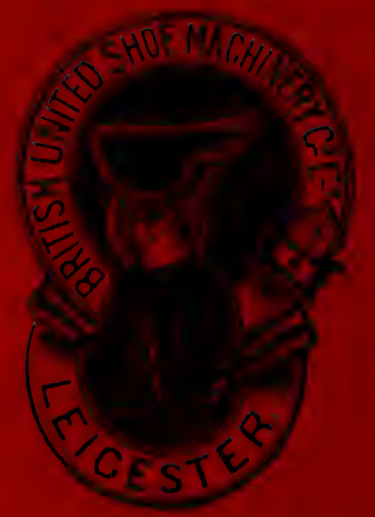

